c. 3

US Army Corps of Engineers

Waterways Experiment Station

\title{
Debris Control at Hydraulic Structures in Selected Areas of the United States and Europe
}

by N. Wallerstein, C. R. Thorne, University of Nottingham

S. R. Abt, Colorado State University

\section{US-CE-C Property of the}

United States Government 
$3^{9^{12^{20^{6}}}}$

\title{
Debris Control at Hydraulic Structures in Selected Areas of the United States and Europe
}

\author{
by N. Wallerstein, C. R. Thorne \\ Department of Geography \\ University of Nottingham \\ Nottingham, England \\ S. R. Abt \\ Engineering Research Center \\ Colorado State University \\ Fort Collins, CO
}

Final report

Approved for public release; distribution is unlimited

Prepared for U.S. Army Research Development \& Standardization Group - UK London, England

Under Contract No. N68171-95-C-9133

Project No. WK2Q5C-7793-EN01 


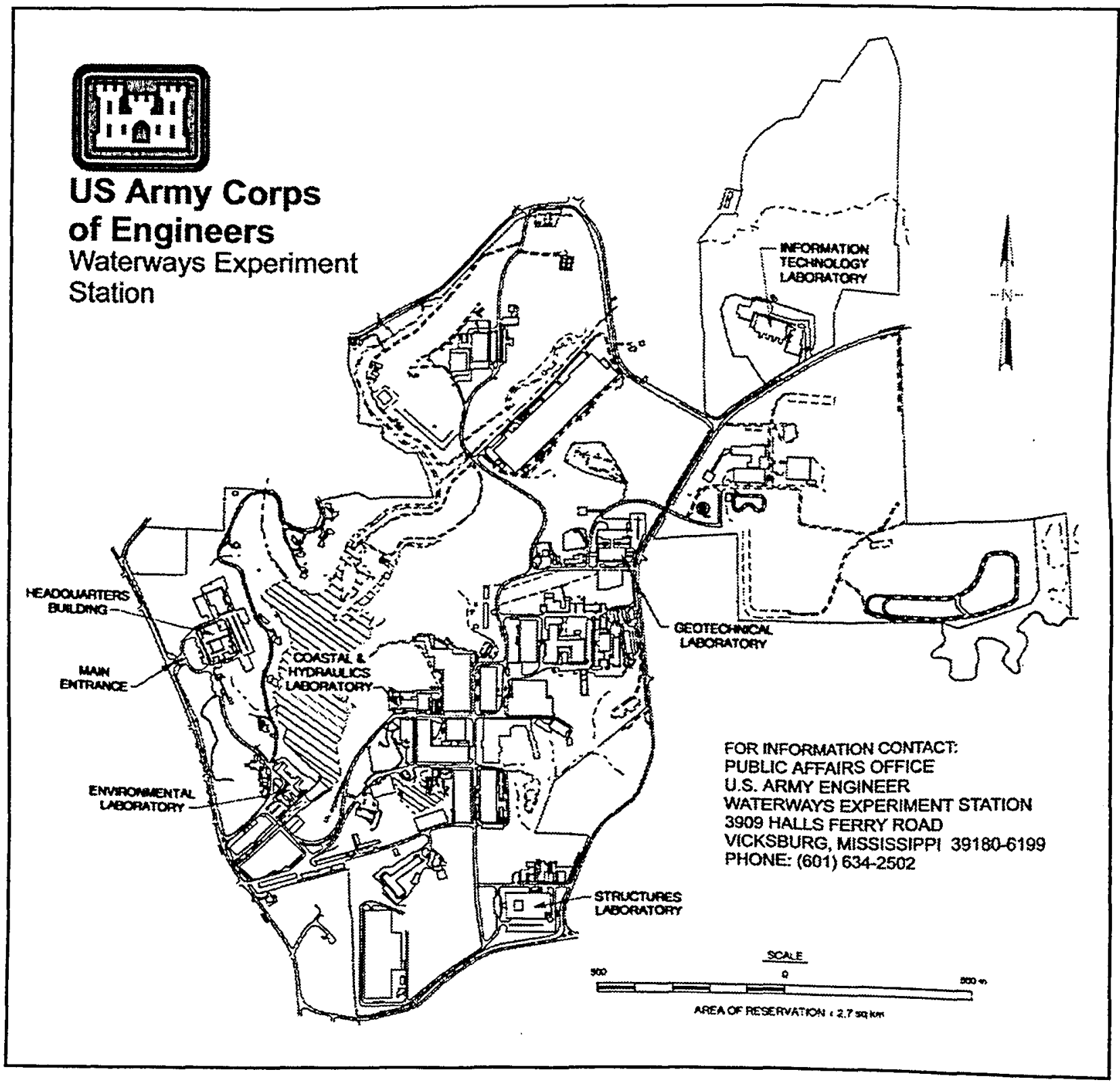

\section{Waterways Experiment Station Cataloging-in-Publication Data}

Wallerstein, $\mathrm{N}$.

Debris control at hydraulic structures in selected areas of the United States and Europe / by N. Wallerstein, C.R. Thome, S.R. Abt ; prepared for U.S. Army Research Development \& Standardization Group-UK ; monitored by U.S. Army Engineer Waterways Experiment Station.

122 p. : ill. ; $28 \mathrm{~cm}$. - (Contract report ; CHL-97-4)

Includes bibliographic references.

1. Reversible flow trashracks - Management. 2. Trashracks - Management. 3. Hydraulic structures. I. Thorne, C. R. (Colin R.) II. Abt, Steven R. III. United States. Army. Corps of Engineers. IV. U.S. Army Engineer Waterways Experiment Station. V. Coastal and Hydraulics Laboratory (U.S. Army Engineer Waterways Experiment Station) VI. United States. Army. Research, Development, and Standardization Group (U.K.) VII. Title. VIII. Series: Contract report (U.S. Army Engineer Waterways Experiment Station); CHL-97-4.

TA7 W34C no.CHL-97-4 


\section{CONTENTS}

LIST OF FIGURES vi vi

LIST OF PLATES vii

PREFACE viii

UNITS OF MEASUREMENT $\quad x$

SUMMARY

$\begin{array}{lr}\text { INTRODUCTION } & 1\end{array}$

CHAPTER ONE : DEBRIS CONTROL HYDRAULIC STRUCTURES

IN SELECTED AREAS OF EUROPE $\quad 5$

1.1 Location Map $\quad 5$

1.2 "Treibholzfange" Debris Retention Device 6

1.3 Debris Retention Basins for Torrent Control 13

1.4 Diversion Tunnel : Campo Vallemaggia 14

1.5 Debris Problems at Spillways : The Palagnedra Dam 15

1.6 Spillway Design with Debris Retention Devices $\quad 18$

$\begin{array}{ll}1.7 \text { Bremgarten-Zufikon Powerplant (Switzerland) } & 20\end{array}$

CHAPTER TWO : DEBRIS CONTROL AT HYDRAULIC STRUCTURES

IN SELECTED AREAS OF THE UNITED STATES 22

$\begin{array}{ll}2.1 \text { Location Map } & 22\end{array}$

2.2 Huntington District $\quad 23$

2.3 Vicksburg District $\quad 25$

2.3.1 Columbia Lock and Dam 26

2.3.2 Jonesville Lock and Dam 27

2.3.3 J. H. Overton Lock and Dam 27

$\begin{array}{ll}2.3 .4 \text { Summary } & 28\end{array}$

2.4 St. Louis District $\quad 28$

2.5 Louisville District $\quad 29$

$\begin{array}{ll}2.5 .1 \text { Reservoir Operations } & 29\end{array}$ 
2.5.2 Lock and Dam Operations

2.6 Drift Management at Bluestone Dam 31

2.7 Clover Fork Tunnel Diversion Project 34

2.8 Portland District 37

2.8.1 Bonneville Dam 37

$\begin{array}{ll}\text { 2.8.2 High Head Dams } & 38\end{array}$

2.9 San Francisco District $\quad 38$

$\begin{array}{ll}2.10 \text { Summary } & 39\end{array}$

CHAPTER THREE : DEBRIS CONTROL SYSTEMS

3.1 Debris Retention Devices $\quad 41$

3.2 Trash Racks $\quad 42$

3.2.1 Constructional Features of Trash Racks 43

3.2.2 Vortices at Hydro-Plant Intakes $\quad 48$

3.2.3 Vibration Problems at Trash Racks 49

3.3 Removing Floating Debris $\quad 52$

3.3.1 Unguided Mechanical Rakes $\quad 52$

3.3.2 Guided Mechanical Rakes $\quad 53$

$\begin{array}{ll}3.4 \text { Debris Passage } & 57\end{array}$

3.5 Disposing of Debris $\quad 57$

$\begin{array}{ll}\text { 3.6 Debris Passage at Spillways } & 58\end{array}$

3.6.1 Recommended Practice to Prevent Obstruction 58

$\begin{array}{ll}\text { 3.6.2 Theoretical Research } & 58\end{array}$

$\begin{array}{ll}\text { 3.7 Thermal Power Plant Trash Screens } & 61\end{array}$

CHAPTER FOUR : CONCLUSIONS \& RECOMMENDATIONS 64

$\begin{array}{ll}4.1 \text { Conclusions } & 64\end{array}$

4.1.1 In-channel debris retention devices $\quad 64$

4.1.2 Flow Diversion Tunnels $\quad 64$

4.1.3 Lock and Dam Structures $\quad 65$

4.1.4 Spillways $\quad 65$ 
4.1.5 Power Plant Intakes $\quad 66$

$\begin{array}{ll}\text { 4.1.6 Raking Devices } & 67\end{array}$

$\begin{array}{ll}\text { 4.1.7 Debris Disposal } & 68\end{array}$

$\begin{array}{ll}4.2 \text { Recommendations } & 68\end{array}$

$\begin{array}{lr}\text { REFERENCES } & 72\end{array}$

APPENDICES

$\begin{array}{ll}\text { A US and European Contacts } & 75\end{array}$

$\begin{array}{ll}\text { B Bluestone Lake - Drift Work } & 77\end{array}$

C Bluestone Dam - photographs $\quad 83$

D Black River - photographs $\quad 84$

E Lock and Dam Operation - photographs

F Markland Locks \& Dam $\quad 87$

G Debris Accumulation at Ohio River Lock Intakes $\quad 89$

H Columbia River Power Complex $\quad 97$

I San Francisco Bay Area of Operation $\quad 98$

$\begin{array}{ll}\text { J Debris Boat Technical Description } & 100\end{array}$

$\begin{array}{ll}\text { K Photographs } & 103\end{array}$

SF298 


\section{LIST OF FIGURES}

1.1 European Location Map 5

$\begin{array}{ll}1.2 \text { Tested flume post alignments. Modified from Knauss (1985) } & 8\end{array}$

1.3 Planform views of model set-up for Lainbach and Arzbach debris $\begin{array}{ll}\text { retention devices (after Knuass, 1985) } & 11\end{array}$

1.4 Construction details of posts and foundations on Lainbach Treibholzfang (modified from Knauss, 1985) 11

1.5 Design plans for Arzbach Treibholzfang (modified from Knauss, 1985) 12

$\begin{array}{ll}\text { 1.6 Debris retention basin with woody debris protection device } & 13\end{array}$

$\begin{array}{ll}1.7 \text { Schematic diagram of the Campo Vallemaggia diversion tunnel } & 14\end{array}$

1.8 Structural details of the spillway for the Sylvenstein Dam

$\begin{array}{ll}\text { (from Knauss, 1985) } & 18\end{array}$

1.9 Run-of-river turbine with separation layer and currentless zone

$\begin{array}{ll}\text { (longitudinal section). Modified from Bisaz et al. (1976) } & 21\end{array}$

1.10 Position of Injector shaft at turbine intake. Modified from Bisaz et al. (1976) 21

2.1 United States Location Map 22

2.2 Bluestone Dam proposed intake structure (from Fripp et al., 1996) 33

2.3a Type 6 design approach (from Martin, 1989) 36

2.3b Type 7 design approach (from Martin, 1989) 36

3.1 Double-log log boom $\quad 42$

3.2 Variables and K factor values for various bar shapes (modified from Zowski, 1960) 45

3.3 Trash rack bar variables (modified from Osborn (1968) 47

3.4 Details of trash racks which failed during operation (modified from

Syamalarao, 1989)

3.5a Trash rakes for thermal power plants (a) unguided, (b) guided

(from Richards, 1988)

3.5b Through-flow travelling screens (from Richards, 1988) 


\section{LIST OF PLATES}

1 Physical model of Lainbach "Treibholzfang" with debris and sediment load. View downstream

2 Physical model of the Arzbach "Treibholzfang". Note the central low flow channel and stilling basin. View upstream

3 Treibholzfang device on the River Lainbach. View downstream

4 Treibholzfang on the River Lainbach. Sediment removal operation. View upstream

5 Palagnedra dam prior to remodelling of spillway (after Vischer \& Trucco, 1985)

6 Dam choked with debris on the morning of August 8th, 1978 (after Vischer \& Trucco, 1985)

7 Physical model (scale 1:50) with remodelled spillway. Discharge

$2.2 \mathrm{~m}^{3} / \mathrm{s}$ (after Vischer \& Trucco, 1985)

8 Fixed pillar-interceptor with service bridge (after Hartung \&

Knauss, 1976)

9 Model of new Sylvenstein Dam spillway with debris retention device

10 Clover Fork Tunnel model, original design approach (from Martin, 1989)

11 Test run using Standard Project Flood and debris load (from Martin, 1989)

12 Leonard type rake with combined hoist, trash car and apron (after Zowski, 1960)

13 Plow rake installation (after Zowski, 1960)

14 Newport News mechanical guided trashrack rake (after Zowski, 1960) 


\section{PREFACE}

This report reviews current debris management technologies that are employed at various run-ofriver structures in Europe and the United States. The information reported has been obtained through field visits and from discussions with engineers and plant operators during September 1995-October 1996. Relevant published research work on debris control mechanisms, including trash rack design problems, raking equipment, and spillway design is also reviewed. This review was conducted by personnel of the Department of Geography, University of Nottingham, Nottingham, England; the Engineering Research Center, Colorado State University, Fort Collins, Colorado; and the Hydraulics Laboratory (HL), U.S. Army Engineer Waterways Experiment Station (WES), Vicksburg, MS. The study was sponsored by the U.S. Army Research Development and Standardization Group - UK, London, under contract number N68171-95-C-9133.

This report was prepared by Dr. Nick Wallerstein and Dr. Colin Thorne, Department of Geography, University of Nottingham, Nottingham, England, and Dr. Steve Abt, Engineering Research Center, Colorado State University, Fort Collins, Colorado, and coordinated through Dr. Frank M. Neilson, Spillways and Channels Branch, HL, WES.

The study was performed under the direction of Messrs. Frank A. Herrmann, Jr., Director, HL, and R. A. Sager, Assistant Director, HL; Dr. Phil Combs, Chief, Rivers and Structures Division, $\mathrm{HL}$; and Mr. Bobby Fletcher, Chief, Spillways and Channels Branch, HL.

This report is being published by the WES Coastal and Hydraulics Laboratory (CHL). The CHL was formed in October 1996 with the merger of the WES Coastal Engineering Research Center and Hydraulics Laboratory. Dr. James R. Houston is the Director of the CHL and Mr. Charles C. Calhoun, Jr., is Assistant Director.

Special thanks go to Messrs. J. J. van der Zwaard, Henk Verheij, and Hermjan Barneveld, Delft Hydraulics; Professor Jost Knauss, Director of the Hydraulics Laboratory of the Technical University of Munich, Germany; and Dr. A. Chervet, Director of the Hydraulics, Hydrology and Glaciology Institute at the Technical University of Zurich, Switzerland, for their assistance and cooperation with this research effort and for hosting visits to their institutes, giving of their time for discussions, and making their research work and papers freely accessible. Additional thanks go to 
Dr. Andreas Keller and family for their generous hospitality and friendship during research in Bavaria and to Mr. Chris Pater for an excellent driving performance during European travel and good humor throughout the trip.

Ms. Deborah R. Cooper, Spillways and Channels Branch, CHL, is acknowledged for coordinating publication of this report during the illness and after the death of Dr. Frank M. Neilson.

At the time of publication of this report, Director of WES was Dr. Robert W. Whalin. Commander was COL Robin R. Cababa, EN. 


\section{UNITS OF MEASUREMENT}

Units of measurement used in this report can be converted as follows:

\begin{tabular}{ccc} 
To convert & To & Multiply by \\
\hline inches (in) & millimetres $(\mathrm{mm})$ & 25.4 \\
feet (ft) & meters $(\mathrm{m})$ & 0.305 \\
yards (yd) & meters $(\mathrm{m})$ & 0.914 \\
miles (miles) & kilometers $(\mathrm{km})$ & 1.61 \\
feet per second (ft/sec) & meters per second $(\mathrm{m} / \mathrm{sec})$ & 0.305 \\
square feet (sq ft) & square meters $\left(\mathrm{m}^{2}\right)$ & 0.093 \\
square yards (sq yd) & square meters $\left(\mathrm{m}^{2}\right)$ & 0.836 \\
square miles (sq miles) & square kilometers $\left(\mathrm{km}^{2}\right)$ & 2.59 \\
acres (acre) & hectares $(\mathrm{ha})$ & 0.405 \\
acres (acre) & square miles $\left(\mathrm{m}^{2}\right)$ & 4050 \\
cubic feet (cu ft) & cubic meters $\left(\mathrm{m}^{3}\right)$ & 0.0283 \\
cubic yards (cu yd) & cubic meters $\left(\mathrm{m}^{3}\right)$ & 0.765 \\
cubic feet per second (cfs) & cubic meters per second $(\mathrm{cms})$ & 0.0283 \\
pounds (lb) mass & kilograms $(\mathrm{kg})$ & 0.453 \\
tons (ton) mass & kilograms $(\mathrm{kg})$ & 907 \\
pounds force $(\mathrm{lbf})$ & newtons $(\mathrm{N})$ & 4.45 \\
kilogram force $(\mathrm{kgf})$ & newtons $(\mathrm{N})$ & 9.81 \\
acre-feet (acre-ft) & cubic metres $\left(\mathrm{m}^{3}\right)$ & 1230
\end{tabular}




\section{SUMMARY}

Floating debris obstruction is a problem at many run-of-river structures including navigation locks, hydro-electric and thermal-electric power plants and dam spillways.

Previous research suggests that a sound understanding of debris sources, input mechanisms, and budgets within the relevant catchment would aid with developing more cost-effective debris control methods. Conventional systems such as log-booms and trash racks involve considerable capital cost, can be expensive to maintain, and may themselves prevent optimal operation of the structure they protect.

The European research centers visited were Delft Hydraulics in The Netherlands, the Hydraulics Laboratory at the Technical University of Munich, Germany, and the Institute of Hydraulics, Hydrology and Glaciology at the Technical University of Zurich, Switzerland. The U.S. field visits were carried out in the western, eastern, central and south-central United States in the Portland, San Francisco, Huntington, Vicksburg, St. Louis, and Louisville Districts of the U.S. Army Corps of Engineers.

The control technologies are summarized and state-of-the-art design procedures and best practice management recommendations for debris control are outlined for each class of structure that may experience debris build-up problems. 


\section{INTRODUCTION}

Floating debris can create severe problems for a variety of structures and water based activities. Debris can destroy the propellers of recreational and commercial boats and cause damage to boat hulls. Navigation lock operation can be impaired by debris caught on a gate sill. Floating debris has the greatest economic effect on users of large quantities of water such as hydro-electric and thermalelectric generating plants and municipal water systems. On occasion dam gates can become stuck partly open by debris intrusion and severe downstream bed scour may occur. Floating debris can also damage the upstream slopes of dams through wave action which hammers debris against the dam wall and other structures.

In order to develop improved and more cost-effective debris control systems it would be beneficial to have a sound understanding of debris dynamics within the relevant catchment area, upstream of that structure. Basin-wide studies can help engineers to make more informed decisions on debris management and to design better measures for counteracting debris damage and disruption at structures. This is a topic of on-going research at the University of Nottingham (Wallerstein \& Thorne 1994 and 1995). However, even with the most efficient catchment management measures, some debris will always arrive at structures and plant operators must, therefore employ design features or install devices to prevent floating debris from entering and damaging turbines, valves, gates, and pumps.

Debris control and exclusion systems involve considerable capital cost, and difficult and expensive maintenance procedures and they may themselves impair the efficient operation of the structure they were intended to protect. For example, trashracks at hydro-electric power plant intakes cause head loss so that bar spacing requirements to prevent debris entry into the turbines must be balanced against the loss of potential energy for power generation.

It is apparent that considerable scope exists for a review of the various debris management systems employed at different hydraulic structures, particularly in European waterways where there are some sophisticated solutions that could be usefully applied within the USA.

The first chapter in this report documents the findings from a two week field visit carried out between $11^{\text {th }}$ and $20^{\text {th }}$ October 1995 , by the first author. Several structures and three major hydraulic 
research centres were visited, including Delft Hydraulics, Netherlands; The Hydraulics Laboratory at the Technical University of Munich, Germany; and, The Institute of Hydraulics, Hydrology and Glaciology at the Technical University of Zurich, Switzerland (figure 1.1).

The European site visits were performed as follows:

Location

Dates

Point of contact

Delft Hydraulics, Rivers, navigation 12 Oct. 95

Dr J. J. van der Zwaard

and structures division

Henk Verheij

The Netherlands

Herman Barneveld

Technical University of Munich,

16 Oct. 1995

Prof. J. Knauss

Hydraulics Laboratory,

Obernach, Germany

Technical University of Zurich,

18 Oct. 1995

Dr. A. Chervet

Institute of Hydraulics, Hydrology

\& Glaciology, Switzerland

The second chapter documents field visits and interviews that have been carried out, in Westem Eastern, Central and South-Central USA, by the third author to investigate some of the means and methods that are employed in the management of debris and drift in navigable waterways in the USA.

The US site visits were performed as follows:

$\begin{array}{llll}\text { Corps District } & \text { Location } & \text { Dates } & \text { Primary Contact } \\ \text { Huntington } & \text { Huntington, WV } & \text { 5 SEP 95 } & \text { Mr. Jon Fripp } \\ \text { Vicksburg } & \text { Monroe, LA } & \text { 17 OCT 95 } & \text { Mr. C. L. Corken } \\ \text { St. Louis } & \text { St. Louis, MO } & \text { 8 NOV 95 } & \text { Mr. Billy Arthur } \\ \text { Louisville } & \text { Louisville, KY } & \text { 9 NOV 95 } & \text { Mr.Gene Allsmiller } \\ \text { Portland } & \text { Portland, OR } & \text { 16 JUL 96 } & \text { Mr. Robert van der Borg } \\ \text { San Francisco } & \text { San Francisco, CA } & \text { 2 OCT 96 } & \text { Mr. John Azeveda }\end{array}$

A comprehensive list of contact names and addresses for both Europe and US is presented in Appendix A. 
Chapter two also discusses two other studies that have been carried out in the USA. The first, by Fripp et al. (1996), outlines modifications to the Bluestone Dam on the New River, West Virginia, to allow high flow passage of debris in order to mitigate debris induced recreation and environmental problems downstream. The second, by Martin (1989), documents a physical model test of tunnel entrances on the Clover Fork tunnel diversion project, near Harlan, Kentucky, to determine the best entrance configuration for floating debris passage and optimum hydrodynamic conditions.

In chapter three theoretical research into debris control at dams is considered including debris retention devices, trashracks and spillway design.

Finally, chapter four summarises the design procedures utilised in Europe and the USA and the theoretical work that has been documented and outlines a set of recommendations for state-of-the-art debris control at run-of-river structures.

Before examining the various technologies used to combat floating debris problems at structures it is worth listing the major mechanisms by which debris enters water courses:

\section{a) Wind and wave action}

On lakes and large rivers waves erode the shoreline causing trees to topple into the water. Structures such as docks can be damaged by waves, and much of the flotsam generated remains in the water. Wind and wave action can also cause the removal of debris from natural storage areas such as bays and coves. Wind throw is a major source of debris input in streams in forested areas and wind has also been known to carry appreciable quantities of sagebrush and tumbleweed into rivers in the western USA.

\section{b) Ice Break-up}

Moving ice in the spring break-up can increase the undercutting of riverbanks, and trees can be damaged and broken by the force of moving ice. Ice storms can cause tree limbs and sections of trunks to break off and fall into lakes and watercourses.

\section{c) Forest Litter}

A larger litter input is derived from leaves from deciduous trees and some conifers. Forest litter is usually protected by the tree canopy during summer and by a snow layer in the winter, however in early spring trees are without leaves and heavy rains will wash the litter into watercourses. 


\section{e) Forestry Practices}

Forest lands soak up large quantities of water and reduce floods and erosion that bring floating debris to the streams and rivers. If a generous ground cover is maintained during tree harvest and roads are made erosion resistant, forest land can still protect the watershed. The harvest of trees on a reasonable schedule will reduce the number of dead trees that may fall into the streams and rivers. However, poor harvesting strategies can generate large inputs of debris to streams and rivers.

\section{f) Debris Jams}

Debris jams may release debris downstream when moved en-mass by a large flood flow or when broken down over a long period of time by natural effects such as decomposition.

\section{g) Beaver Dams}

The quantity of debris brought into streams by beavers is unknown, but may be a substantial proportion of the total debris load in some watersheds.

\section{h) Man-made Materials}

This includes decaying wooden structures such as piers and wharves, and organic and synthetic material from dumps improperly located along water bodies, and general littering of trash and waste. 


\section{DEBRIS CONTROL AT HYDRAULIC STRUCTURES}

IN SELECTED AREAS OF EUROPE

\subsection{Location Map}

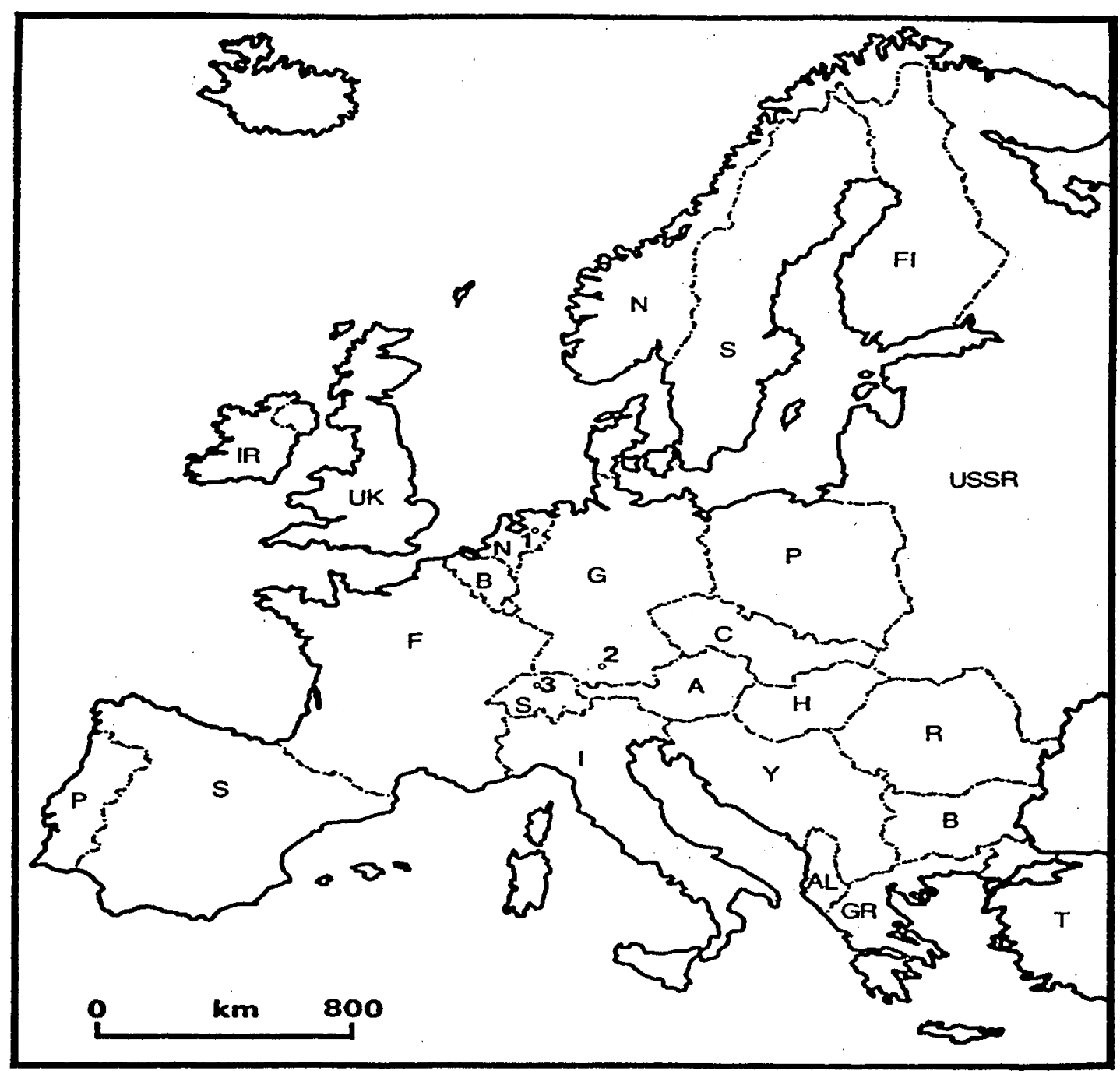

1 : Delft Hydraulica, Emmeloord

2 : Hydraulies Laboratory, Technical, University of Munich, Obernach

3 : Hydraulics, Hydrology, Glaciology Institute, University of Zurich, Zarich
UK : United Kingdom
IR : Republic of Ireland
N : The Netherlands
B : Belgium
F : France
$P$ : Poland
SP : Spain
A : Austria
P : Portugal
H : Hungary
$G$ : Fed Rep of Germany
$Y$ : former $Y$
B : Bulgaria
C : Czech Republic
I : Italy
R: Romania
GR : Greece
T : Turkey
AL : Albania 


\section{2 "Treibholzfange" Debris Retention Device}

The following information was obtained from discussions with Dr J. Knauss at the Institute of Hydraulics, Technical University of Munich, and from a compilation of research papers by Dr. Knauss (Knauss, 1985).

Woody debris input into river channels in the Bavarian Alps is mainly due to landsliding on steep, saturated slopes during and immediately after storm events. The problem is being exacerbated because many coniferous trees in the region are sick or dying due to air pollution. Another factor is that in the past villages managed their own particular rivers for water supply, hydro-power etc., keeping them largely free of excess sediment and debris. Shifts in the social conditions and management practices have resulted in neglect of many of the upland catchments allowing excess debris to accumulate in the channel and on the adjacent slopes. In the past downed trees were also collected and utilised for fire wood, but this practice is also declining. The problem of excessive debris flows in Bavarian rivers during extreme events is therefore likely to increase in the future. In 1990 an extreme flood event (estimated to have a return period of about $1000 \mathrm{yrs}$.) in the Lainbach and Arzbach river catchments in the Bavarian Alps resulted in the transport of a large quantity of woody debris which became trapped at a number of bridges located in the long profile where the channel gradient changes from that of a steep mountain stream to a piedmont stream flowing across an alluvial floodplain. As a consequence, flow under these bridges was constricted, causing overbank flow and extensive flooding of residential areas and four bridges were themselves seriously damaged.

To prevent any repeat of this problem it was decided to install debris retention devices in the upper reaches of the Lainbach and Arzbach catchments to protect the conveyence capacity and structural integrity of bridges and reduce the potential for overbank flows in urban areas. A number of physical model tests were carried out at the Hydraulics Laboratory of the Technical University of Munich. It was established that the best method for retaining debris, while allowing the downstream movement of water and sediment, was to use circular posts set into the channel bed, with the post spacing matched to the minimum length of debris that it was desired to trap. A number of different post configurations were tested in a rectangular plexiglass flume to determine the best alignment for retaining the imposed debris load while still passing the design discharge with minimum 
backwater effect (figure 1.1). It was found that alignment 2 (a downstream pointing "V") was the configuration with the best debris retention capacity and which had the least backwater effect when the device was filled with debris. Configuration 1 was found to be unsatisfactory because debris tended to be pushed up and over the barrier, while the shorter barrier length than that of configuration 2 meant that the flow had less area to pass through the structure so that the backwater effects were greater. Configurations 3 and 4 created less backwater effect than 1 , but slightly more than configuration 2 .

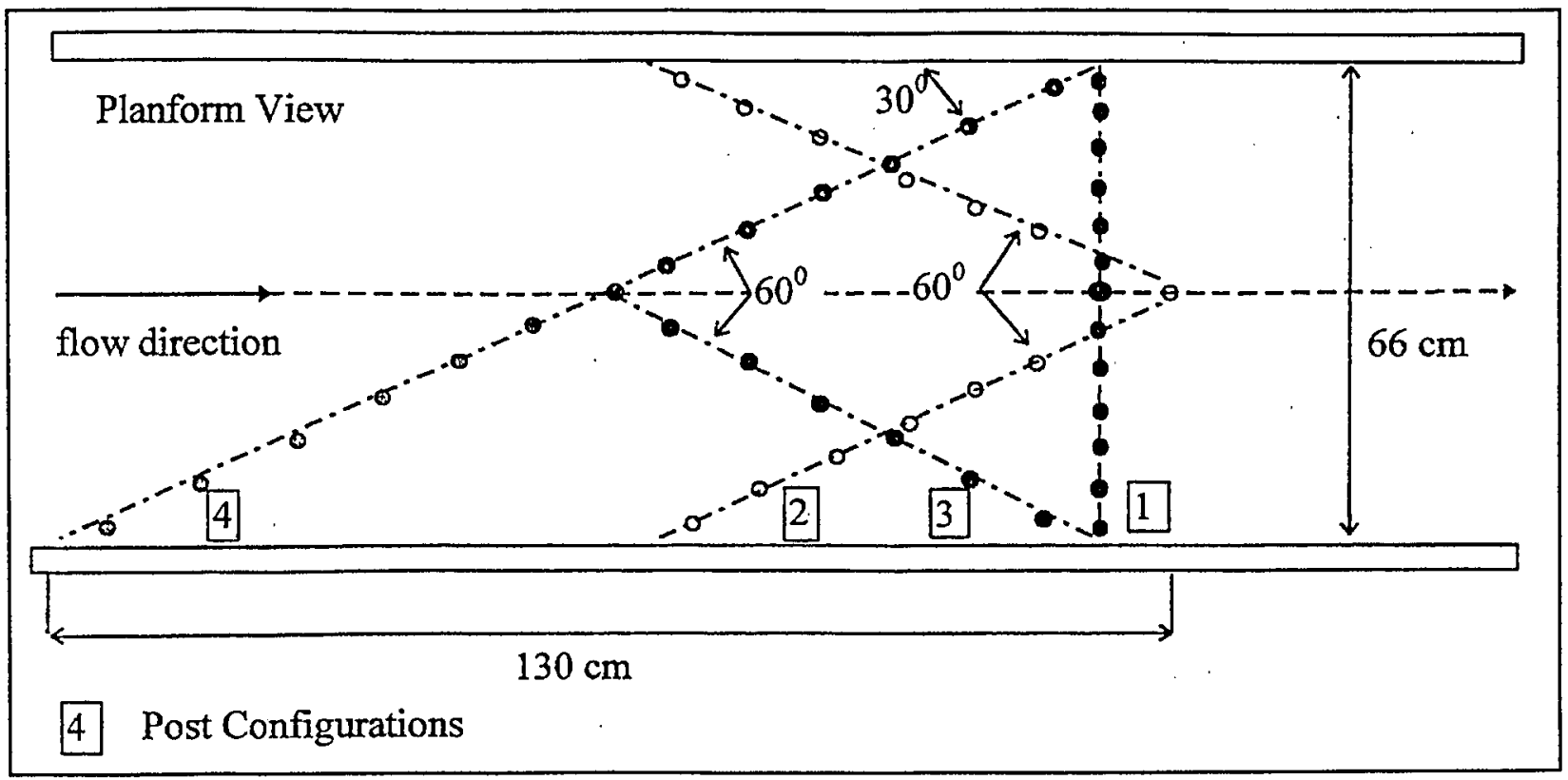

Figure 1.2 : Tested flume post alignments. Modified from Knauss (1985)

Scale models of the structures within their proposed prototype locations were then constructed, (figure 1.3). The debris retention structures have an upstream catchment area of $19 \mathrm{~km}^{2}$ in the Lainbach and $14 \mathrm{~km}^{2}$ in the Arzbach. The models were tested with a variety of scaled debris sizes, a range of discharges (design discharge $=125$ cumecs in Arzbach, and 200 cumecs in Lainbach), and a simulated sediment load. Both models were found to perform satisfactorily. Plates 1 and 2 show the scale models.

The Lainbach device was built first, with a double row of posts, but this was later found to be unnecessary and the Arzbach device, therefore, has only a single row. Post dimensions are $0.66 \mathrm{~m}$ diameter with a height of $4 \mathrm{~m}$ above the channel bed and each post consists of a steel sleeve with 


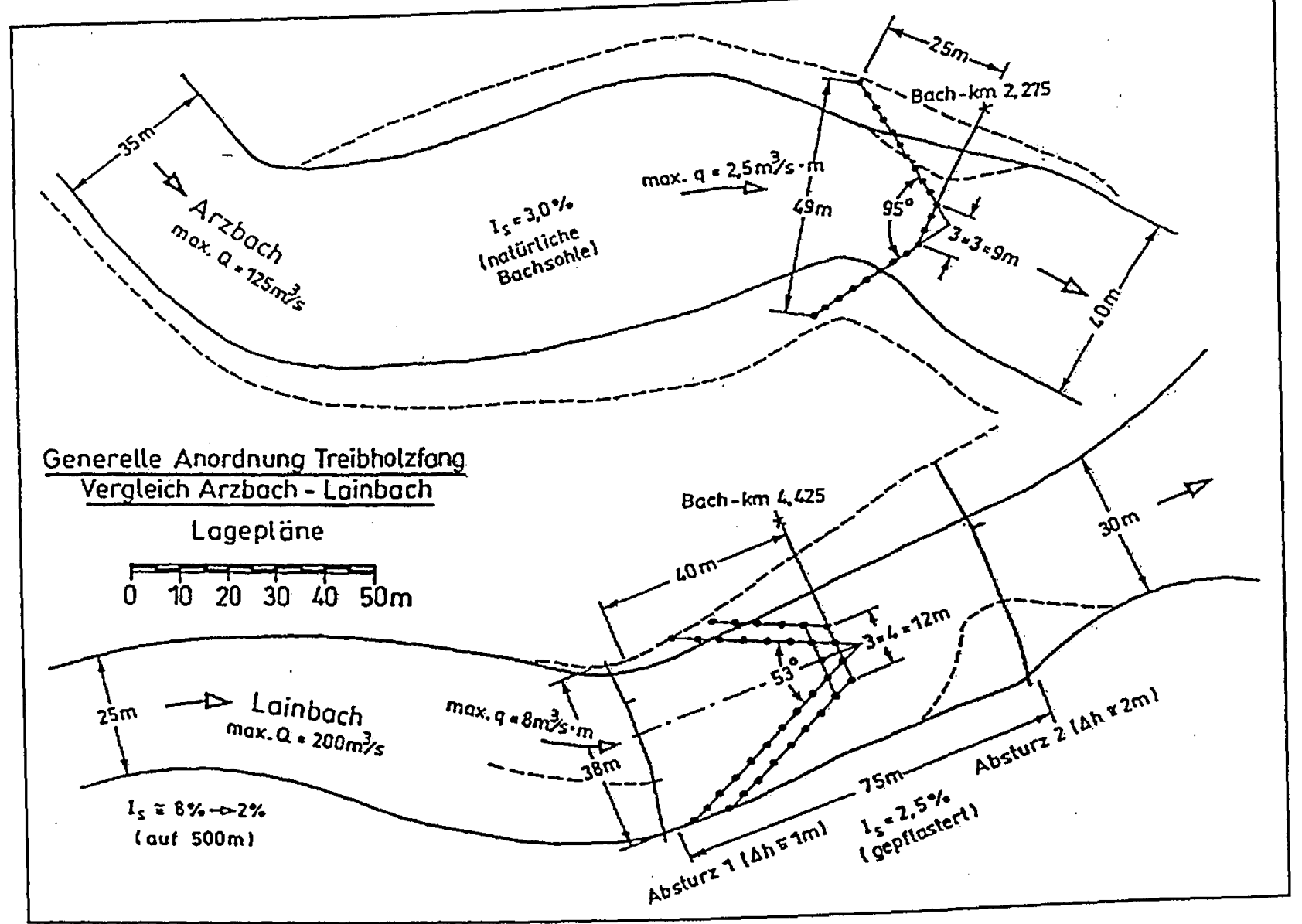

Figure 1.3 : Planform views of the model set-up for the Lainbach and Arzbach debris retention devices (after Knuass, 1985)

concrete core. Each post is set into a concrete foundation which is supported on pilings sunk $4.4 \mathrm{~m}$ into the channel bed. The posts are set into the centre of a basin built with massive, close fitting stone blocks on both the bed and banks to prevent scour. Figure 1.4 shows the constructional details of the posts and foundations.

The device on the Arzbach also has an energy dissipation pool downstream of the posts (see figure 1.5). Both structures must be cleaned periodically of debris and sediment although the Arzbach device has a central in-cut low flow channel designed to flush accumulated sediment downstream at low flow and so avoid starving the downstream areas of the sediment load necessary to supply transport and prevent channel degradation. 


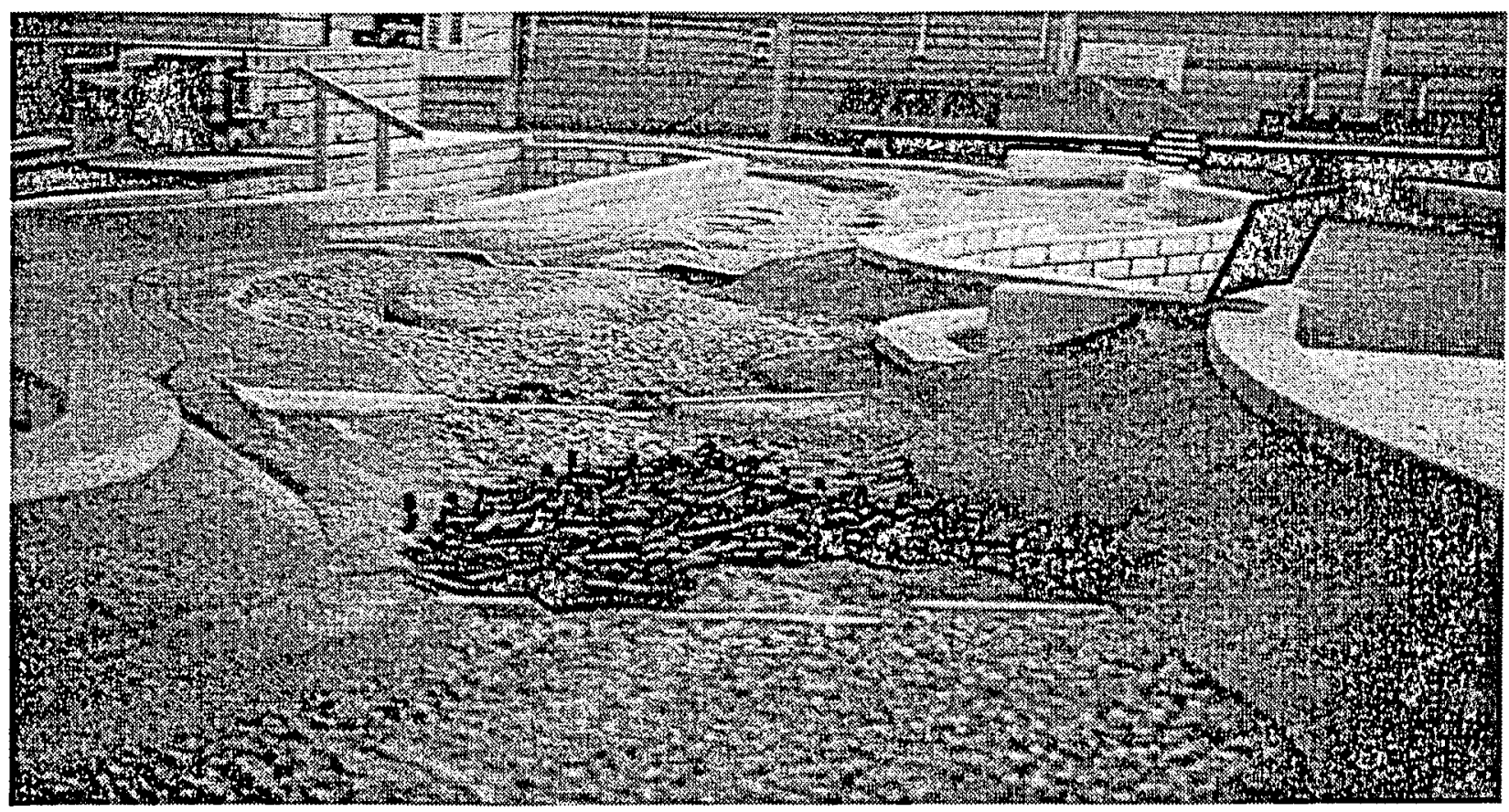

Plate 1 : Physical model of the Lainbach "Treibholzfang" with debris and sediment load. View downstream

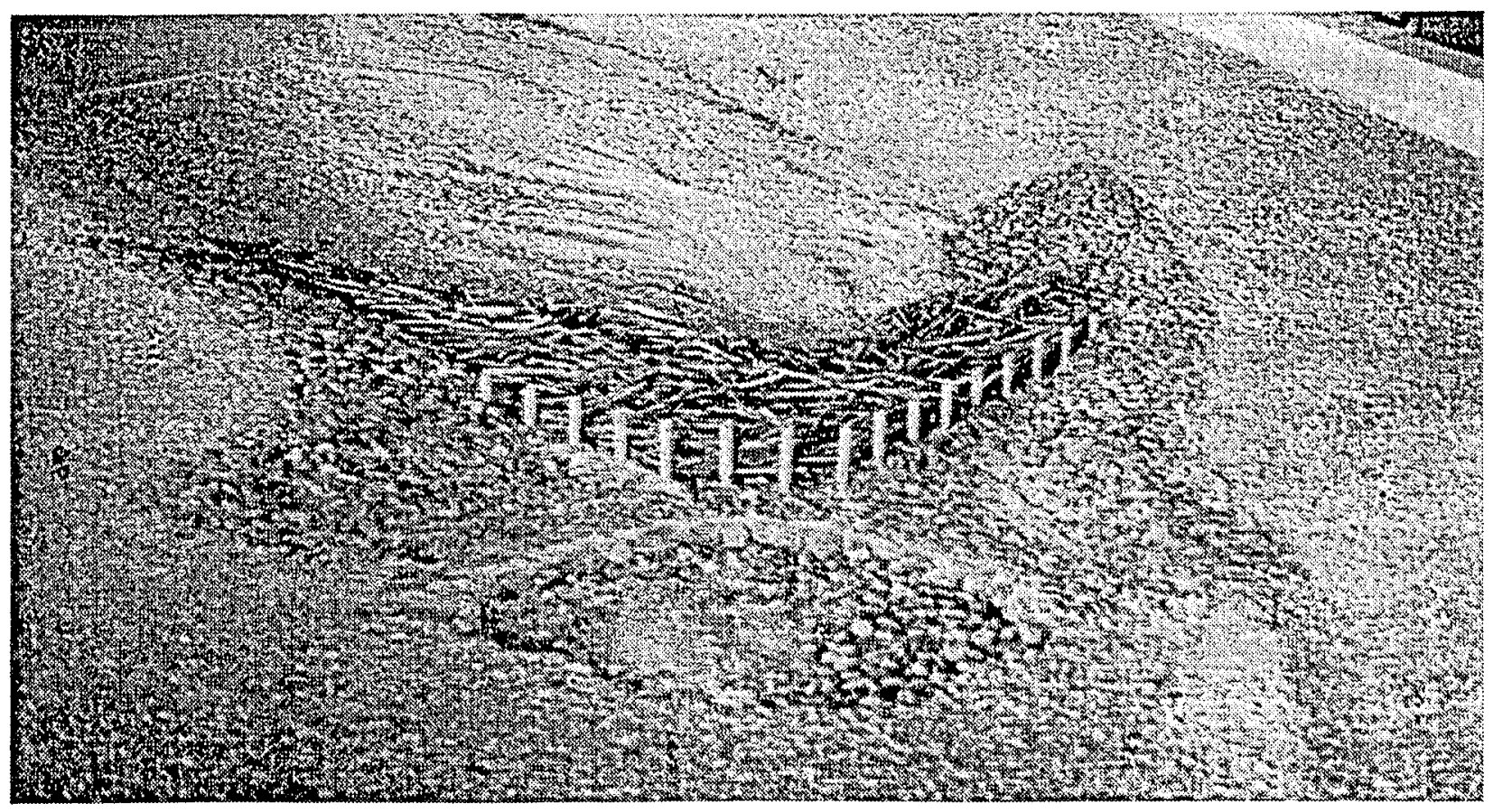

Plate 2 : Physical model of the Arzbach "Treibholzfang." Note the central low flow channel and stilling basin. View upstream 


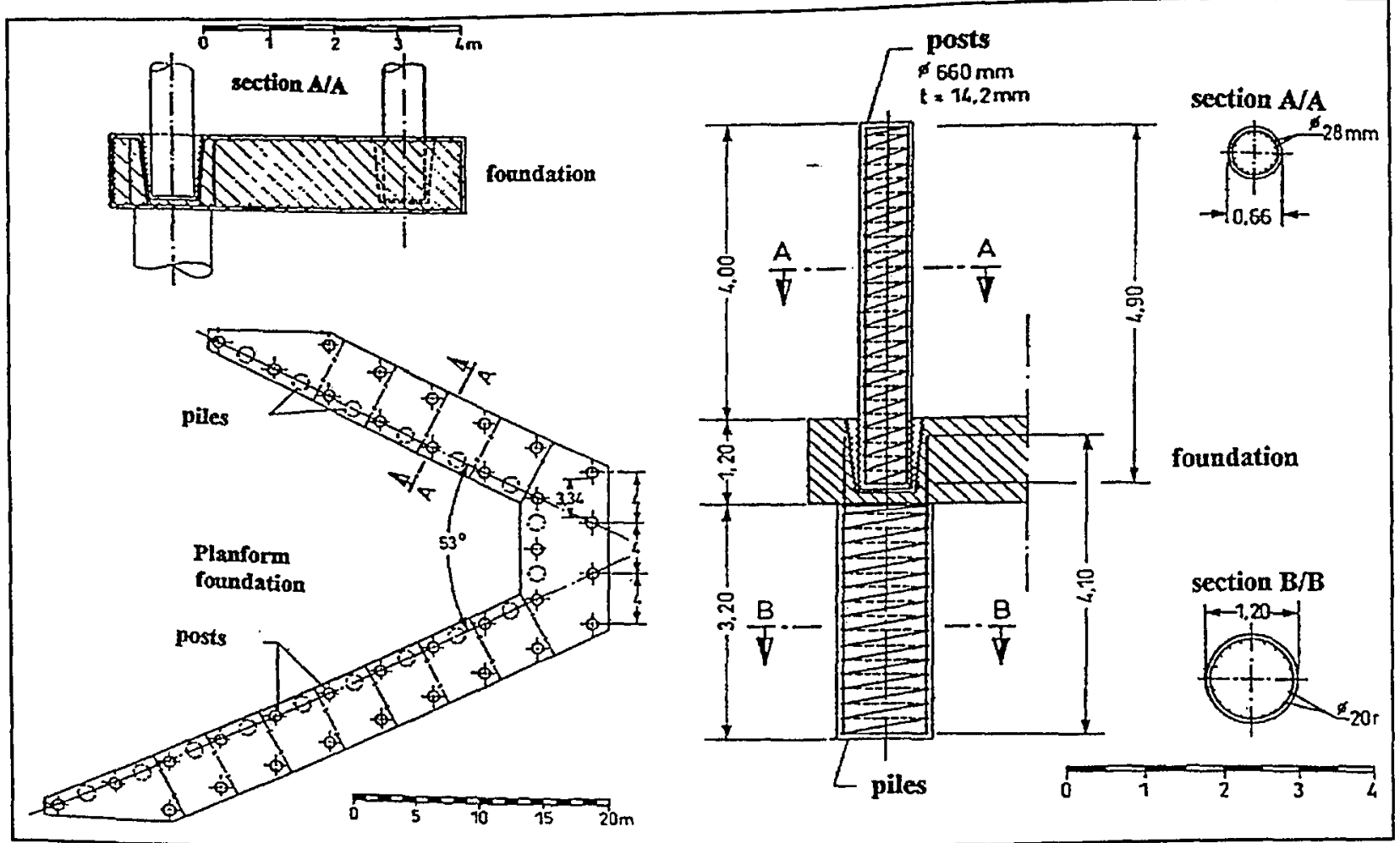

Figure 1.4 : Construction details of posts and foundations on Lainbach Treibholzfang (modified from Knauss, 1985)

The prototype structure on the Lainbach was completed in 1993 and was, at the time when visited (October 1995), being cleaned of a large sediment bar deposit which had accumulated upstream of the posts. The device on the Arzbach is currently under construction. The estimated cost of the device on the Lainbach, without maintenance costs, is DM 2 million ( $\$ 1.5$ million). Plates 3 and 4 show the prototype device on the Lainbach.

Configuration 2 has the best characteristics in trapping and retaining the most debris with the minimum backwater effect.

\subsection{Debris Retention Basins for Torrent Control}

Information in sections 1.3 and 1.4 were obtained from discussions with Dr A. Chervet at the ETH Institute of Hydraulics and Glaciology, Zurich, Switzerland.

Debris detention basins are small pools which have no continuous backwater and are designed to trap sediment and debris washed down by torrents from the steep flanks of the Alps. Their specific purpose is to protect roads and other structures in their path. The detention basins have small outlets 


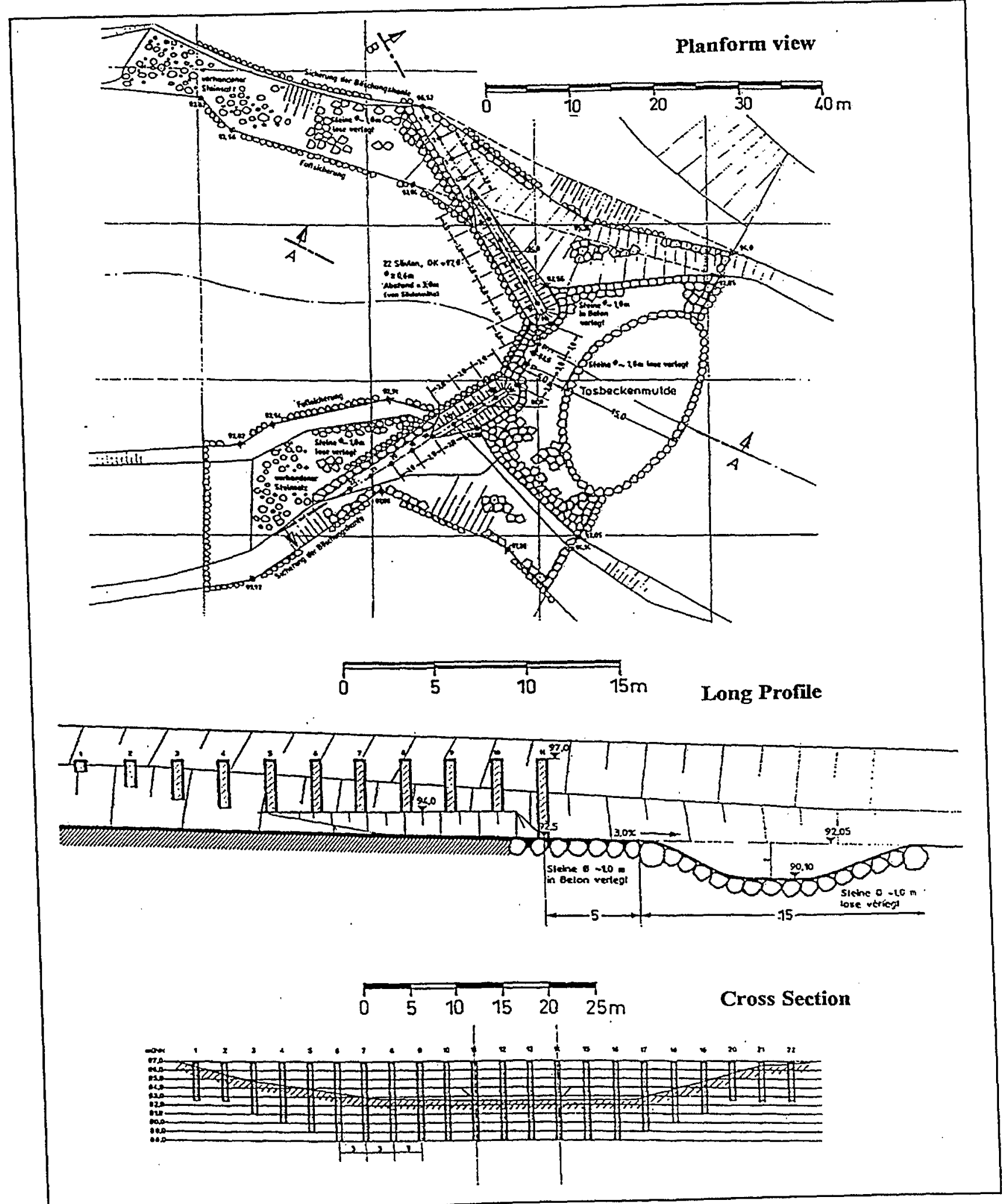

Figure 1.5 : Design plans for Arzbach Treibholzfang (modified from Knauss, 1985) 


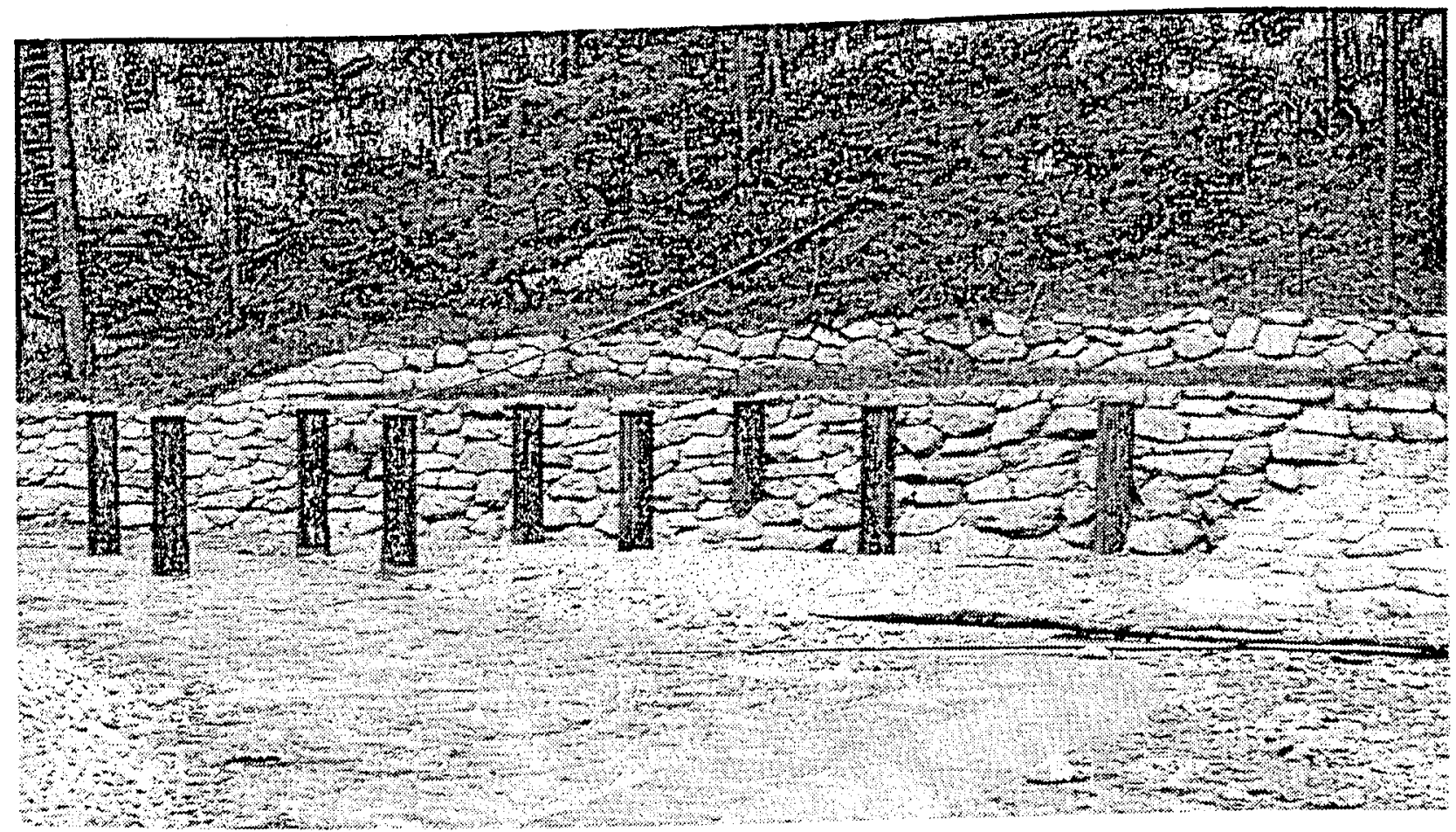

Plate 3 : Treiboholzfang device on the river Lainbach. View downstream

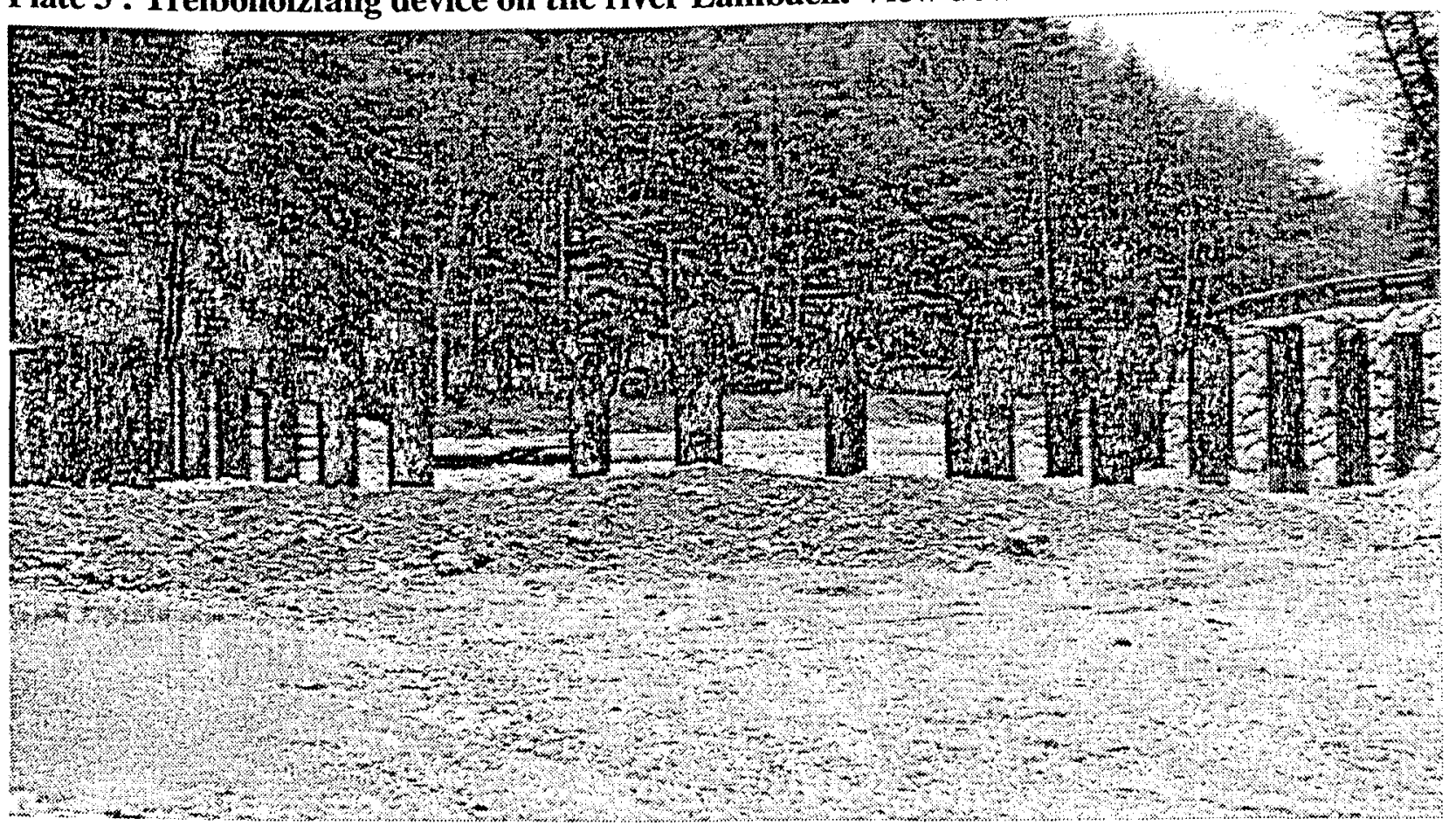

Plate 4 : Treibholzfang on the river Lainbach. Sediment removal operation. View upstream 
at the front, so that the accumulated sediment can be flushed out by degradation at low flows. A major problem, however, is that woody debris can block the outlet grill of the basin, so that sediment flushing does not occur, resulting in the structure being overtopped during flood events. The solution to this problem has been to construct slanting grilled weirs or box-type trash racks around the upstream side of the outlet grill, so that during storm events the flow can pass over the top of the trash rack and out through the grill plate. See Figure 1.6 below.

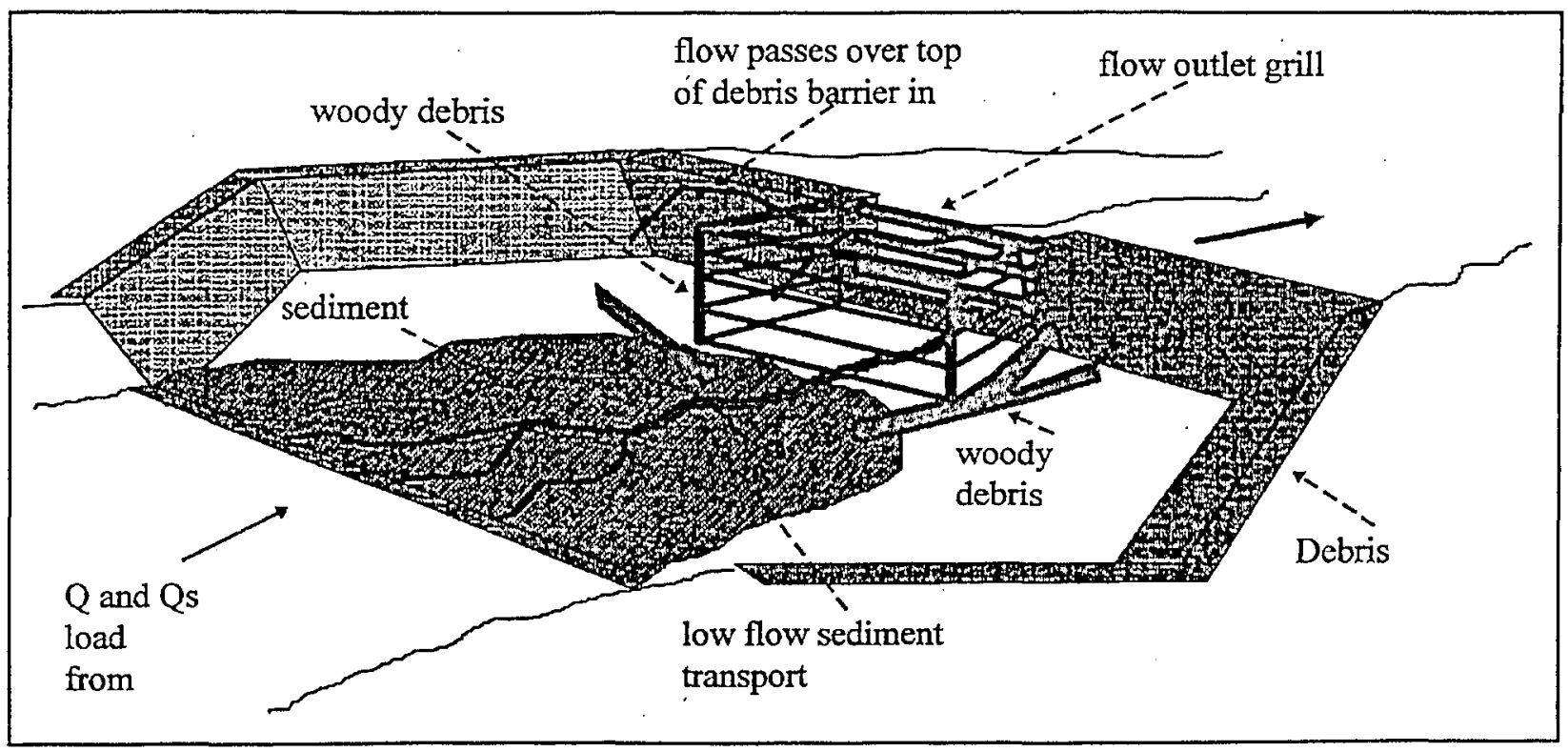

Figure 1.6 : Debris retention basin with woody debris protection device

\subsection{Diversion Tunnel : Campo Vallemaggia}

The Campo Vallemaggia is a tributary of the river Maggia, on the Swiss border with Italy. At the site in question there is a historical problem of erosion of the left bank in a bend, causing landsliding of the bank which is threatening a nearby village. The solution to this problem has been to build a diversion tunnel around the village through the flank of the mountain opposite. The upstream catchment area is forested and, as a consequence, floating debris could prove to be a problem at the tunnel entrance. The tunnel was designed to pass the total discharge and associated sediment load to prevent downstream channel degradation. Model tests were made in 1987-88 and construction began in 1994. 
The tunnel is $2 \mathrm{~km}$ long, has a bed slope of $2 \%$ in order to prevent abrasion (while the local channel slope is $10 \%$ ) and is designed to pass the 200 yr. flood (300 cumecs). See figure 1.7.

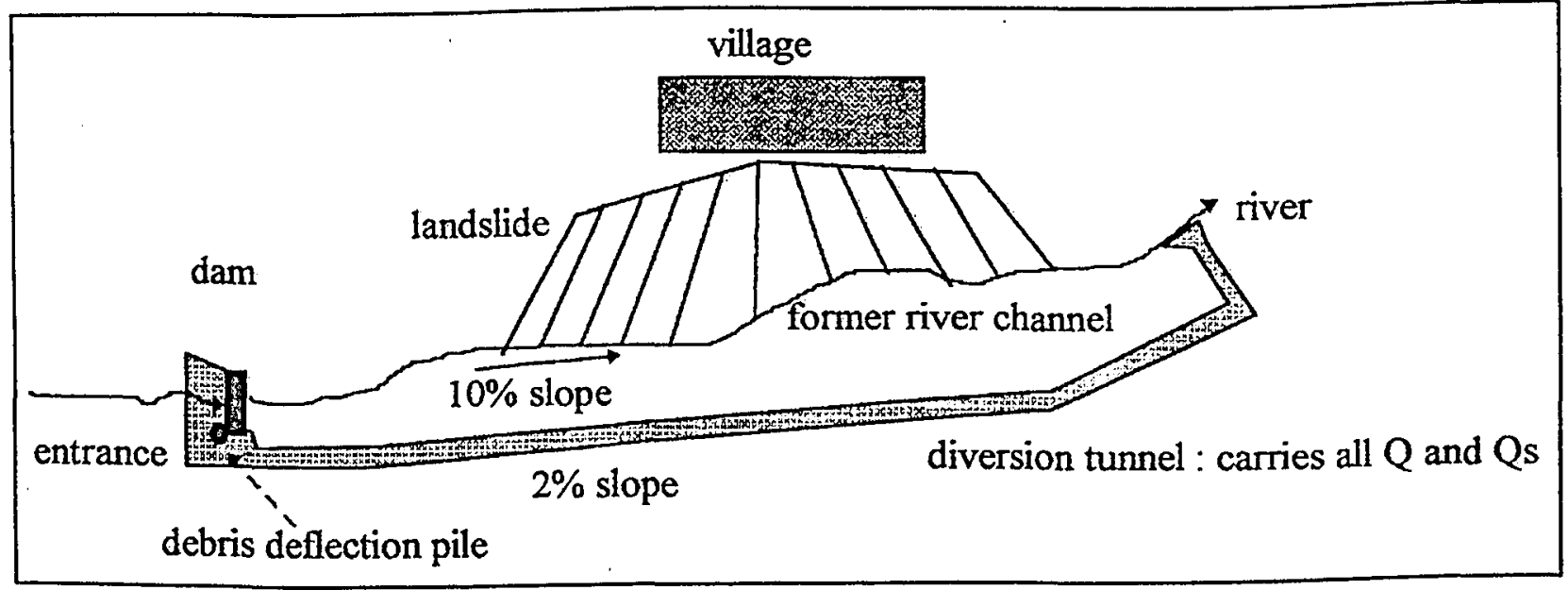

Figure 1.7 : Schematic diagram of the Campo Vallemaggia diversion tunnel

The solution tested to prevent the tunnel from clogging with woody debris was the construction of a $2.4 \mathrm{~m}$ diameter steel and concrete pile upstream of the tunnel entrance to rotate debris parallel to the flow direction into the tunnel. Model test runs were carried out with and without debris and landsliding events upstream were simulated. The results showed that more debris was rotated parallel with the flow when the pile was present than when it was absent. Smaller debris was found not to accumulate in the tunnel. One problem encountered in the tests was that of scaling between the model and the prototype, as the simulated debris has far less elasticity than that found at the prototype. The pile was initially designed with a sloping, pointed upstream side, but this was found to offer a negligible improvement in efficiency as compared with a simple, cheaper cylindrical pile.

\subsection{Debris Problems at Spillways : The Palagnedra Dam}

The following information is taken from two articles, Bruschin et al., 1982 ("The overtopping of the Palagnedra dam") and Vischer and Trucco 1985 ("The remodelling of the spillway of Palagnedra") and from a conversation with Dr A. Chervet at the ETH Institute of Hydraulics and Glaciology, Zurich, Switzerland. 
The Palagnedra dam lies in the catchment of the Melezza river, in the southern Swiss canton of Ticino. It has a design storage capacity of $4.8 \times 10^{6} \mathrm{~m}^{3}$ and is fed from a catchment area of $140 \mathrm{~km}^{2}$, over $50 \%$ of which is forested and lies on steep slopes. The structure consists of an arched gravity dam, $120 \mathrm{~m}$ long and $72 \mathrm{~m}$ high and a $45 \mathrm{~m}$ high diaphragm wall built within glacial moraine material in a secondary valley. The flood spillway had an uncontrolled ogee crest on top of the dam and a steep chute terminated by a ski jump. The crest was divided into 13 openings, the boundary walls of which functioned as piers for an overpassing road. The nominal discharge capacity of this spillway was $450 \mathrm{~m}^{3} / \mathrm{s}$. (Plate 5).

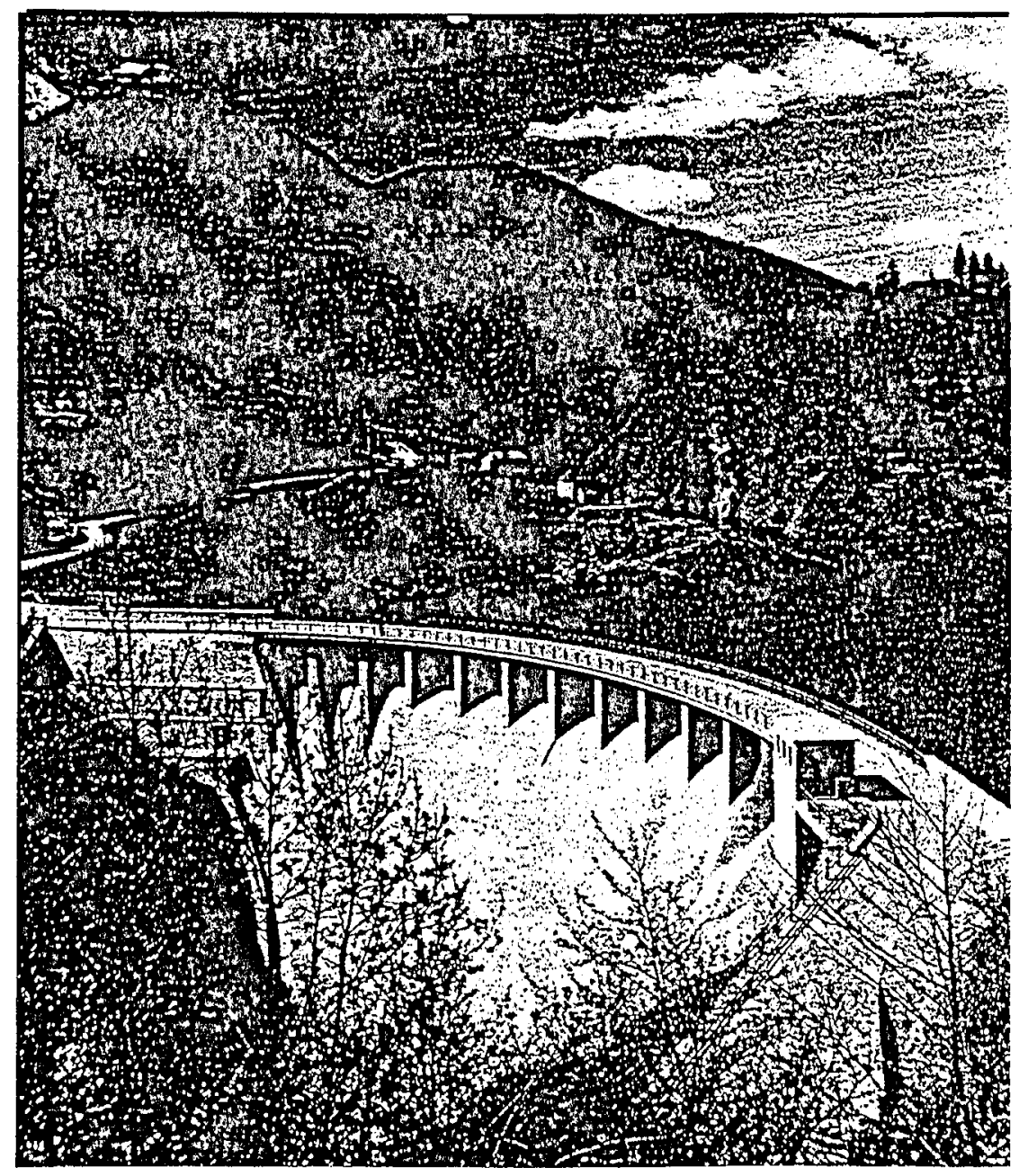

Plate 5 : Palagnedra dam prior to remodeling of spillway (after Vischer \& Trucco, 1985) 
On 7th August, 1978 an extreme storm event occurred in the region causing a flood wave, carrying a huge quantity of logs and wooden debris, to pass down the Melezza river to the dam. The volume of debris was later estimated to include about $25000 \mathrm{~m}^{3}$ of wood). About $1.8 \times 10^{6} \mathrm{~m}^{3}$ of sand and gravel were also deposited in the reservoir. Debris build-up at the spillway partially obstructed the openings and caused the dam to overtop over its entire length. The peak discharge at the spillway was estimated to be just under $2000 \mathrm{~m}^{3} / \mathrm{s}$. Plate 6 shows the dam choked with wooden debris after the flood event on the 8th August 1978. The main dam suffered insignificant structural damage, but about $50000 \mathrm{~m}^{3}$ of glacial moraine material was eroded from the downstream side of the diaphragm wall, which seriously endangered its stability.

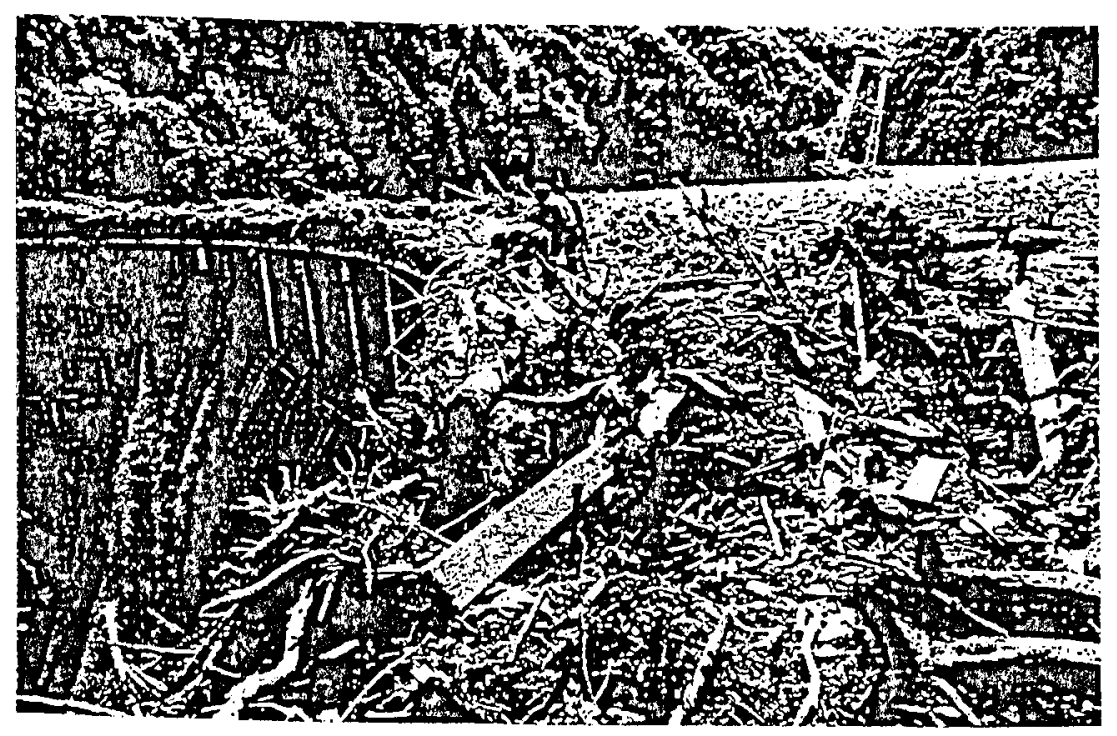

Plate 6 : Dam choked with debris on the morning of August
8th, 1978 (after Vischer \& Trucco, 1985)

In the aftermath of the event a study was carried out to try and piece together the sequence of events that took place and to understand the meteorological and hydrological conditions that generated the flood wave and associated debris build-up. The dam spillway was remodelled and the design tested with new discharge levels and a simulated debris load at the Laboratory of Hydraulics, Hydrology and Glaciology, at the Federal Institute of Technology in Zurich. The remodelled spillway had to satisfy a new design discharge of $2,200 \mathrm{~m}^{3} / \mathrm{s}$, the avoidance of woody debris build-up at the weir crest and satisfactory flow conditions at the weir crest, ski-jump and in the canyon downstream. 
Measures tested in the physical model and later implemented were:

- Raising the abutments by $4 \mathrm{~m}$ to prevent overtopping.

- Removal of the dam top bridge and supporting piers to_create a continuous weir crest.

- Raising and remodelling of the spillway guidewalls to ensure undisturbed passage of the increased discharge and debris load. Plate 7 shows the scale model with new spillway design.

The paper by Bruschin et al. (1982) concludes that a number of important factors must be considered in the design of spillway likely to receive significant amounts of debris including: analysis of the hydrological and meteorological environment; consideration of potential extreme events; examination of high yield sediment and debris sources within the catchment and consideration of the stability of slopes in upstream afforested areas. Dr. Chervet also suggested that any spillway pier should be set at least $12 \mathrm{~m}$ apart to avoid the potential for build-up of woody debris (original pier spacing at the Palgnedra dam was $5 \mathrm{~m}$ ).

\subsection{Spillway Design with Debris Retention Devices}

Knauss (1985) describes a model that was constructed at the Hydraulic Laboratory of the Technical University of Munich in Obernach, Germany to test a new spillway tunnel on the Sylvenstein Dam. This design incorporates debris retention posts at the inlet consisting of five columns, $11 \mathrm{~m}$ high with a free space of $4 \mathrm{~m}$ between them (Plate 9). The spillway tunnel itself is $6 \mathrm{~m}$ in diameter and has free surface flow so that smaller debris that passes through the posts can be transported down the tunnel. This structure does not have a crane or mechanical trash rack to remove the debris. Figure 1.8 shows the structural details of the spillway.

Knuass (1995, in conversation) has suggested that woody debris build-up in reservoirs is a problem in Bavaria where dams are often at low elevations so that debris is fed into them from upstream, whereas in Austria debris is not such a problem in reservoirs because many dams are located above the tree line. Hence, the location of reservoirs in relation to the watershed tree-line should be used to asses the likely severity of debris-related problems in feasibility level studies.

\subsection{Bremgarten-Zufikon Powerplant (Switzerland)}

Bisaz et al. (1976) examine a phenomenon at deep-seated turbine intakes of run-of-river powerplants utilising bulb turbines where a separation layer on the upstream side of the turbine gives rise to a zone of horizontal anti-clockwise rotating water. On the surface within this area a 


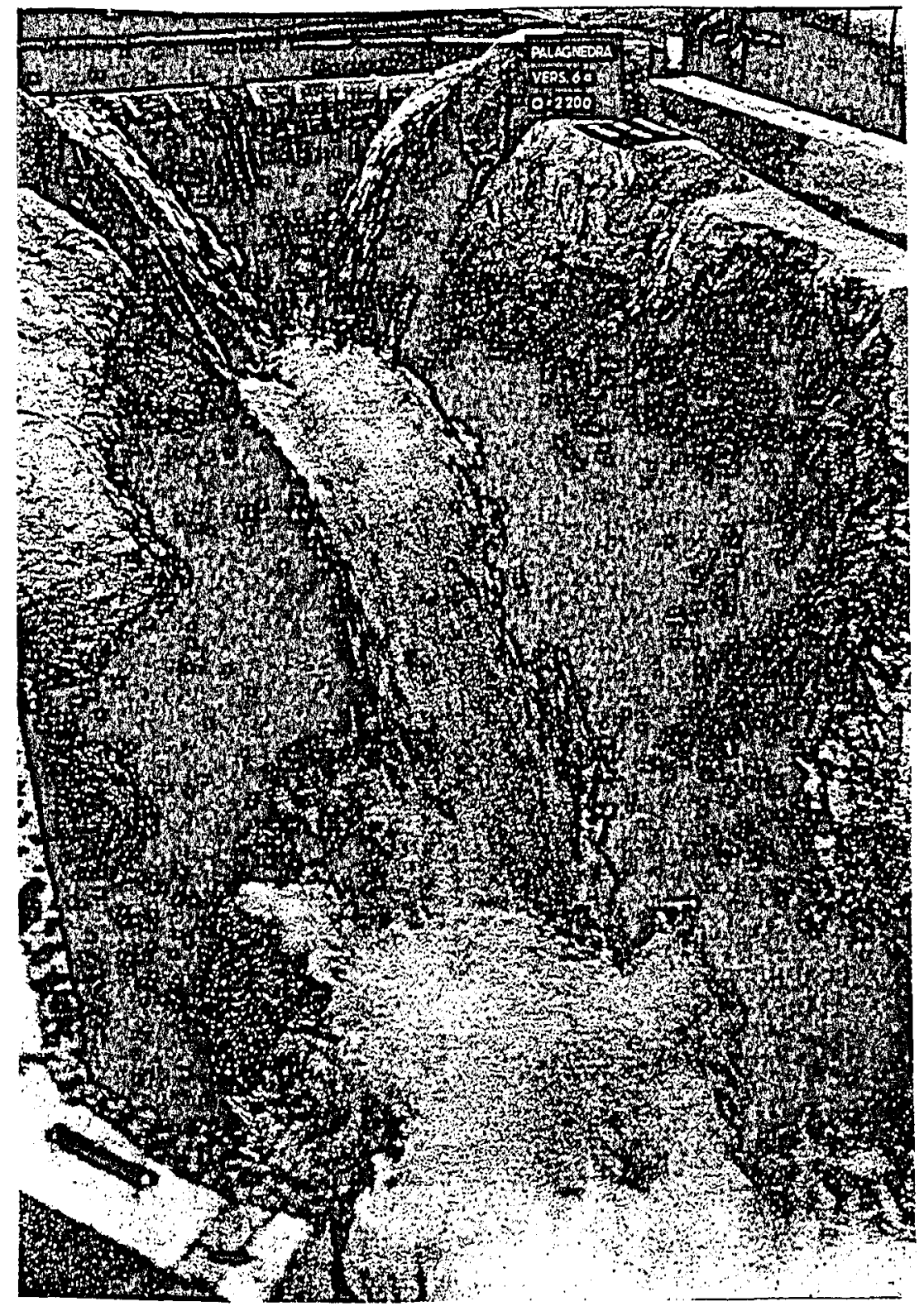

Plate 7 : Physical model (scaled 1:50) with remodelled spillway. Discharge $2.200 \mathrm{~m}^{3} / \mathrm{s}$ (after Vischer \& Trucco, 1985)

movement of water in the upstream direction occurs, so that arriving floating debris is retained some metres from the trash racks or front of the upstream face, out of the range of the mechanical rake (figure 1.9). A vertical, radial current may also arise in this zone and this can develop into a vortex 


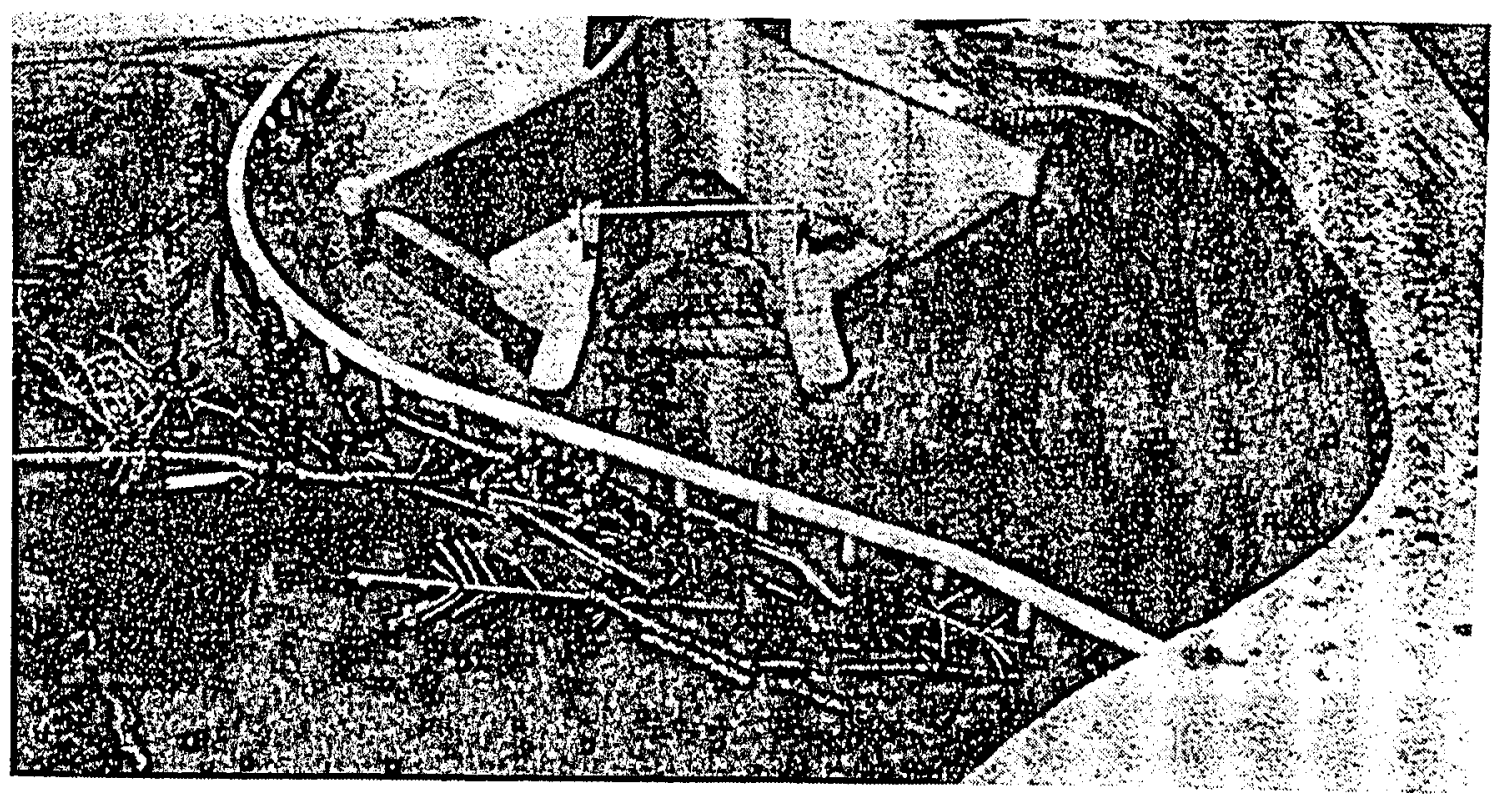

Plate 8 : Fixed pillar-interceptor with service bridge (after Hartung \& Knauss, 1976)

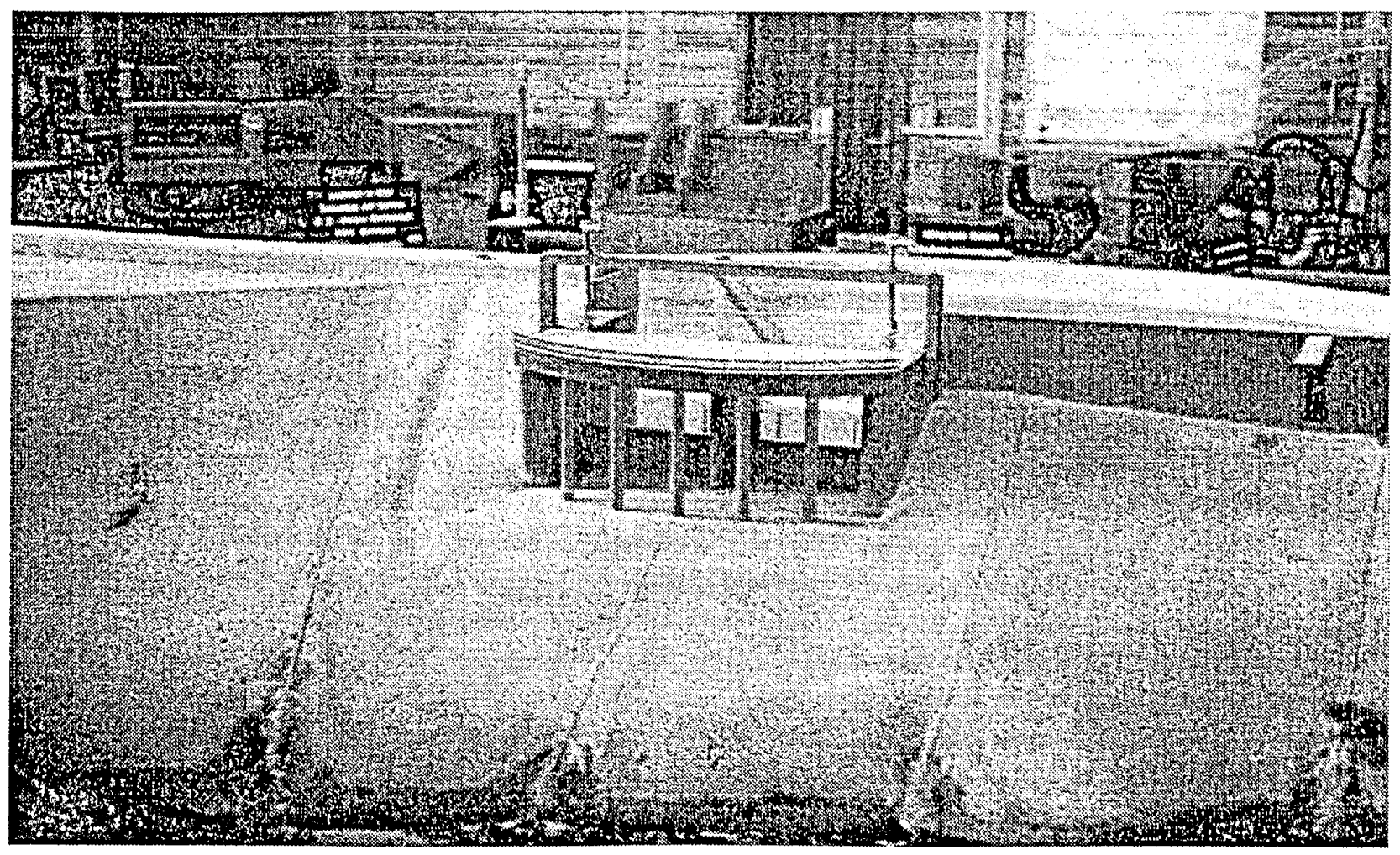

Plate 9 : Model of new Sylvenstein Dam spillway with debris retention device 

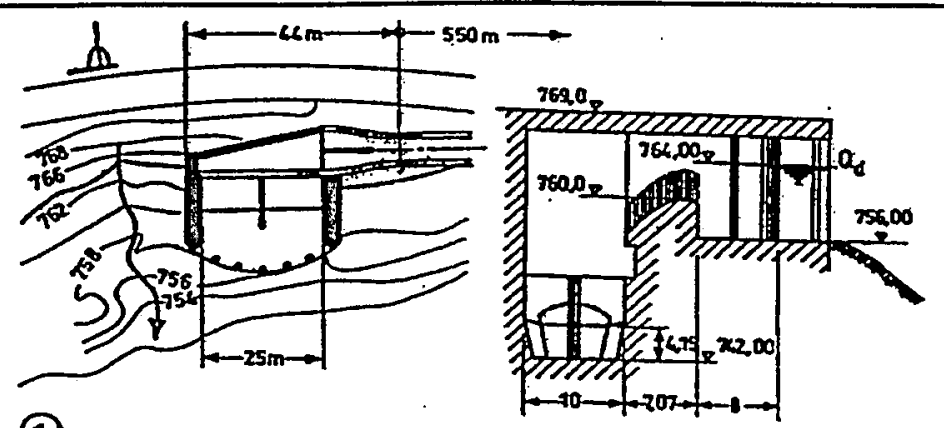

(1)

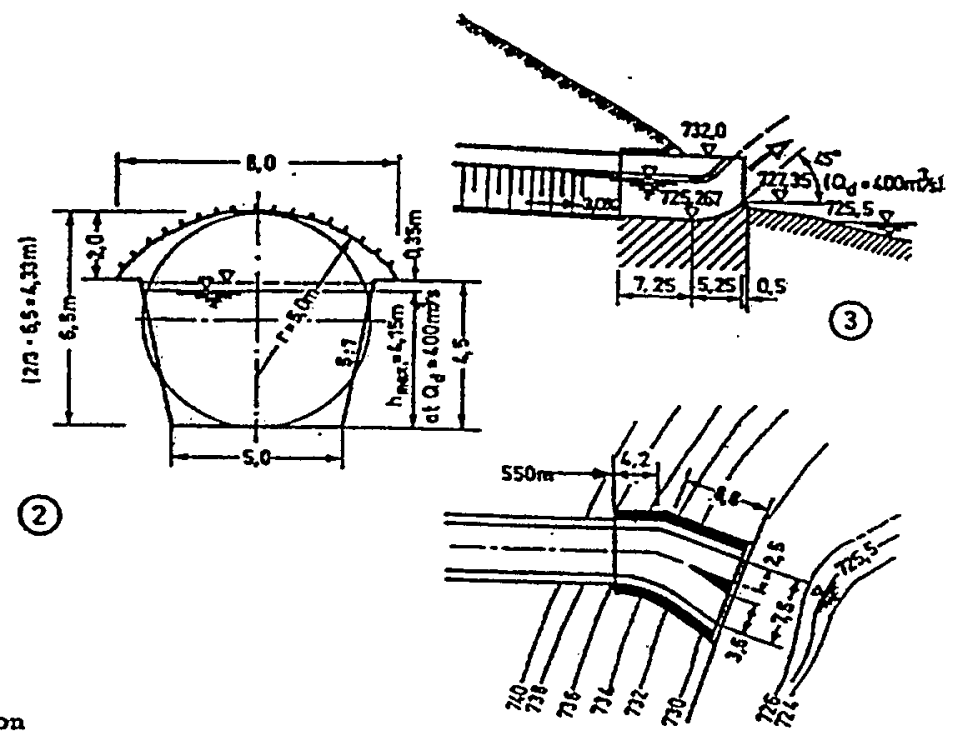

Figure 1.8 : Structural details of the spillway for the Sylvenstein Dam (from Knauss, 1985)

that may suck air and debris from the surface into the intake. This can consequently impair the smooth running of the turbine.

A number of tests were carried out on a scale model of a run-of-river plant on the Reuss near Bremgarten-Zufikon, Switzerland to test a device called an injector shaft which was designed to eliminate these vortex phenomena. The injector consists of a shaft installed in the upstream face of the intake dam and a scum board (see figure 1.10). This shaft creates a suction effect because the increasing proportion of the velocity head to the total head inside the shaft induces a current near the water surface towards the front of the upstream face. Floating debris is, therefore, carried to the face of the trashrack, where it can be removed with a raking device. The model tests proved that the injector was successful in this respect and also helped to prevent the vertical vortex from forming 


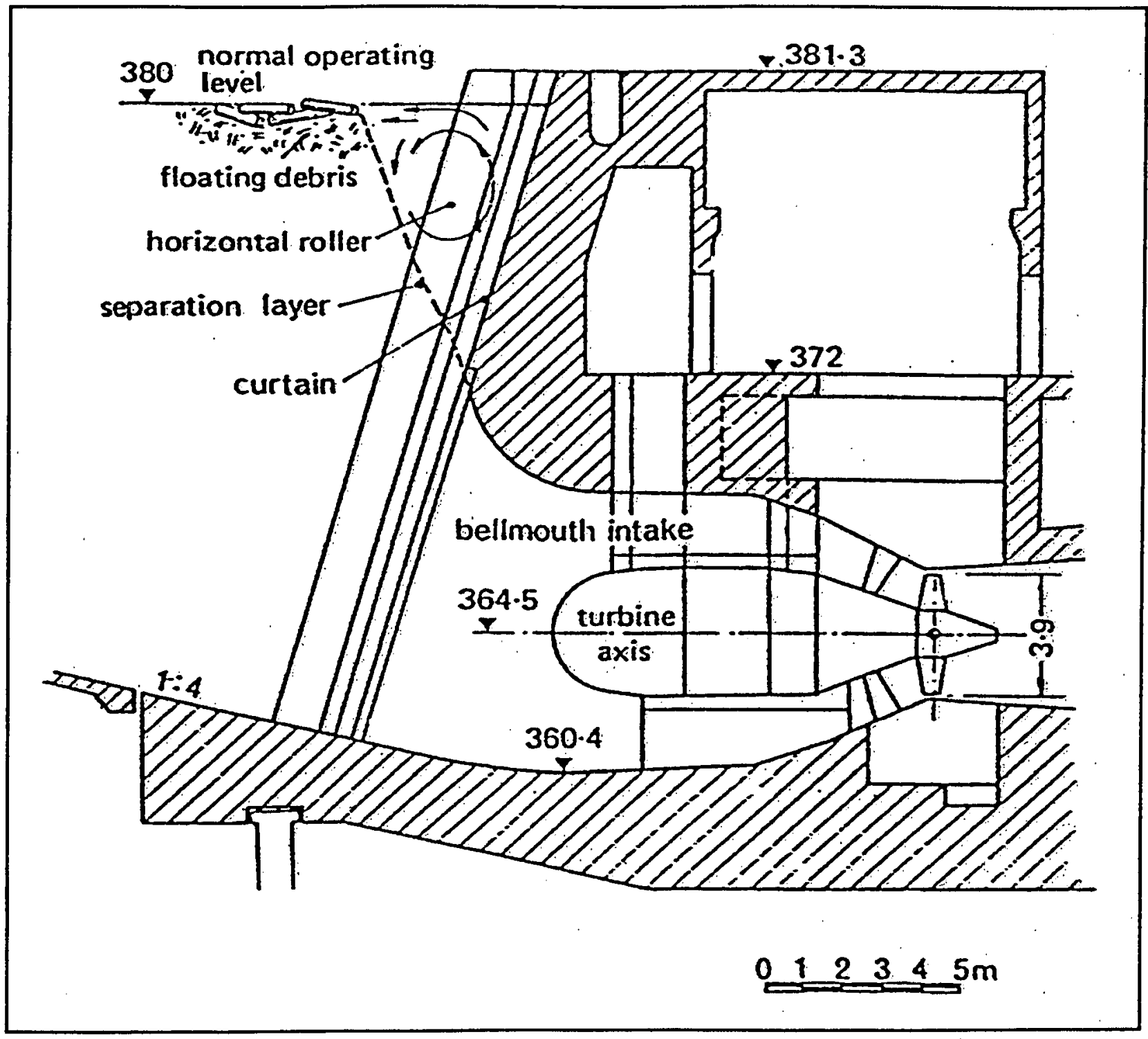

Figure 1.9 : Run-of-river turbine with separation layer and currentless zone (longitudinal section). Modified from Bisaz et. al. (1976)

by disturbing the turbulent separation layer between the ponded surface water and underlying current zone. 


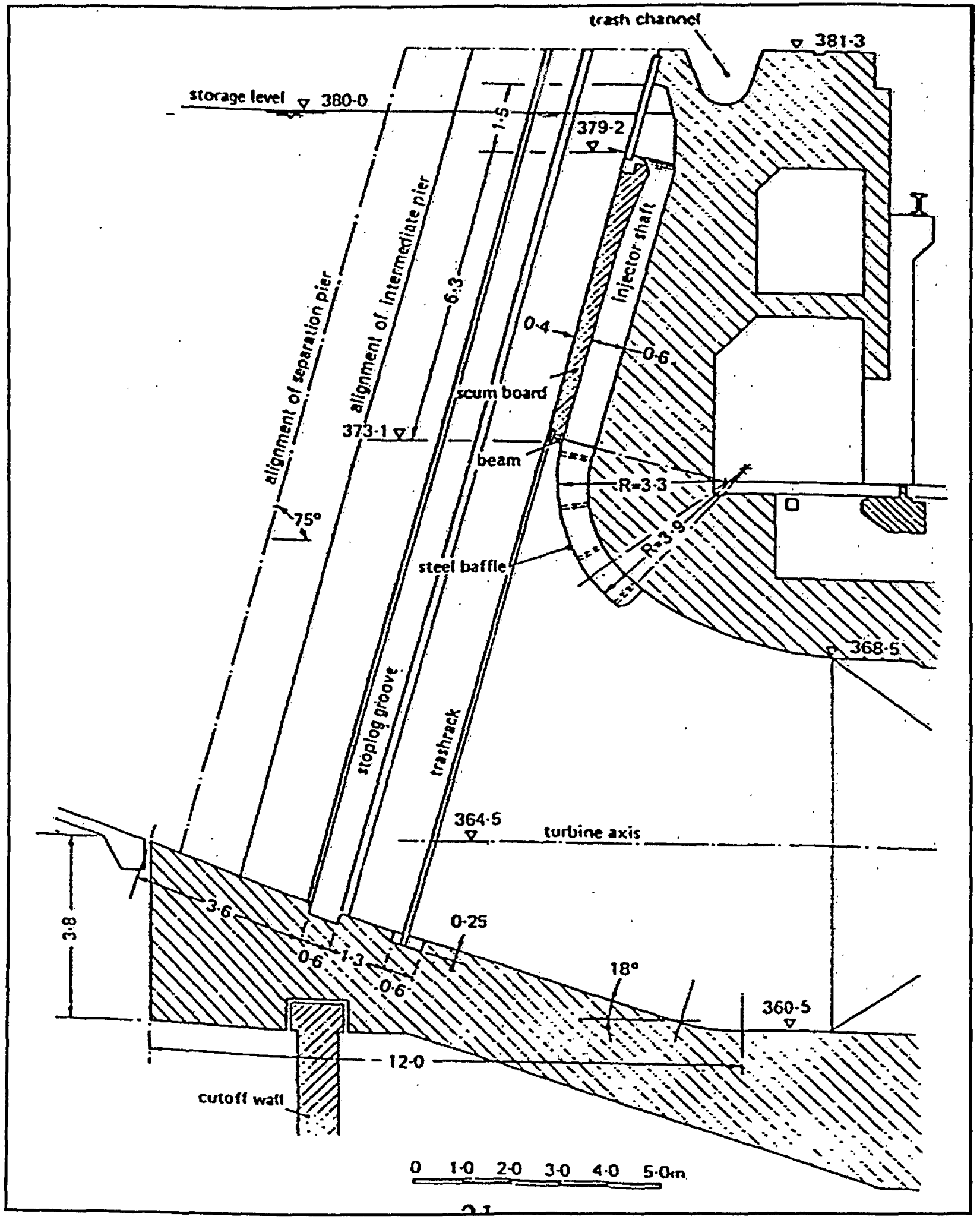

Figure 1.10 : Position of Injector shaft at turbine intake. Modified from Bisaz et al. (1976) 


\section{DEBRIS CONTROL AT HYDRAULIC STRUCTURES IN SELECTED AREAS OF THE UNITED STATES}

\subsection{Location Map}

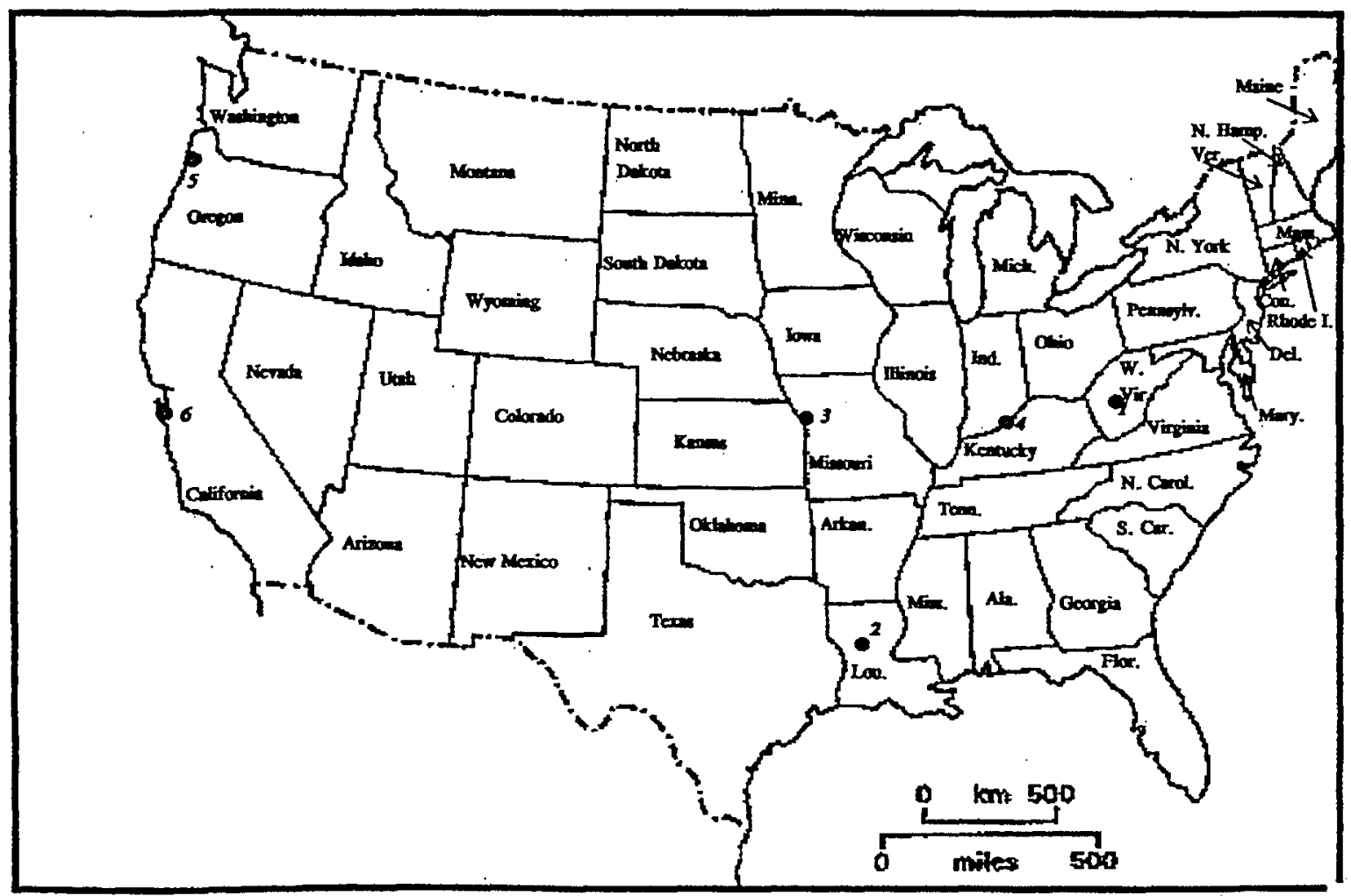

1 : Huntington District, Huntington, WV

2 : Vicksburg District, Monroe, LA

3 : St. Louis District, St. Louis, MO

4 : Louisville District, Louisville, KY

5 : Portland District, OR

6: San Francisco District, CA 


\subsection{Huntington District}

On 4-5 September, 1995, the third author travelled to Huntington, West Virginia, to meet with

Mr. Jon Fripp and Mr. Sutten Epps of the Huntington District, U. S. Army Corps of Engineers. The focus of the meetings was to discuss the debris and drift problems they currently experience at the Bluestone Dam. Bluestone Dam is an instream structure on the New River located approximately $64 \mathrm{~km}$ southeast of Charleston, West Virginia. The dam is the second structure in a series on the river; with Claytor Lake Dam located immediately upstream. The reservoir provides flood control and recreation benefits to the region.

The Bluestone Dam is a concrete structure that completely spans the width of the New River Valley thereby intercepting all tributary flow. Flow is passed through the dam via a series of intake wells and tunnels that span the upstream dam face. Emergency spillways, regulated by tainter gates, span the top of the dam crest. The dam was constructed in 1947.

The upper New River basin is characterized by a mountainous, wooded terrain that is subjected to intense rainfall-runoff events. The combination of Claytor Lake Dam releases with tributary runoff results in flood water hydrographs that can rise from pool level to flood stage in an extremely short period of time (12-48 hours). Vast quantities of debris and drift routinely accompany the rising limb of the flood hydrograph. The debris and drift are usually allowed to accumulate until a sufficient mass debris develops that can be efficiently flushed through the dam. Approximately 3.25 to 8.1 hectares of debris and drift accumulate at least once annually. It is not unusual that 8,000 to 15,000 tonnes of debris may collect in a single event. A summary of events and estimated drift accumulations (acres) are presented in Appendix B for the period 1982 through early 1995.

On September 5, 1995, the third author was escorted to Bluestone Dam to observe the site and meet with Mr. David Eskridge, Dam Operations Supervisor. Mr. Eskridge indicated that debris passage and cleanup were addressed by several means.

- All plastic and domestic/industrial debris were routinely collected using a motorized barge. Only woody debris and drift were passed through the dam intake.

- Debris and drift that accumulate along the shoreline adjacent to the dam were periodically collected by a government contractor. 
- Small debris and drift accumulations ( $<$ half a hectare) may occasionally be collected using a grapple or barge-mounted clamshell.

- The most common means of passing the debris and drift through the dam is by a co-ordinated flushing operation linked to the peak and recession limb of a flood hydrograph. Debris is usually allowed to accumulate until a major storm event occurs. The maintenance staff is alerted when Claytor Lake Dam is about to release flood water. When the flood crest approaches Bluestone Dam, one of the intake towers is opened and all flow is released through the single intake. The inflowing debris is allowed to accumulate against the face of the dam. The motorized barge with the clamshell is used to manage and guide the debris toward the intake. Large debris accumulations ( 4 hectares or more) require 3 to 21 days to route the debris mass through the dam.

The larger debris accumulations span the whole width of the river valley and wedge against the dam face. A photograph of the March, 1993 flood event is presented in Appendix C. Approximately 16 hectares of drift and debris are observed prior to passage. In addition, a photograph illustrating the January, 1995 event demonstrates how the debris compacts against the dam face. Approximately 14 hectares of debris accumulated during the January flood.

The debris passage is co-ordinated with the flood hydrograph to provide sufficient flow to carry the debris downstream. Approximately thirteen kilometers downstream of Bluestone Dam are the Bluestone Falls, a state preserve area. Debris often collects on or near the Falls, which, in turn, angers local citizens and environmental groups mainly because the debris affects the areas aesthetic qualities. Public relations and environmental concerns have guided debris passage operations. The Huntington District is developing and designing a debris bypass modification to the Bluestone Dam. A series of debris intakes may be placed near the centre of the dam (larger than the intakes currently used). A new barge (with a crane) and rake are proposed for managing debris and guiding it to the intakes. Debris passage will continue to be co-ordinated with the flood hydrographs. This proposed new project is discussed in more detail in section 2.6

\subsection{Vicksburg District}

On October 16-17, 1995, third author travelled to the Monroe Area Office of the Vicksburg District and met with Mr. Corkey Corkern, Area Supervisor. The debris and drift related problems are 
directed to lock and dam operations throughout his area of responsibility. Mr. Corkern escorted the third author to the Columbia Lock and Dam where he was afforded a tour of the facility. In addition, he was able to interview Mr. Ray Shumaker, Lockmaster of the Columbia Lock and Dam, Mr. Doug Prudnomme, Lockmaster of the Jonesville Lock and Dam, and Mr. Fred Pittman, Lockmaster of the J. H. Overton Lock and Dam.

A Lock and Dam is a structure designed to maintain sufficient in-channel flow depths that allow a river channel to be navigable. The dam spans the full width of the river and creates a backwater pool that permits navigation. To permit the passage of flood waters, regulated and unregulated weir crests control minimum stage levels. Tainter gates are often placed atop the dam crest, which allows the operator to manage appropriate stage-discharge levels during high water stages. The lock is usually situated adjacent to an abutment of the dam and the river bank. The lock is a hydraulically operated channel that extends through the dam. The lock entrance and exits are controlled by miter gates. A system of pumps is used to manage the water surface in the lock to align it with either upstream and downstream water surface elevations. The lock permits the passage of vessels through the dam.

Common problems related to debris and drift in lock and dam operations include:

- Debris accumulation in the lock approach, often debris is trapped against the miter gates.

- Conveying the debris through the lock. Debris often wedges into hydraulic systems, pipes, and cables in the gate and lock areas.

- Debris gets caught in the outlet works of the lock after being conveyed through the lock.

- Debris accumulates adjacent to the dam and tainter gates.

- Debris often accumulates in the tainter gate during the flushing operations. In addition, debris may damage the tainter gates (i.e., removing paint, protective covers, etc.) during flushing. Extensive corrosion often results from the damage.

- The lock and dam is occasionally overtopped. Debris accumulates in the overbank areas and must be collected.

Because of the unique design and operational aspects of each lock and dam, each lockmaster has developed a customized approach to debris management. A brief summary of operations at each of the three lock and dam structures follows. 


\subsubsection{Columbia Lock and Dam}

Mr. Ray Shumaker, Lockmaster, provided a tour of the Columbia Lock and Dam located on the Ouachita River, 30 miles south of Monroe, Louisiana. The structure consists of a dam with an unregulated weir and spillway with four tainter gates ( 7.9 meters high). The dam abuts to the lock that is 366 meters in length and 25.5 meters wide. Miter gates control the lock entrance and exit. Debris and drift are routinely conveyed along the river. Prevailing flow patterns and winds direct the majority of the debris toward the lock structure and operations concentrate on problems in this area. Debris accumulations are quite frequent during passage of flood hydrographs. When debris and drift accumulate in sufficient quantity that it impacts vessel passage, a "mule" barge is used to guide the debris to the miter gate entrance. Air bubblers have been installed at the miter gate to keep debris from the gate face and recess in order to allow the gate to open fully. The miter gate is opened and the barge pushes the debris into the lock. The barge conveys the debris through the lock and releases the debris into the river channel at the outlet. It is estimated that the barge is used 10 to 12 times per year. The debris clearing operation usually takes two to three hours.

When debris and drift are trapped upstream of the tainter gates, the lockmaster manipulates the tainter gates to flush the debris through the structure. A crane may be used to remove debris that collects in the gate support structure.

Approximately once every two to four years, the flood water stage overtops the lock and dam structure. Normally, sufficient lead time is provided to allow the maintenance crew to remove all handrails, signage, and other parts of the structure that will collect and/or retain debris during the flood. This is a major effort. Debris and cleanup operations begin during the falling limb of the flood hydrograph. Debris deposited in the overbank areas is collected by government contract personnel. Post flood cleanup may take several months to complete.

\subsubsection{Jonesville Lock and Dam}

The Jonesville Lock and Dam is located on the Black River Southeast of Monroe, Louisiana. Mr. Doug Prudhomme, Lockmaster, travelled to the Columbia Lock and Dam site to meet with the third author and discuss debris maintenance operational procedures. The Jonesville Lock and Dam consists of a hinge crest spillway, control crest with five tainter gates, and a lock 183 meters long and 25.5 meters wide. 
During flood stage, debris and drift accumulate on the upstream face of the dam. Debris is not routed over the spillway. Therefore, drift is guided to the lock and pushed through using a barge (with trash rack) or with two skiffs pushing a log ram. Bubblers have been installed at the lock miter gates to keep debris from impacting gate opening and closing operations. Occasionally, booms are placed upstream of the miter gates to divert debris from the lock chamber. High water events often require that a crane be used to clamshell debris from the structure near the tainter gates.

High water events (flood levels) occur two to three times per year. When high water is predicted, the rails along the lock chamber are removed. Debris is frequently caught in the pipes, cables, and motor pits in the lock chamber. Debris removal is often performed using a spike pole when maintenance personnel are available.

Appendix D illustrates a typical debris jam in the Jonesville Lock (March 21, 1995). Drift has been observed to nearly fill the 183 meter lock.

\subsubsection{J. H. Overton Lock and Dam}

Mr. Fred Pittman, Lockmaster of the J. H. Overton Lock and Dam, traveled to the Columbia Lock and Dam site with the third author to discuss debris management operations. The J. H. Overton Lock and Dam was constructed in 1987 and is situated on the Red River. There is no spillway on the dam. The dam has not been overtopped during high water levels as in the way experienced at the other lock and dam sites. The dam crest is controlled by a series of tainter gates. The approach channel was constructed with submerged dikes in the upstream channel. The dikes divert flow away from the lock entrance. Thereby, debris is carried into the dam and tainter gates.

The vast majority of the debris is conveyed through the dam tainter gates. On occasion, one to 0.8 hectares of debris will build-up along the dam face and must be removed using a barge mounted crane. When debris collects at the miter gates to the lock structure, bubblers are operated to suspend the debris away from the gate. The miter gates, in sequence, are operated and a "mule" barge with a rake conveys the drift through the lock. Debris is continually caught in the sidewall ports of the locks and spike poles are used to free this debris.

\subsubsection{Summary}

Each lock and dam either flushes the debris through the tainter gates, over the spillway, or through the lock chamber. Booms or dikes are routinely used to divert debris to the desired area for 
conveyance through the dam. "Mule" barges, or similar apparatus, are employed to guide drift through the lock chamber. Cranes are used for specialized debris removal. Debris management and/or removal_operations are considered a portion of routine operations and maintenance. Appendix E illustrates the extent of debris accumulation that can occur during an average flood season.

\subsection{St. Louis District}

On November 8, 1995, the third author met with Mr. Billy Arthur in the St. Louis District Office. The discussion focused on his knowledge of debris problems and management in the district. Mr. Arthur indicated that nearly all problems addressed in the district office related to lock and dam operations on the Mississippi River. Debris management is the responsibility of the lockmaster. Financial resources are not directly allocated for debris/drift operations. Debris is considered a part of the routine maintenance and operational budget. Emergency funds can be allocated on an "as needed" basis.

The majority of the lock and dam operational problems are related to ice jams, ice breaking, and ice damage. In comparison, debris is a minor concern. Most of the District efforts have been aimed at the design and installation of bubbler systems employed to keep debris away from the miter gates during opening and closing operations.

\subsection{Louisville District}

On November 9, 1995, the third author travelled to Louisville, Kentucky, to meet with members of the Louisville District Office. Discussions were oriented toward debris problems at reservoirs and at lock and dam operations. Mr. Rick Morgan and Mr. Gene Allsmiller were the principal contacts.

\subsubsection{Reservoir Operations}

Buckhorn Reservoir located in east Kentucky was the only reservoir the staff considered having debris concerns. Buckhorn is a run of river dam that spans the river valley. Debris is not passed over or through the dam. A boom is placed in front of the dam intake structures. Prevailing winds push the debris toward the abutment of the dam adjacent to a boat ramp. The boom is periodically retrieved thereby directing the debris to the shore line. A crane is employed to retrieve the debris and stack it along the shore. The debris is cut, piled, and burned on a periodic basis. 
On occasion, debris becomes water logged and floats under the log boom. This debris will enter the intake tower and jam. A diver, in conjunction with a barge-mounted crane, is then needed to clear the debris from the intake. The diver is used every two to three years.

\subsubsection{Lock and Dam Operations}

The Louisville District supervises 14 lock and dam operations ( 8 on the Ohio river, 2 on the Green River, and 4 on the Kentucky River). The size of each lock and dam varies considerably. Most of the operations were designed to pass major flood events without overtopping. All operations attempt to flush debris through the lock and/or dam. Two items were noted that were unique from other lock and dam operations and warranted citation.

Markland Lock and Dam is located on the Ohio River 531.5 miles below Pittsburgh, Pennsylvania (see Appendix F). The right abutment contains an intake for five hydro-electric power units. During spring runoff and high water levels, a large debris build-up occurs (no area estimate) at the hydro-power intakes. Debris removal is performed with booms, tainter gate manipulation and flushing, and crane removal. This is the only lock and dam with operational hydro-power capability. Extensive care is taken to protect the hydro-power units from debris clogging and build-up.

Circumstances were noted under which debris was identified as disrupting barge operations. When large debris build-ups occur, towboats have reported that debris fouls the engines and/or rudders. Situations were cited where the towboat and/or barge impacted the dam and/or lock chamber, and in some instances sank. Specific documentation of these cases was not made available. However, cases exist in which debris was blamed for excessive damage to barges, towboats and, subsequently to the lock and dam structure. Repairs, cleanup, and/or remediation are considered events worthy of emergency or contingency fund allocations.

In August 1995, the Louisville District, Corps of Engineers, in conjunction with other Corps Districts, conducted a study of debris accumulation for Ohio River lock intakes. The memorandum recording the findings of the study is presented in Appendix G. The report concluded that the amount of debris accumulation around intakes depends on the orientation and location of the locks, and the clearance between the inverts and river bottom. Debris routinely enters the lock chamber and becomes jammed in the side ports, pipes, cables, and motor wells. Maintenance and debris 
removal is not routinely performed. The Corps is proposing a modification to lock design that will impact lock filling time and potentially impact debris build-up in some locations of the chamber. A model study is being performed by the U. S. Army Engineer Waterways Experiment Station on the proposed lock modification. The results of the study are not available at this time.

\subsection{Drift Management at Bluestone Dam}

The following information comes from the report by Fripp et al. (1996). Bluestone Dam, West Virginia, was constructed in 1935 for hydro-power and flood control on the New River, Kanawha River and Ohio River. In the 1940s changes in the operation of the dam resulted in the conservation pool elevation being reduced by 24.5 meters which left a trash chute, constructed for the original operation plan, unusable. As a result, drift and debris could no longer be passed through the dam at flood flow and material therefore had to be released at low flows.

The amount of material that collects during a storm event can be as much as 12.5-20.25 hectares and this had a adverse impact upon recreation and environment below the dam.

Complaints from the public resulted in the authorisation for the Huntington District of the Corps of Engineers to develop a solution to the problem. The alternative management solution has centred around trying to reproduce the natural drift and debris flow in the New River, by releasing the debris that enters the lake during a high inflow event. The study centred on observations of the downstream movement of debris during various flow events. Based upon these observation a target flow of $1132 \mathrm{cms}$ has been chosen as the minimum flow required to avoid snags from forming downstream. As a result, three alternative high level intake structures have been proposed :

1) Utilisation of an existing sluice to pass material

A small cross sectional area, and zero slope on the sluice through the dam make it highly likely that debris will clog in the sluice, which will also compromise flood control capacity. This option has therefore been rejected.

2) Utilisation of an existing penstock to pass material

There are six hydro-power penstocks that could be used for debris passage. This option would, however, necessitate the construction of a chute to carry the debris to the downstream stilling basin. Debris exiting the chute would be pushed towards the channel right bank where it would accumulate. In order to deflect the material into the main flow, a dike or debris boom would, 
therefore, also need to be constructed. Because of the problems foreseen with this option the third possibility was reviewed.

3) Passage of material through a constructed sluice in the centre of the dam

This involves constructing a new intake tower and 3 by 2.5 meter sluice near the centre of the stilling basin, see figure 2.2. This option includes the positive features of the penstock and sluice options and none of their negatives. This option was therefore selected.

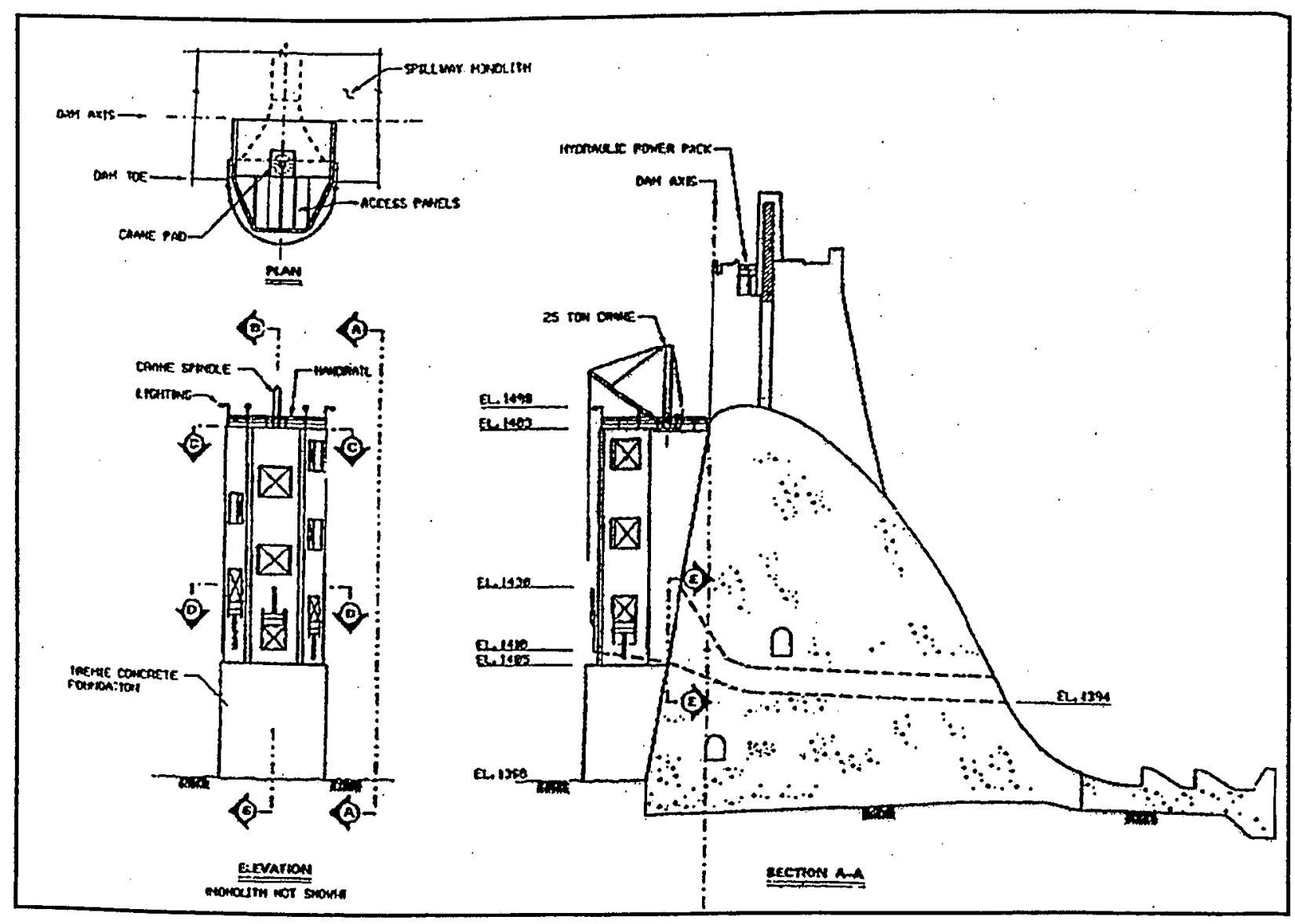

Figure 2.2 : Bluestone Dam proposed intake structure (from Fripp et. al., 1996)

The designed intake structure is a three sided tower on the upstream face of the dam, with six inverted 10 by 10 foot sluice gates, one inverted 2.1 meter by 2.1 meter sluice gate and one 2.1 meter by 2.1 meter gate. The roof of the structure will hold a 15 ton crane to service the gates and aid in the removing of debris if clogging occurs. The 3 by 3 meter gates and one of the 2.1 by 
2.1 meter gates are designed for the discharge of debris. The other 2.1 by 2.1 meter gate will provide extra flow to drive the debris material through the sluice and is referred to as a "kicker gate". The placement of the gates allows a continuous release of debris from a pool elevation of 452 meters to 433.5 meters. The kicker gate can pass small debris between elevations of 433 and 430.5 meters. Two barges will also be used to remove hazardous material, and to drive debris towards the intake structure. Personnel on the barges will also be able to remotely control the gate operation to optimise the drift and debris passage.

The structure described in this report is innovative as far as debris passage is concerned and can be considered as state-of-the-art. The research described demonstrates that rigorous research, at the design stage, of alternative strategies will help provide the best possible solution for alleviate debris build-up at hydraulic structures.

\subsection{Clover Fork Tunnel Diversion Project}

Martin (1989) describes a physical model analysis project to asses the design of a flow diversion tunnel with respect to optimum flow pattern and the potential for clogging of the tunnel entrances by debris. A diversion project has been proposed to divert the flow of the Clover Fork River, Harlan, Kentucky, around the central business district to provide the required standard of flood protection. The catchment is characterised as, "having a 104 square mile drainage area, with a large supply of potential debris upstream of the proposed tunnel, in the form of dead brush, trailer homes, trash, stockpiles of logs from clearing operations and input of riparian trees along reaches of unstable channel", (Martin, 1989).

The main aim of the study was, to evaluate the adequacy of the proposed tunnel entrance designs to pass debris in order to maintain the design freeboard.

A 1:30 scale physical model was constructed, reproducing approximately 610 meters of the natural channel upstream of the entrance and 137.25 meters of the 590 meter long tunnels. Seven approach configurations were tested for efficiency of flow and debris passage. The testing method used was to introduce the scaled volume of debris, potentially available from the upstream watershed, (estimated from field observation), during the standard project flood hydrograph. Selected size distributions of debris were also tested to simulate different loading of twigs, branches, trunks and trailers. Plate 10 shows the original tunnel entrance design without modification of the portal. 
Plate 11 shows a test run of the model, using a modified tunnel entrance, with a project flood and debris load. Design performance was evaluated by observing the volume of debris accumulation at the tunnel entrance and the maximum water surface elevation in the approach area.

Conclusions drawn from the project include the following :

1) Transition sections from natural channel to entrance channel should be curved to prevent flow separation and eddying;

2) The approach configuration shown below in figure 2.3 a was highly effective in preventing blockage, because the radius allowed for debris to pivot into the tunnel;

3) Configurations shown in figures $2.3 \mathrm{a}$ and $2.3 \mathrm{~b}$ were the most hydraulically efficient for passing debris;

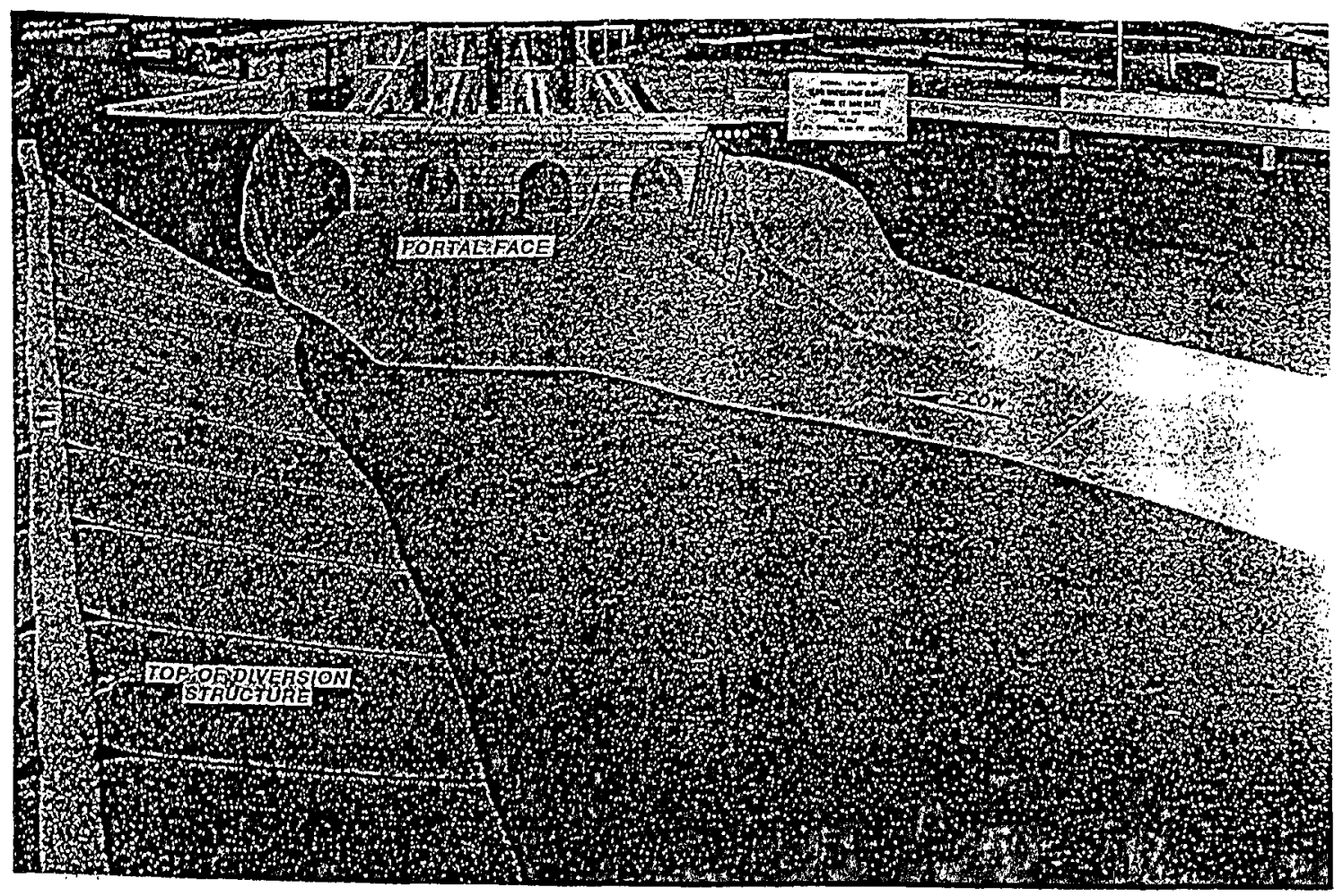

Plate 10 : Clover Fork Tunnel Model, Original Design Approach (from Martin, 1989) 


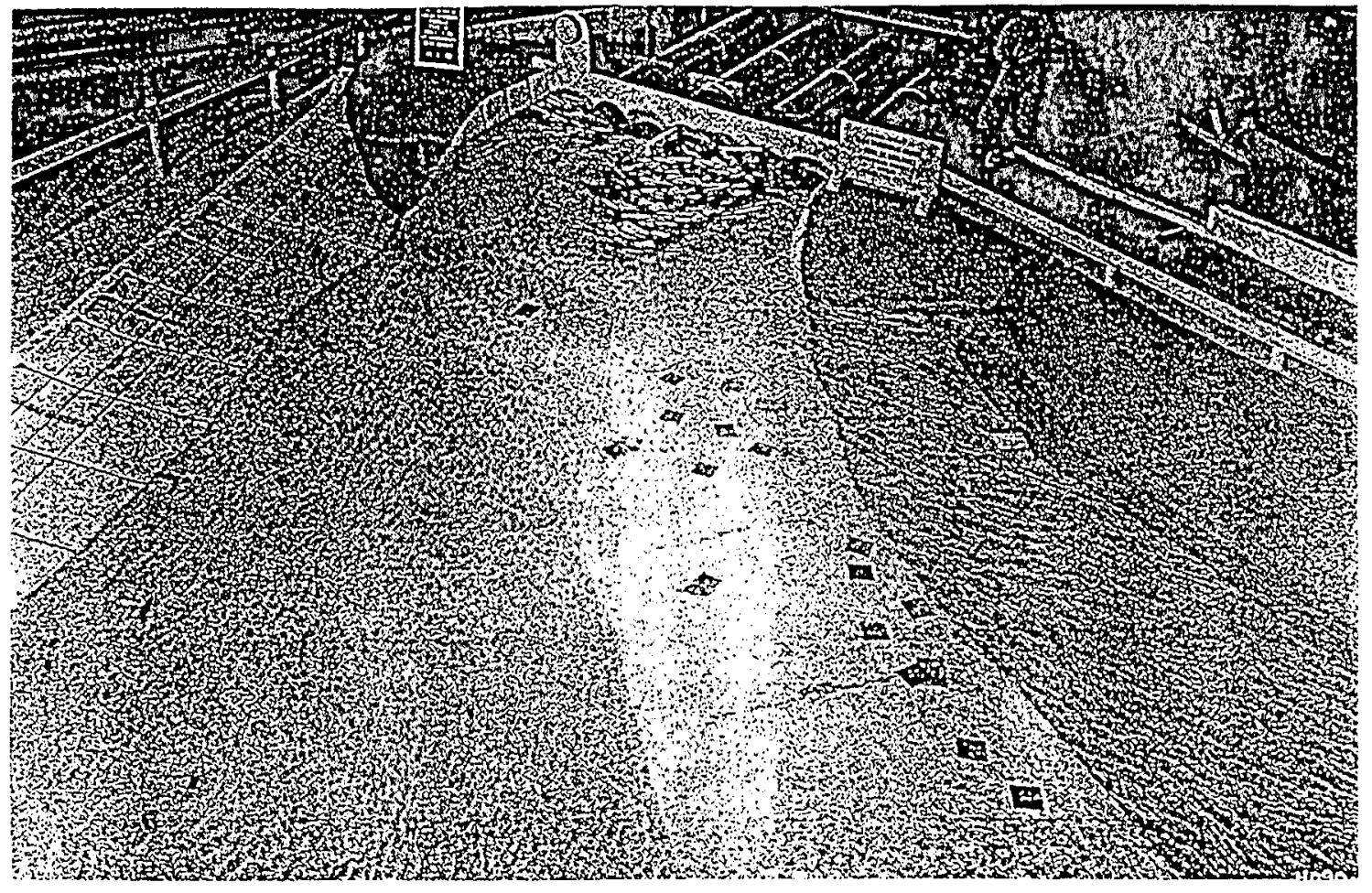

Plate 11 : Test Run Using Standard Project Flood and Debris Load (from Martin, 1989)

4) Blunt edges and flat surfaces at or below the water surface tended to cause turbulence and to gather debris.

5) Recommendations made following field investigations and observations of potential debris sources included the removal and re-siting of all floodplain housing and selective clearing of trees near the channel bank.

\subsection{Portland District}

On 15th - 16th July 1996, the third author travelled to Portland, Oregon, and met with Mr. Robert van der Borg, Mechanical Engineer, Operations Division. Our discussions focused on the debris and drift problems associated with the Columbia River dams and instream power generating operations. The Columbia River power complex is comprised of eleven dam and power generating sites extending up river approximately 596.6 miles from the Pacific Ocean. The third author travelled to and toured the Bonneville Dam project site. Bonneville currently has 18 power units. A summary of the dams and specifics to each site is presented in Appendix H. 


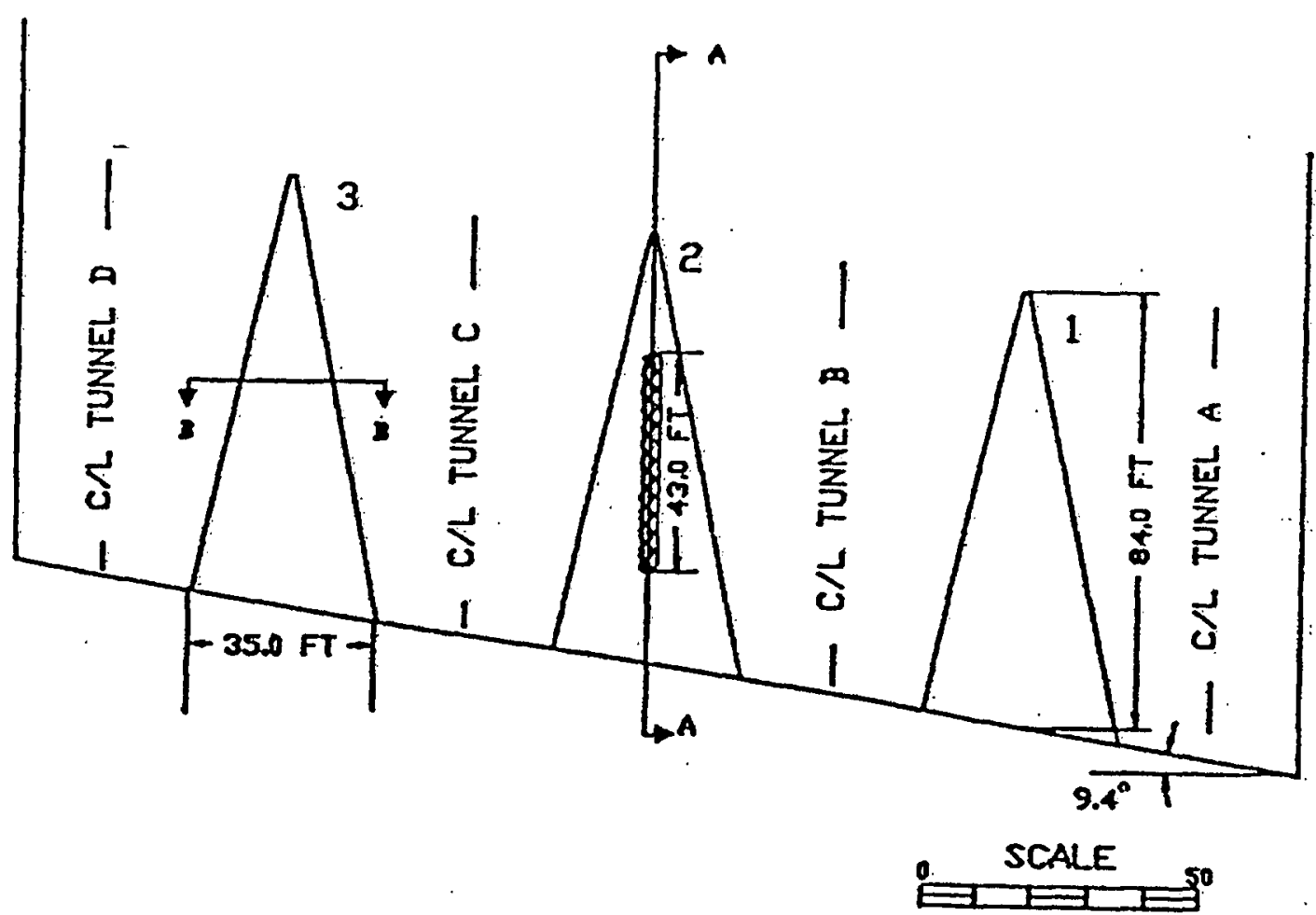

PLAN VIEW
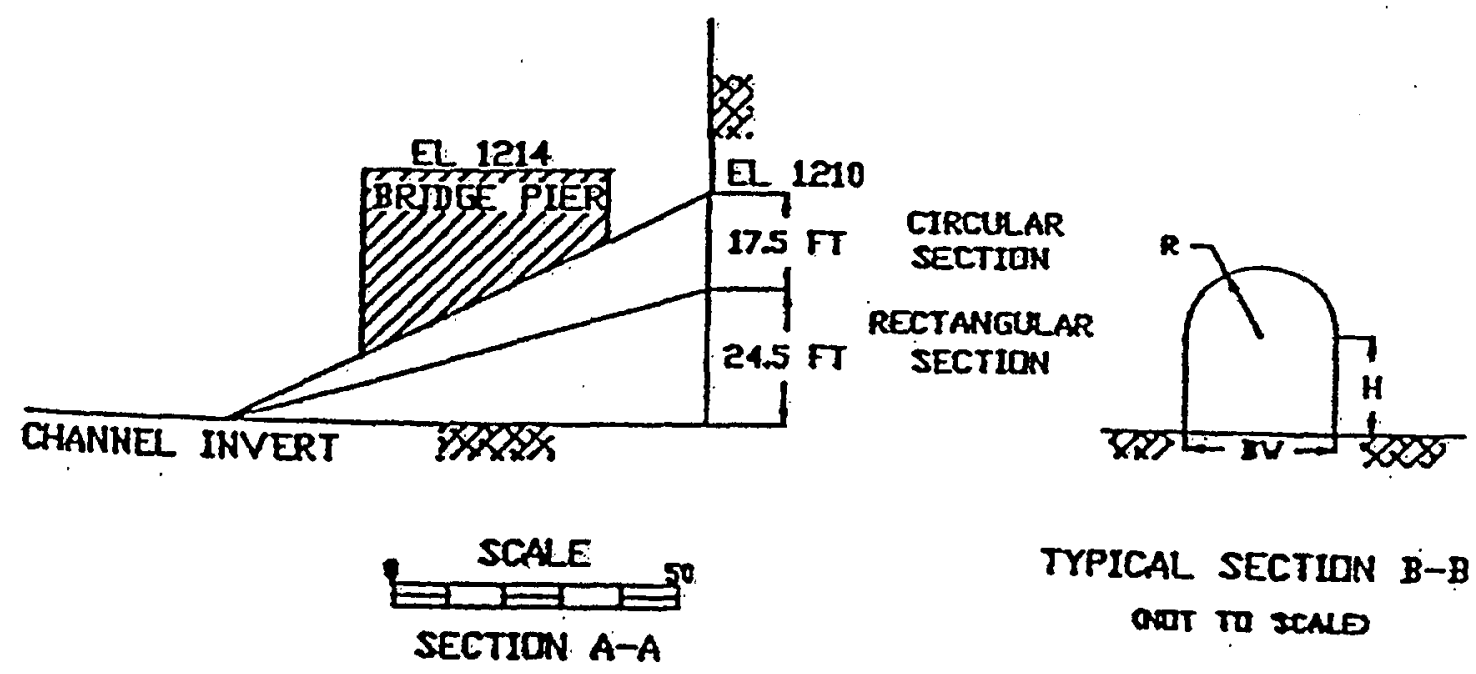

TYPICAL SECTION B-B ant TO SeND

Figure 2.3a : Type 6 Design Approach (from Martin, 1989) 


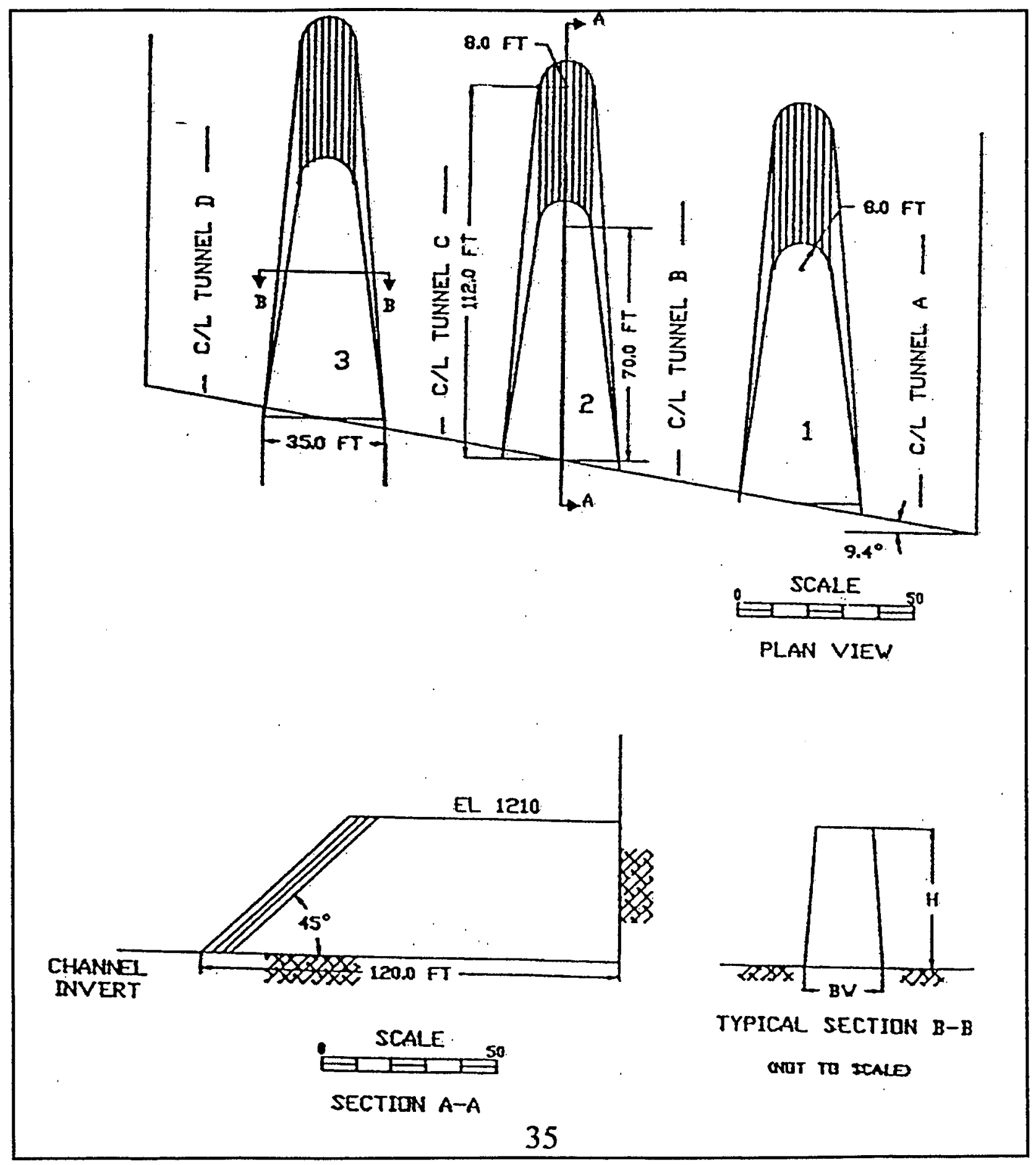

Figure 2.3b : Type 7 Design Approach (from Martin, 1989) 


\subsubsection{Bonneville Dam}

Debris management at Bonneville is accomplished through several means. For example, at Powerhouse 1, booms are employed in slack water areas to divert floating debris and drift toward active intakes. The dam structure has an ice and debris sluiceway traversing the upstream face adjacent to the turbine intakes. Screens are placed at the intakes to capture the debris. Through gate management, the debris is diverted into the sluiceway, transported along the dam face, and discharged through the structure at a port near the abutment. When the trash racks become clogged, a gantry crane (with clam shell and rack jams) clears the debris.

Powerhouse 2 does not have a sluiceway. Therefore, the turbine intakes are protected from debris with extension screens. A gantry crane with clam shell is used to remove the debris build-up. The screens are mounted in the spring (i.e., April) and removed in July. A debris pass through was installed at one abutment of the dam but is rarely utilized.

Bonneville has a navigation lock at the left bank of the river. Contrary to other Corps river operations, debris is not flushed through the lock. Rather, the debris is barged or towed out of the lock in the upstream direction, guided to the dam forebay, and discharged through the sluiceway system.

During spring runoff, $\log$ jams of 20 plus acres are not unusual. Managing the debris through the sluiceway system often takes several days. There did not appear to be a documented standard operating procedure. Debris management is performed and passed on through longevity of the operations and maintenance staff. Photographs of debris management operations at Bonneville Dam are shown in Appendix $\mathrm{K}$.

\subsubsection{High Head Dams}

Several high-head, flood control reservoirs are located in the Portland District (i.e., Blue River, Lost Creek, Detroit, etc.,). debris operations routinely use booms to guide debris from the primary storage area to shallow, side storage areas. When the water levels recede in the late summer, the debris is stranded and isolated. Cranes, loaders, and dump trucks are then used to gather and haul the debris from the reservoir site and disposed. debris is rarely flushed through the high head dam. Limited debris pass through occurs where tainter gates are available. 
Debris management consumes a significant amount of time and resources. However, debris management is not segmented from operations for budgeting purposes. Therefore, it is not possible to identify debris management from other operational tasks.

\subsection{San Francisco District}

Mr. John Azeveda, Chief of Operations, provided a tour of the navigation section debris clearing operations during the third authors visit of 1st - 2nd October 1996. The San Francisco district is responsible for providing safe shipping/navigation lanes throughout the bay area. The district coordinates with the U.S. Coast Guard, U.S. Navy, shipping and private industries to clear debris throughout the bay. Appendix I presents a map of the units' area of responsibility.

The debris management program (hazard collection) is traced to a seaplane accident. In June 1942, Admiral Nimitz, Commander in Chief - Pacific Fleet, was on his way to Washington, D.C. via San Francisco. While landing on San Francisco Bay, the seaplane struck floating debris, ripping the bottom of the craft open and causing it to capsize. The pilot was lost but Admiral Nimitz escaped without serious injury. Shortly after the incident, the Chief of Engineers directed the San Francisco District to initiate its collection program.

Debris is derived from the numerous tributary channels, degrading docking facilities, fires, shipping accidents, and other sources in the bay area. A fleet of three boats, harboured in Sausalito, California, are devoted primarily to debris collection. Two of the vessels, the Raccoon and the Coyote, are fitted with a crane and grapple claw for retrieving debris. The third vessel, the Grizzly is a smaller craft that can operate in shallow waters and is capable of towing debris. One crew is assigned to operate these vessels, the appropriate vessel is employed depending upon the daily missions. A technical description of the Coyote is presented in Appendix J.

The management and safety program removes approximately 400 plus tons of debris per year from the shipping lanes, docks, harbours, bridges, and adjacent areas. Debris is usually removed from the bay, transported on deck or in tow, and temporarily stored in an area adjacent to the fleet harbour. The debris is then loaded into containers and disposed (contract). In 1989, over 1700 tons of debris was removed from the bay. The extraordinary load was attributed to the 1989 earthquake. In addition to debris removal, the navigation section assists in disaster circumstances, performs hydrographic surveys, conducts inspections of breakwater jetties and similar structures, and assists 
interagency entities in specific safety missions as assigned. Although the primary mission is debris removal, a significant portion of the sections time is attributed to other missions. Photographs of debris control activities in the San Francisco District area are shown in Appendix K.

\subsection{Summary}

The Portland and San Francisco Districts have unique missions compared to the Huntington, Vicksburg, St. Louis and Louisville Districts. Debris management significantly impacts the daily operations (resources, personnel, mission) of these two districts far beyond those described for the four other districts. The Portland District must ensure continues power generation while managing navigation traffic, flood control, fish migration, and recreation. The San Francisco District must ensure safe, navigable shipping lanes within and adjacent to San Francisco Bay. Both operations require that debris and drift are appropriately managed to effectively accomplish their missions. Debris removal at Huntington, Vicksburg, St. Louis, and Louisville Districts is considered a small portion of their operations, and therefore isolating their expenditures exclusively for debris management is not warranted. However, the debris management program in San Francisco Bay is a high-profile, resource-demanding mission that cannot be easily hidden in an operations budget. Although debris management is a large portion of the Portland District operations, it is not isolated or highlighted in the district budget.

Debris management is a major component of operations for the west coast of the U.S. This was not the case for the central and northeastern areas of the U.S. previously visited. Debris management appear regional and mission oriented. 


\section{DEBRIS CONTROL SYSTEMS}

\subsection{Debris Retention Devices}

Perham (1988) suggested that floating debris can be collected and retained at dams using a number of different methods. These include:

A) Natural Features

- Key debris create jams which are natural stores of large quantities of potential floating debris.

-Debris also accumulates in small bays and sloughs when water currents and winds are directed favourably.

B) Fixed Structures

- Baffle Walls: These are vertical walls placed in front of an intake structure to intercept debris and thereby reduce impact loads on the intake debris rack. The wall extends several feet below the water surface. Trash rack cleaning and removal is performed in the space between the baffle wall and the intake structure.

- Dikes : Vane dikes can be used to guide debris into a holding boom or other collection structure. They may also be placed, for example, at China Bend on the Columbia River, to direct floating objects to the outside of bends and other locations where debris has a natural tendency to collect.

- Trash Struts : Trash struts are beams placed in front of an intake in an open framework so that large debris, such as whole trees, will not enter water conduits.

- Trash Racks : These are probably the single most important debris control device. The rack is faced with a series of vertical parallel bars to facilitate cleaning. The rack face usually has a slope to facilitate raking.

C) Moveable Structures

- Booms : A boom is a chain of logs, drums, or pontoons secured end to end, floating on a reservoir so as to divert debris. Figure 3.1 shows an example of a log boom

- Retention Boom : These are located and sized to hold debris inside or outside a defined area.

- Deflector Boom : A deflector boom is a boom of floating elements set at a steep angle to the river current. Debris is moved along the smooth face of the boom by the hydraulic drag of the 
current. Debris is then moved laterally to a holding pond from which it is eventually removed mechanically. Deflector booms are also used to route debris around structures such as docks and to keep it away from intakes.

- Nets : Nets are used to collect and hold debris.

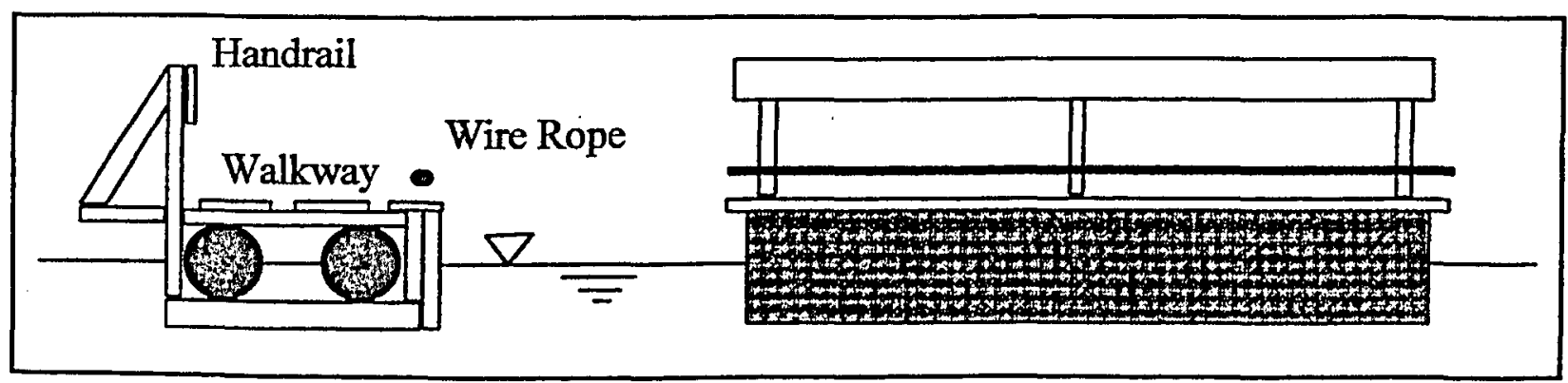

Figure 3.1 : Double Log Log-Boom

\subsection{Trash Racks}

Jansen et al. (1988) state that log booms should be the first line of defence against floating debris but suggest that trash racks are also required at most dam outlet structures. This is particularly true at surface intakes which are more vulnerable to debris build-up than deeply submerged ones. The optimum size of trashrack employed is governed by the limiting velocities and the size of conduit downstream of the intake and gates. Limiting velocities are themselves governed by head loss and blockage considerations and are normally limited to 0.91-1.21 ft/sec. Racks are commonly designed for operation with $50 \%$ clogging and must also be designed to be vibration-free to prevent metal fatigue. Vibration problems are discussed in more depth in section 3.3. Racks must also be provided with cleaning facilities to prevent excessive clogging and overstressing (see section 3.4).

There are two basic trashrack types. The first uses a concrete or metal frame to support a metal trashrack commonly constructed from flat steel bars set on edge with a spacing of 49-228 $\mathrm{mm}$. This type of rake will trap small debris. The second design uses concrete trash beams which have relatively large openings and are designed to trap very coarse debris which would otherwise prevent gate closure or damage turbines. 
The US Army Corps of Engineers commonly use trash beams with openings not more that two thirds the width and height of the gate or other constricted section to protect deeply submerged flood control outlets. -

Fully submerged trashracks are favoured to minimise maintenance, but if this is not possible racks must be easy to remove to facilitate rust removal and repainting. At some plants racks are constructed from stainless steel although this is an expensive option. If racks are exposed to freezing, ice can be eliminated from the rack by an air bubbler system which circulates warmer water from a lower level in the reservoir.

Trashracks used at hydro-power plants must have special design features. Specifically, Johnson (1988) points out that, "The main concern for hydro-power intake design is how to maintain a high discharge coefficient and minimise entrance losses, while minimising the size, complexity, and cost of the entrance structure with its associated gates, bulkheads, accessory equipment, and trashracks". Hydro-electric power stations depend mainly on beam-type trashracks for protection of turbines. Mesh screens are used only in special cases where removal of smaller trash is necessary, or where fish are to be protected from entering the intake. Additional protection is often provided by the use of floating $\log$ booms and skimmer walls.

\subsubsection{Constructional Features of Trash Racks}

Trashracks at hydro-electric power stations consist of vertical or slightly inclined steel bars placed parallel to one another and spaced uniformly to permit the use of raking equipment. Bars are supported by horizontal supports and the racks are usually assembled into panels to facilitate removal for maintenance. Trashracks are ordinarily constructed from mild carbon steel although more expensive wrought iron, alloy-steel and stainless steel are used at some locations. Johnson (1988) notes that model tests have shown that semi-circular trashrack seats reduce intake energy losses.

At low pressure (low velocity) intakes racks are usually set on an inclined plane of between $15^{\circ}$ and $45^{\circ}$ and extend from the bottom of the inlet structure to above the water surface. This inclination reduces head loss and also facilitates hand raking because submerged debris will tend to ride up the slope of the rack with the flow. Because mechanical rakes are now normally employed the inclination of trashracks is less important, although engineers still tend to prefer racks to be slightly 
inclined. Zowski (1960) also notes that, "....the vertical setting is used less frequently in European designs than in America.".

At deep intakes, which are submerged most of the time, the amount of debris that builds up is small and cleaning is required much less frequently. Racks are normally mounted vertically in guide slots so that they can be easily removed for maintenance, although it may be necessary to employ a diver to inspect racks which are set at very deep outlet structures.

Rack bar spacing depends primarily on the size and type of turbine to be protected and also the predicted type, scale and size distribution of the debris load. Bars should be spaced so that the clear opening is not greater than the smallest opening in the conduit structure or the turbine. In a Francis turbine the smallest clearance occurs in the runner between the discharge edge of one bucket and the back of the next. In Kaplan blade turbines the openings are larger and Zowski (1960) offers an approximate rule which establishes the maximum clear spacing between rack bars for Kaplan turbines as $1 / 30$ the diameter of the runner. At impulse turbines, such as the Pelton wheel, bar spacing must be considerably closer to prevent small twigs from clogging the nozzles. Zowski (1960) suggests using a rule whereby rack bar spacing should not be greater than $1 / 5$ of the jet diameter at maximum needle opening.

The maximum acceptable velocity through trash racks is determined by the type of intake, amount of debris build-up, method of cleaning and rack construction. Optimum velocities depend mainly on the amount of head loss that is economically permissible as compared with the area of trash rack. Velocities must also be correlated with rack design to ensure that there will be no serious vibration problems. At low head intakes design velocities are usually around $0.9-1.2 \mathrm{~m} / \mathrm{s}$, while at high head intakes velocities of 3-3.6 m/s are permissible if the racks are adequately designed to cope with the greater potential vibration.

There are a number of formula in use for determining head loss through rack bars. Kirschmer's equation (discussed by Zowski, 1960) is:

$$
h_{r}=K\left(\frac{t}{b}\right)^{4 / 3} \frac{V_{o}^{2}}{2 g} \sin \alpha
$$


where $: h_{t}=$ loss of head through racks (ft), $t=$ thickness of bars, (ins), $b=$ clear spacing between bars $(\mathrm{ft}), \mathrm{V}_{\mathrm{o}}=$ velocity of approach $(\mathrm{ft} / \mathrm{s}), \mathrm{g}=$ acceleration due to gravity $\left(\mathrm{ft} / \mathrm{s}^{3}\right), \alpha=$ angle of bar inclination to horizontal (degrees), $\mathrm{K}=$ factor depending on bar shape. See figure 3.2.

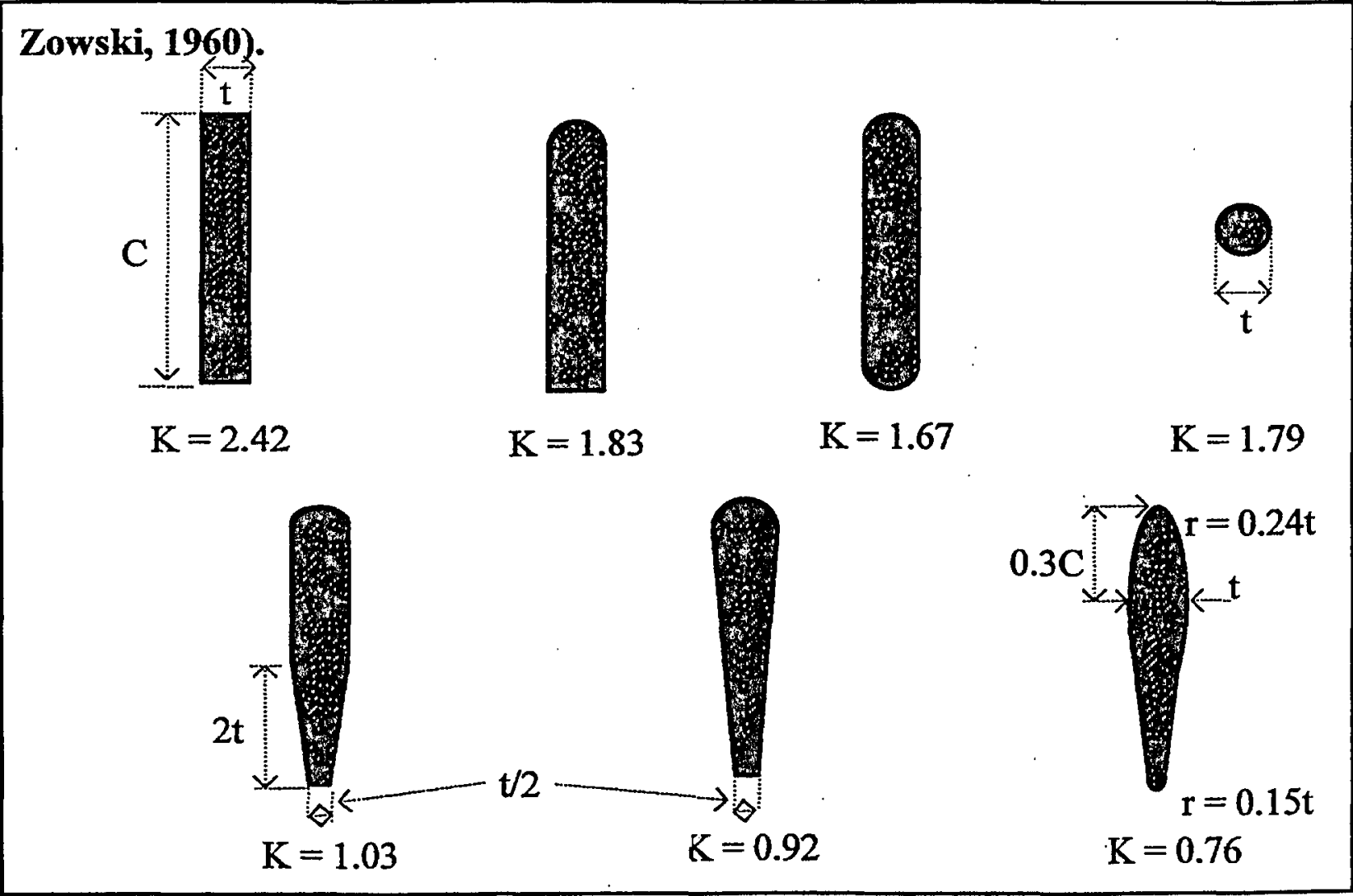

Figure 3.2 : Variables and $\mathrm{K}$ factor values for various bar shapes (modified from Zowski, 1960)

Zowski (1960) notes that laboratory tests in connection with a number of racks have shown this formula to consistently underpredict head loss by a factor of 1.75 to 2.0 . Also, the computed head losses apply to clean racks and so, to allow for partial clogging (assuming $10 \%$ of the rack will be obstructed), head loss should be increased by a factor of about 1.23 . Where severe clogging occurs (between $25 \%$ and $50 \%$ of the rack) this factor should be increased to between 1.78 and 4.0 . A variety of bar shapes are shown in figure 3.2. Flat bar ends are usually adequate, while the use of streamline shapes is seldom justified from an economic standpoint. From hydraulic 
considerations, however, bars should be as thin as possible although it is not advisable to use bars less than $9.5 \mathrm{~mm}$. thick to avoid damage from handling and debris impact. For deeply submerged intakes, bars not less than $12 \mathrm{~mm}$ thick should be used. The depth of bars is determined by structural requirements but to permit raking it should be made sufficient to provide $38 \mathrm{~mm}$ depth between the upstream face and back support struts.

Further analysis of head loss through rectangular-bar trashracks can be found in Osborn (1968) who developed equations which can be used to calculate head loss as a function of approach velocity and clear spacing between bars. For trash racks composed of bars with depth to thickness ratios $(d / t)$ greater than 3.0 the equation for head loss is determined by the equation:

$$
\Delta h r^{1}=\frac{V^{2}}{2 g}\left[\frac{(1-K)}{(K)^{7 / 3}}\right]
$$

where : $\Delta \mathrm{hr}^{\mathrm{l}}=$ head loss for long bar (deep-bar) racks; $\mathrm{V}=$ mean approach velocity; $\mathrm{g}=$ acceleration due to gravity; $K=$ ratio of flow area between the bars to the approach flow area. $K=b /(b+t)$ at $90^{\circ}$ to the flow; $b=$ clear spacing between bars; $t=$ thickness of bars. See figure 3.3.

For trash racks composed of bars with depth to thickness ratios less than 3.0 head loss is determined by the equation:

$$
\Delta h r^{2}=\frac{V^{2}}{2 g}\left[\frac{1.35}{(K) 7 / 6}-1\right]^{2}
$$

where : $\Delta \mathrm{hr}^{2}=$ headloss for short-bar racks.

Design loads on trashracks depend upon the water pressure imposed when the rack becomes heavily clogged by debris or ice. It also depends upon the relative importance of the installation, bar spacing and the provision for frequent cleaning. If the plant is remotely-controlled and unattended, racks should have higher design loads.

Corps of Engineers hydro-plants, most of which are medium head with a large discharge capacity, are usually designed for a differential head of $3 \mathrm{~m}$. In the US Bureau of Reclamation, and also at many privately owned plants, trashracks at low pressure intakes with adequate flow area are usually 


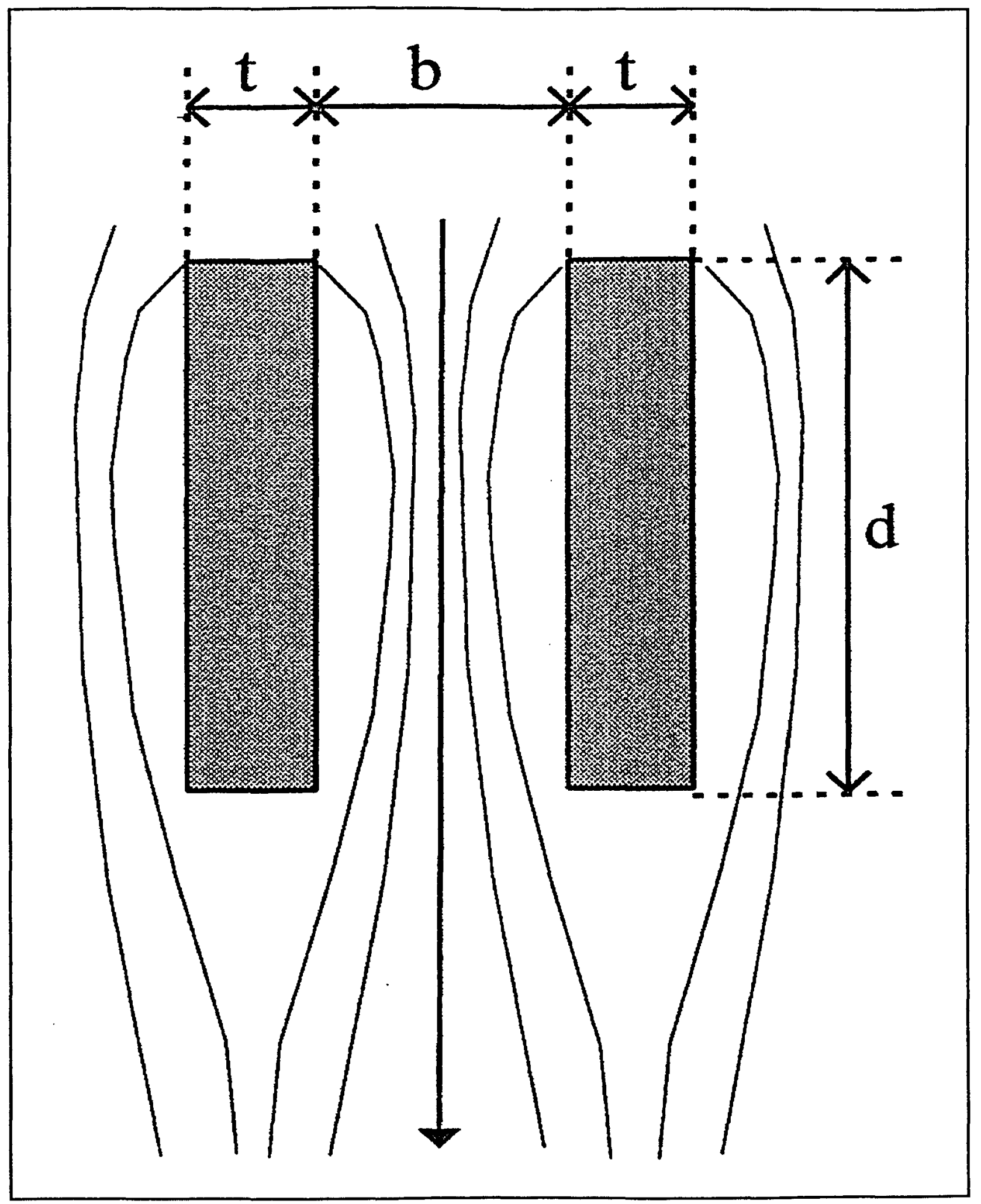

Figure 3.3 : Trash rack bar variables (modified from Osborn, 1968) 
designed to withstand a differential head of $6 \mathrm{~m}$ without failure. At high pressure intakes the Bureau of Reclamation designs the trashrack structure to withstand a load equivalent to one half of the head on the racks up to a maximum of 12.2 meters.

If trash includes large floating debris, impact forces must be considered. An approximate formula that can be employed to calculate the impact force of a $\log$ is :

$$
P=\frac{W}{g} \frac{V}{\Delta t}=\frac{W}{32} \frac{3.2}{0.1} \approx W
$$

where : $\mathrm{P}=$ impact force $(\mathrm{lbf}), \mathrm{g}=$ acceleration due to gravity. $\left(\mathrm{ft} / \mathrm{s}^{2}\right), \mathrm{W}=$ weight of $\log (\mathrm{lb}), \mathrm{V}=$ inflow velocity. $\mathrm{ft} / \mathrm{s}$ (usually 3-3.5 ft/s at low head plants), and $\Delta \mathrm{t}=$ time interval in which velocity of $\log$ is reduced to zero due to elastic deflection of rack bars (s), (usually about 0.1s for standard rack design).

Thus the impact force is approximately equivalent to the weight of the log for approach speeds within the acceptable range for low head plants.

Abt et al. (1992) assessed trash rack design for an inlet drop structure on a storm drainage channel in Security, Colorado. A 1:15 scale model of a portion of the system and trash rack were constructed and tested for hydraulic efficiency with varying rack slopes and degrees of rack blockage simulated using porous and non-porous debris. Design flows through the system were all supercritical. Slopes tested were $1: 2$ and 3:1 and it was found that the 1:2 slope tends to clog while the 3:1 slope has better self-cleaning properties for floating debris. Abt et al. (1992) noted that the traditional assumption of a factor of safety of unity with $50 \%$ blockage may not be conservative for trash racks as model results showed flooding with $41 \%$ blockage on a 3:1 slope in supercritical flow. They also pointed out that it may be a grave error to assume that all the debris load is floating because submerged debris, which lodges on the lower portion of a trash rack, can cause a serve flood potential.

\subsubsection{Vortices at Hydro-Plant Intakes}

Air entraining vortices at hydro-plant intakes can pull floating debris into the turbine, or onto the trash rack to cause rough turbine operation. Vortex formation is largely dependant upon the influence of site-specific geometry. This fact has precluded the development of generalised 
prediction relationships. Johnson (1988) notes, however, that the work of Blaisdell (1982) and of Gordon (1970) has produced the following equation which can be used to predict the potential for vortex development:

$$
\frac{S}{d}=C \frac{V}{\sqrt{g d}}=C F
$$

where $: \mathrm{S}$ = submergence required to prevent air-entraining vortex formation, $\mathrm{d}=$ penstock diameter, $\mathrm{V}=$ average penstock velocity, $\mathrm{C}=$ coefficient $(1.70$ for symmetrical flow approach, 2.22 for lateral flow approach, and $\mathrm{F}=$ Froude number of penstock flow.

It is recommended by Johnson (1988) that if the submergence proves to be inadequate a physical model study should be carried out, although note should be taken with the problems of model scaling. Johnson mentions that Hecker (1981) has presented guidelines to assist with vortex potential evaluation. Vortex problems can be alleviated using a number of structural measures including rafts, injector shafts (see section 1.7) and fixed lattice walls (Johnson, 1988).

\subsubsection{Vibration Problems at Trash Racks}

In a review of trash rack failures Syamalarao (1989) suggests the following factors should be considered in trash rack design :

1) Differential head across the rack;

2) Bar spacing;

3) Head loss at the rack;

4) Vibration response.

The last of these aspects is complex and can be subdivided into four areas of importance:

4a) Natural frequency of vertical and horizontal bars;

4b) Excitation or forcing frequency;

4c) Possibility of resonance;

4d) Possibility of fatigue caused by strong turbulence and buffeting.

The natural frequency of bars $\left(f_{n}\right)$ is estimated by the equation :

$$
f_{n}=\frac{\alpha}{2 \pi}\left(\frac{E I g}{w l^{3}}\right)^{1 / 2}
$$


where : $w=$ total weight of bar including that of the vibrating fluid, $1=$ unsupported length of the bar, $\mathrm{E}=$ Young's modulus, $\mathrm{I}=$ moment of inertia, $\mathrm{g}=$ acceleration due to gravity, $\alpha=$ coefficient dependant on the end fixings.

$\alpha$ varies from $\pi^{2}=9.87$, for a simply supported bar, to $4 \pi^{2} / \sqrt{ } 3=22.7$ for a bar fixed at both ends. The longer the bar the smaller is the value of $\alpha$. Continuously supported bars can have a $\alpha$ value of up to 39.48 .

Syamalarao (1989) goes on to give details of eleven documented trash rack failures at various plants in Europe and the US, describing the trash rack form, bar dimensions and commenting on the type and severity of failure (figure 3.4). Syamalarao concludes that trash rack units at the bottom of intakes and near side walls are most susceptible to damage, with failure types including breaking, twisting or complete removal of vertical bars, loss of horizontal support bars due to breakage at the point of welding to the vertical bars, and failure of trash rack anchor bolts.

Jansen (1988) discusses trash rack vibration problems at the Edward Hyatt Powerplant, USA. Here trashracks at the dam outlet suffered from vibration problems due to the von-Karmon vortex-street effect whereby turbulence is created in the wake of flows passing around a bar. Tiny vortices are rapidly formed and shed first on one side of the bar then the other, regularly alternating back and forth. This effect can set the bar in motion and may cause rapid failure by fatigue. To alleviate the problem lateral stabilisers made of butyl rubber were placed between the bars and diagonal bracing was added. As a consequence, the magnitude of force on the bars was reduced from $2.15 \mathrm{~g}$ to $0.1 \mathrm{~g}$ thus ensuring that the trash rack would not fail through fatigue.

Sell (1971) also examined trashrack design considerations with special reference to vibration problems and discussed the various components of bar vibration in detail. The author concluded that, "If trashracks were to be designed purely for vibration considerations bars would be as nearly square as possible...... This type of trashrack would have a high head loss which is normally not desirable; therefore, the problem is to keep head loss at a minimum, while avoiding a resonant condition".

\subsection{Removing Floating Debris}

Removal of accumulated trash is usually accomplished by raking. In the past this was mostly done by hand, but at present hand raking is only performed at small capacity low head plants. In large 


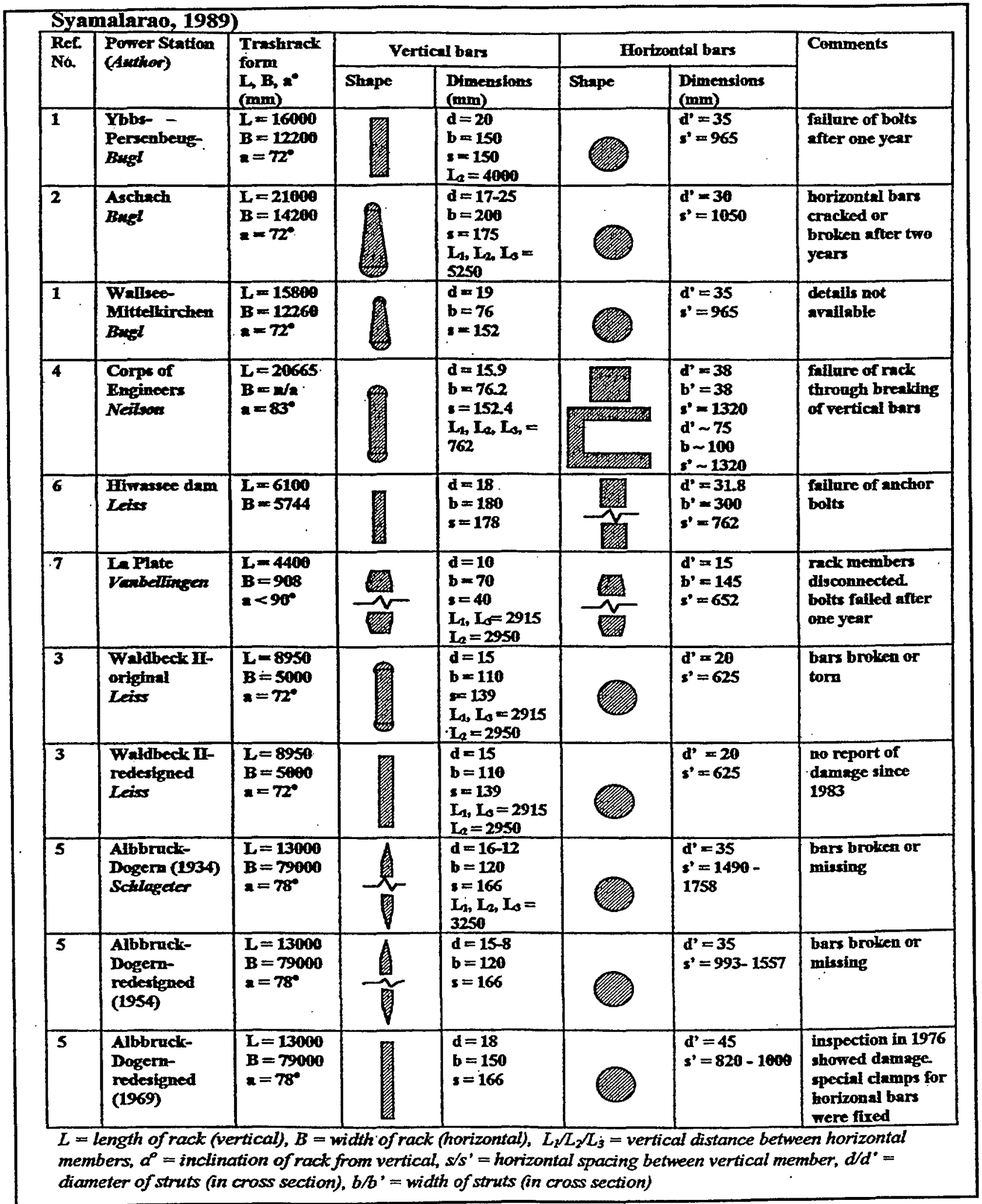

Figure 3.4 : Details of Trashracks which failed during operation (from Syamalarao, 1989) 
modern hydro-plants trash is removed almost exclusively by mechanical rakes. Mechanical rakes operate on the principle of lowering a raking element in front of the trash bars to dislodge debris and then raising it up the rack face to a point where the accumulated material can be unloaded. Rakes are usually lowered and raised by motor-driven hoisting mechanisms using steel cables. There are two main types of mechanical rake; unguided, and; guided.

\subsubsection{Unguided Mechanical Rakes}

These have wide-face wheels which travel directly on the rack bars, and keep the rake teeth the correct distance from the racks. The rakes depend upon rack inclination, weight and the back pressure of water to hold them against the rack face. The width of unguided rakes is not dictated by the trashrack span but by the volume and nature of debris which accumulates. Rakes are commonly between 1.8 and 3.7 metres wide. The operating advantage of unguided rakes is their ability to pass over stubborn obstructions without becoming jammed. The rake can also serve as a grapple for large logs. The lack of guidance may become a disadvantage, however, if there are strong transverse currents at the intake which may dislodge or even overturn the rake. Unguided rakes are not suited to deep intake trashracks where the bars do not extend above the inlet structure. In such cases removable metal or wooden panels are needed which extend from the top of the trashrack to the deck in order to prevent trash from falling from the rake as it travels upwards to the unloading point. The cost of unguided rake installation is generally less than for a guided rake because guiding mechanisms are not required and the rake width can be made smaller.

One example of an unguided rake is the Leonard-type rake which is commonly used in the USA. This rake has a series of teeth on an axle which rotates through $90^{\circ}$ from vertical to horizontal when the rake reaches the bottom of the rack so that debris is not pushed to the bottom as the rake moves downwards. At the top of the rack the rake is guided to the unloading position by a curved apron which prevents the loss of debris. This apron also supports the rake as it traverses from one bay to the next. Plate 12 shows a Leonard rake supported on a combined hoist, trash car and apron. Another example of an unguided rake is the Glenfield plow which plows through the debris on its downward travel and on the upward travel the debris thus dislodged is caught in the basket formed by the upper part of the rake. Plate 13 shows a plow rake suspended from an intake gantry crane. 


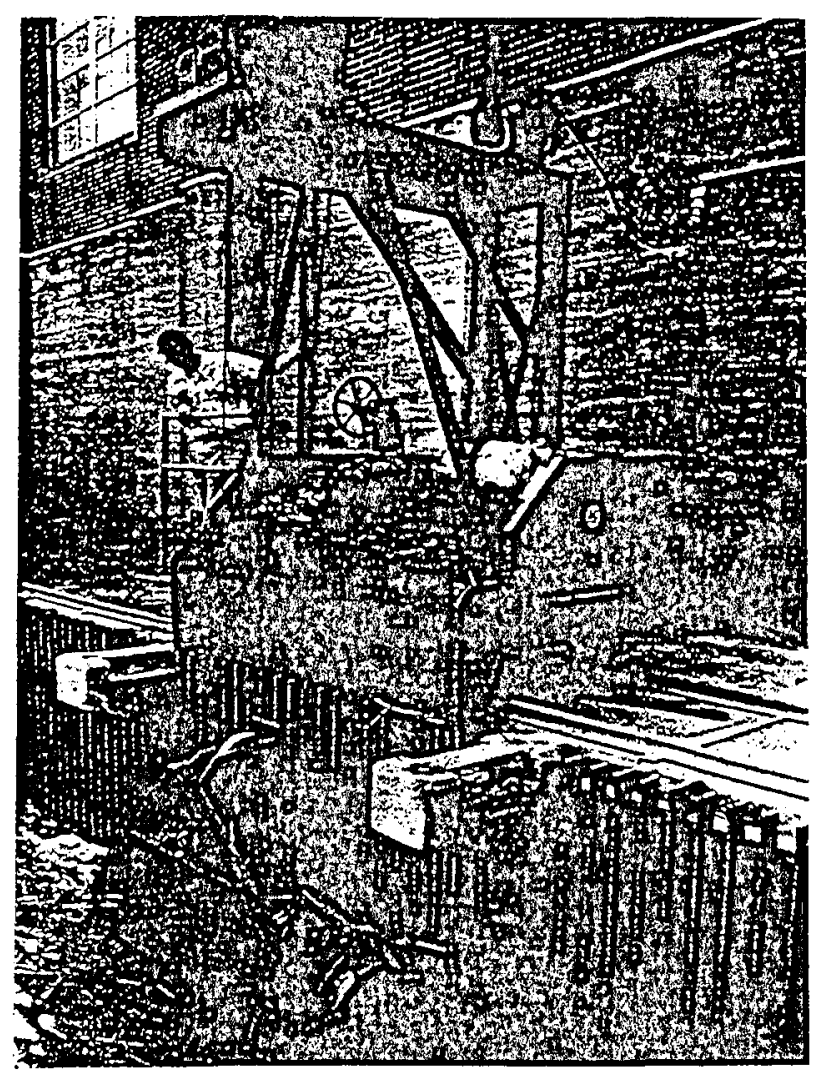

\section{Plate 12 : Leonard type rake with combined hoist, trash car and apron (after Zowski, 1960)}

\subsubsection{Guided Mechanical Rakes}

This type of rake requires guides which are usually made of steel embedded in the concrete walls of the intake piers. The rake is guided by rollers or sliding blocks which travel in the channel guides. One of the advantages of the guided rake is that it may readily be used on vertical racks and is not affected by strong transverse currents. Another marked advantage of the guided rake is that it is suitable for use in intakes where the trashrack does not extend up to the operating deck. Disadvantages are that the guides may become obstructed by debris and, under severe trash conditions, they may need considerable maintenance work. An example of a guided rake is shown in plate 14. This is a Newport News rake and consists of a frame with rollers which travel in guides and a pivoting raking element which is operated by levers linked to the sliding upper beam. The 


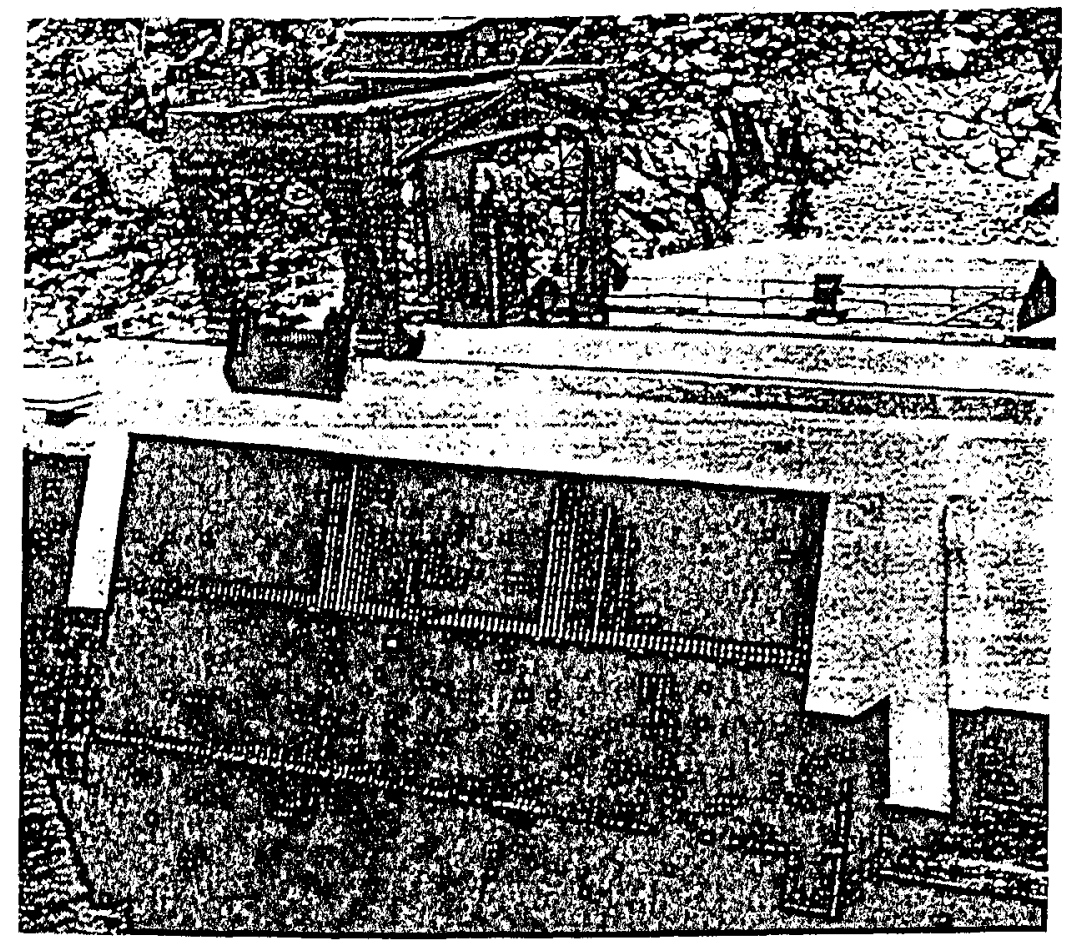

\section{Plate 13 : Plow rake installation (after Zowski, 1960)}

rake is lowered with the teeth pointing downwards and as the rake reaches the bottom of the rack the mechanical action of the hoist closes it so that the teeth project into the bar-rack spaces.

There are several methods of unloading debris from rakes. At many installations unloading by manual raking is the most effective method because of the complex nature of the debris. Some raking machines have automatic sweeps, however, which push the debris off the rake teeth when the rake reaches its unloading position. These devices are very useful where heavy loads of light debris such as leaves, weeds and twigs occur, but are less satisfactory for heavy debris such as logs. Disposal of debris from rack cleaning devices is performed by either sluicing or hauling it away in trucks.

Because of the operating limitations of mechanical raking devices, and their maintenance requirements particularly under severe trash conditions, some plant operators prefer to use more simple and rugged types of rake which can be operated by a gantry crane that moves along rails on the forebay deck from one end of the plant to the other. Shoreline rakes may also be employed to collect debris that accumulates along the shoreline, using a special crane-operated dragline. The 


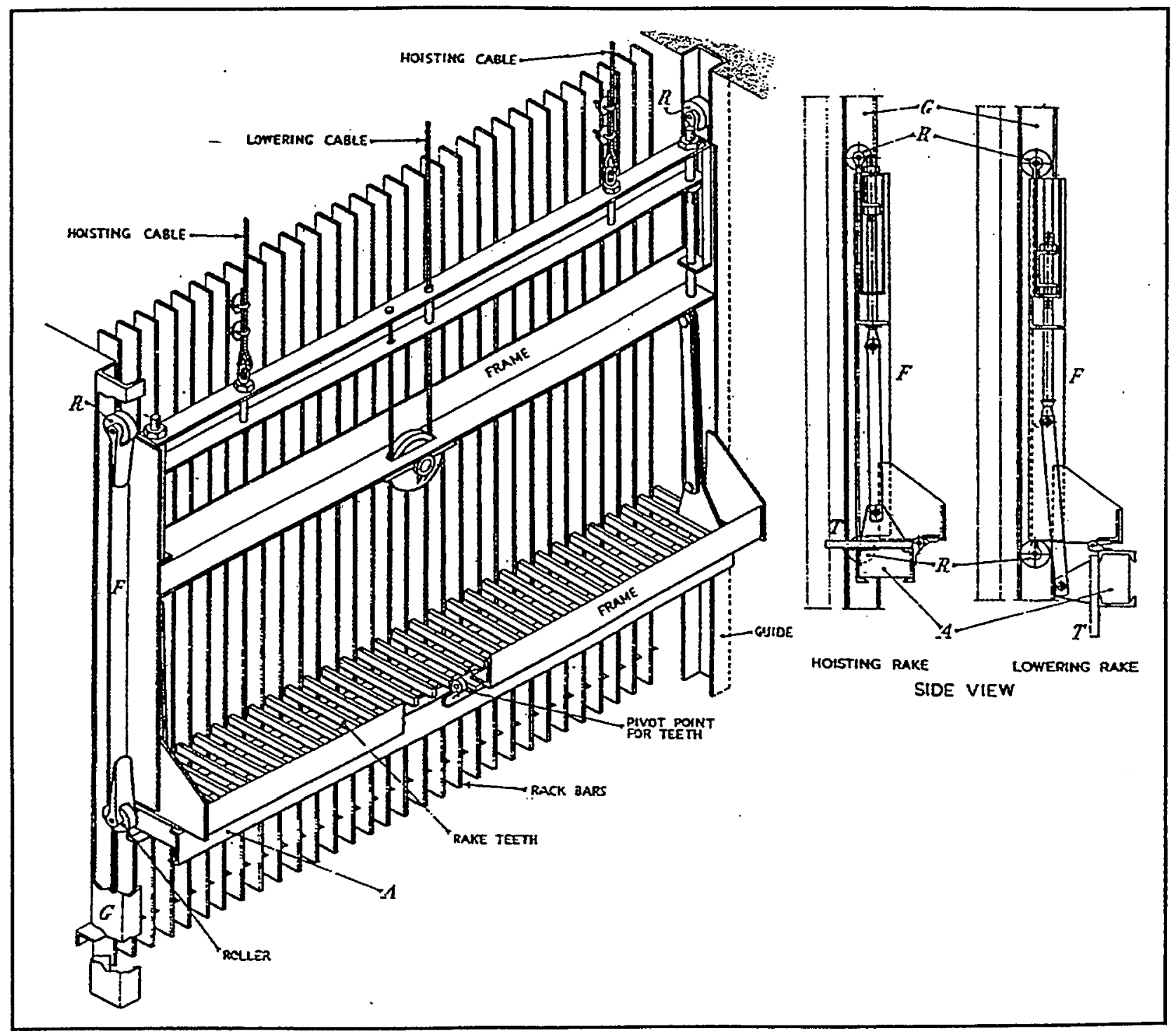

Plate 14 : Newport News mechanical guided trashrack rake (after Zowski, 1960)

debris can be collected from around the anchor site into one spot and a set of log tongs or a clamshell used to lift the debris into a container.

A variety of other debris removal mechanisms can also been utilised (Perham, 1987) These include:

1) Cranes and Hoists : a wide variety of cranes and hoists, in conjunction with buckets, tongs and grapples can be used to remove debris from the face of dam walls.

2) Loaders : In the situation where floating debris is deflected by booms into holding areas that can be drained, debris can be loaded into trucks using crawler or wheel-type loaders. 
3) Conveyors : There are several types of conveyor that can be used to lift material from the water to a disposal unit. An appropriate conveyor is the flight conveyor which has scrapers mounted at intervals, perpendicular to the direction of travel, on endless power-driver chains operating within a trough. The main problem with a conveyor is feeding material into it. A variety of techniques have been used to overcome this however, including high pressure nozzles to push debris, propellers to draw water through the conveyor, and hand labour using pike poles.

4) Boats : Multipurpose workboats can be used to tow roundup booms, shove debris along a boom or flush it away from some location using propwash. There are also a number of specially designed debris collection boats in operation in the USA for example, the USAED boat used in San Francisco Bay. This boat has twin bows with a large space in between where a chain net is positioned as a scoop. An onboard crane is used to set the net filled with debris on the deck and to replace it with an empty one.

5) Travelling Screens : A travelling screen is a flexible screen surface that moves like a conveyor belt, or is in the form of a rotating, perforated drum. The screen blocks the water intake so that water must flow through it. The screen moves slowly up into a location where the accumulated debris is removed by water jets. The device is used to good effect in English land drainage and pumping systems, which carry a lot of grass and small debris.

6) Air Bubblers : An air bubbler is used to remove small-sized debris from vertical trash racks at the Wider Dam, on the Connecticut River, USA. It consists of a horizontal brass pipe with multiple holes, anchored at the bottom of each trash rack and fed from a compressed air tank. The intake water flow is stopped prior to the air being discharged and the debris rises to the top where it passes over a submersible gate.

If no special cleaning devices are provided, but some floating debris occasionally collects at racks it is good practice to remove it before it becomes waterlogged and sinks to the bed. Debris can be towed along the dam face to a suitable location on the shore where it can be piled up and burnt. Many debris management techniques have been developed for site specific reasons, such as the continuous removal of debris as it is carried to a dam by high spring flows because when flow slackens the prevailing wind can blow the debris all over the pool. 


\subsection{Debris Passage}

Debris can become a hazard to the operation, if not the integrity, of a dam. At many hydrodams, to avoid problems of this nature the appropriate gate or gates are opened to the necessary height or depth to send the floating debris downstream.

- Dam gates: Dam gates can be raised to flush debris downstream provided this action does not cause scour downstream of the dam. However, because debris floats on the surface, gates in general, must be raised a substantial distance to achieve the water velocities needed to take the debris down and through the opening.

- Logways/sluiceways: Many dams in areas where logging is an important industry, such as the north-western United States and Canada, will contain logways and sluices for passing logs and pulpwood through the structure. The logway is mainly a sloping flume through which water flows to carry the logs to a point below the dam. The passage may contain a conveyor system.

\subsection{Disposing of Debris}

\section{a) Useable Materials}

- Structural Materials: Some logs may be large enough for structural applications, if the logs are in good condition.

- Firewood: In general, a fair portion of debris can be dried and cut up for firewood, but the extent of its usefulness depends on how clean it is.

b) Unusable Materials

Useless debris should be discarded in a locally acceptable manner.

- Burning. Debris may be burnt on land or on the water. Debris can be brought ashore by workboat and bag boom or similar scheme where it is lifted out and piled on the ground to be burned. Floating debris can also be burned on water, where permitted, using a barge and an aircurtain burner.

- Burial: If burning is prohibited by local regulations, disposal can be accomplished by burial in suitable locations near the collection sites. Debris should never be placed in areas where it may be carried away by stream flow or where it blocks drainage of an area. 


\subsection{Debris Passage at Spillways}

\subsubsection{Recommended Practice to Prevent Obstruction}

In a discussion of spillway design and construction, Scherich (610) in Jansen (1988) lists "reservoir trash load" as one of the data requirements to support the hydraulic design criteria for effective spillway design. However, spillway operation with a floating debris load is often overlooked or considered only as an afterthought in spillway design, especially in ungated structures. This has, in at least one instance (see section 1.5), resulted in the failure of a spillway to convey the design flood resulting in dam overtopping.

Methods for overcoming debris problems at spillways include the use of floating or fixed booms, surface discharge chutes at deep sluices (ICOLD Bulletin $58,1987,119)$ and a variety of trashracks and raking devices. Floating ice in dams is dealt with in a similar way. Ice build-up in front of gated spillways it is often broken up by an ice breaker boat and with broken ice subsequently guided to special openings through which it is discharged. Vertical lift or flap gates will allow discharge of ice in a nappe up to $2 \mathrm{~m}$ thick, but when the quantity of ice to be discharged increases too rapidly gates must be raised to their full height to completely clear the opening (ICOLD Bulletin 58, 1987).

\subsubsection{Theoretical Research}

Godtland \& Tesaker (1994) examined the potential for debris clogging at spillways on two dams in Norway. In both cases the spillway was of the fixed overflow type with a bridge supported by piers along the crest. As a result of the project the bridge on top of one of the dams was removed in 1991. Model tests were carried out to determine under which conditions debris tangles may cause clogging of spillways with and without a bridge superstructure and to determine the anchor forces required to hold back debris from the dams crest by trash booms and similar retaining devices. The following approximate guidelines were derived from the tests:

- pillar distance of bridge structure on top of the spillway should be at least $80 \%$ of the length of the arriving trees;

- vertical free opening between the crest and superstructure should be at least $15 \%$ of the tree length;

- downstream height of the sill should not exceed $1 / 3$ of the tree length if a superstructure is present. Otherwise a high downstream wall is usually better for passing the trash than a low wall; 
- if not obstructed by any superstructure, tangles and single trees may be withheld along the crest until the overflow level reaches near the root diameter of the arriving trees, about 1/6 of the tree length;

- most (debris) tangles will pass a crest without superstructure when the overflow depth reaches $10-16 \%$ of the height of trees forming the tangle. Where a superstructure is present, with pillar distance at least $110 \%$ of the tree length, most tangles will pass when overflow height reaches $16-20 \%$ of the tree length.

- tests have given a general formula for calculation of the flow forces $\left(\mathrm{F}_{w}\right)$ on anchored trash:

$$
F_{w}=C_{d} \cdot b \cdot(30 \cdot t+1) \cdot \rho \cdot v^{2} / 2
$$

where : $C_{d}=0.006$ for $v<v_{s} ; \rho=$ density of water; $C_{d}=0.08$ for $v_{s}<v<1.1 . v_{s} ; v=$ flow velocity; $C_{d}=0.10$ for $v>1.1 . v_{s} ; v_{s}=$ submerging velocity (of debris tangle); $b=$ width of tangle normal to flow; $1=$ length of tangle in flow direction; $t=$ submerged depth of tangle.

- the flow force will increase significantly when the distance to the crest is less than five times the overflow depth, and that the flow force will be unaffected by upstream depths larger than twice the submerged depth of the tangle;

- wind and waves normally contribute little to the total anchor force unless the flow is very slow or the wind and waves are of extraordinary strength.

Hartung and Knauss (1976) also discuss design considerations for spillways exposed to clogging by woody debris. They make the following suggestions:

- Hydraulic Dimensions: Increase the hydraulic capacity of spillways from the standard $1000 \mathrm{yr}$. design flood to the $5000 \mathrm{yr}$. flood and have a tunnel diameter of $5 \mathrm{~m}$ as a minimum to ensure against clogging;

- Open or closed conduits: Open conduits are unlikely to become seriously clogged. Open type spillways are not always possible, but the authors believe that clogging can be avoided in closed conduits if three conditions are adhered to. These are smooth walls; no contractions or obstructions; no sharp bends; 
- Shape and type of intake structure: The danger of debris build-up obviously decreases with the capacity of a spillway. The intake discharge should be concentrated in one opening and the invert of the intake made as steep as possible to produce a fast exit flow that cannot be resisted by debris jammed at the intake. If the intake has a control gate care must be taken to ensure the design hydraulic capacity through the structure can be met even in the event of the gate becoming blocked; - Gates: The authors recommend that gates should be installed at spillways in order to form a concentrated jet-flow in the centre of the intake. Lift gates should be avoided unless there are a large number of openings because of the danger of trees being drawn below their lower edge during closing. Drum, sector and flap gates should used if possible to avoid this problem.

- Interceptors and skimmers: Floating booms can be effective in keep floating debris away from spillways, but in the case of heavy debris build-up debris may be drawn under the boom. The bank based elements also have to take up the total force of impacting debris and the device must be long enough to remain on the water surface in the event of reservoir draw-down. Fixed, pier-like elements, connected by an access bridge, with a spacing corresponding to the narrowest opening in the spillway may therefore be a more effective, if rather costly, remedy;

- Trash racks: The authors state very strongly that trash racks should never be used at spillway intakes because clogging could potentially compromise the spillway's design flood capacity;

- Stilling basin: Debris passing through spillway can act as high velocity missiles, destroying protruding structural elements such as baffles. It is therefore recommend to use spatial stilling basins which slope upwards at the downstream end where a high debris load could be passed through the spillway;

- Removal of intercepted floating material: The authors suggest dragging material ashore using motor boats. They make the point that the most effective way to prevent debris build-up at reservoirs is to intercept it upstream of the dam using a device such as that described in section 1.2, although such structures are probably cost effective only in the most serious cases;

- Model tests: Physical models are indispensable tools in the design of spillways exposed to large amounts of floating debris. Refer to section 1.6. 


\subsection{Thermal Power Plant Trash Screens}

A reliable debris screening system is essential for the smooth operation of thermal power-plants that are water-cooled. Debris screening at power plant intakes is normally accomplished by a combination of trash bars with raking device followed by an automatic mechanical fines screen. Richards (1988) discusses advances made in screen design which could be used to improve upon the trash rake and "through-flow" type screen that is commonly employed at US power plants (see figures $3.5 \mathrm{a}$ and $3.5 \mathrm{~b}$ ). The paper covers alternative screening configurations including three-unit systems; various types of rotary trash rack for dealing with different volumes and types of debris (such as seaweed and jelly-fish); and mechanical fine screen systems including dual-flow, centreflow, vertical travelling screen, single and double entry screen and outside to inside revolving drum screen types. Richards concludes that the alternative systems, while often proving to be more expensive than the traditional US set-up, generally offer more reliable performance under heavy and variable trash loads and may therefore make better economic sense in the long-run. 


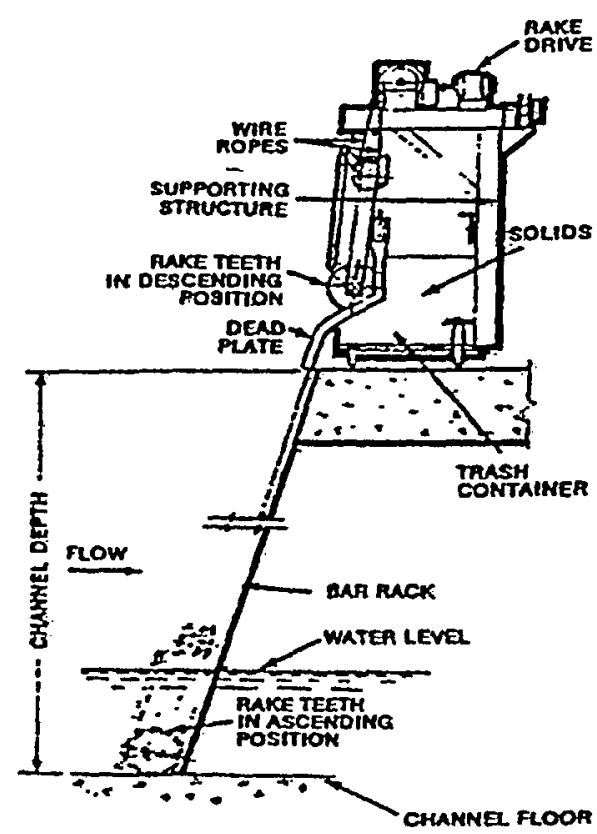

(a)

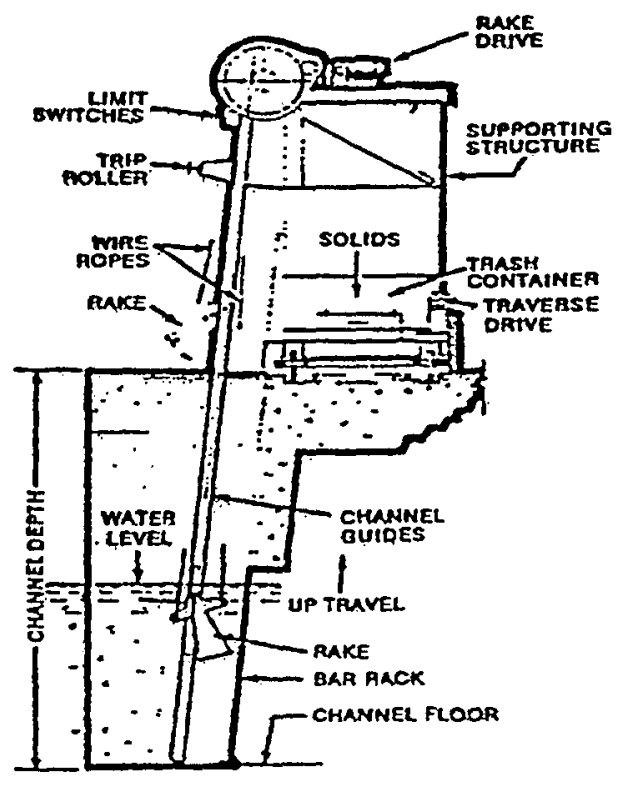

(b)

Figure 3.5a : Trash rakes for thermal power plants (a) unguided and (b) guided (from Richards, 1988) 


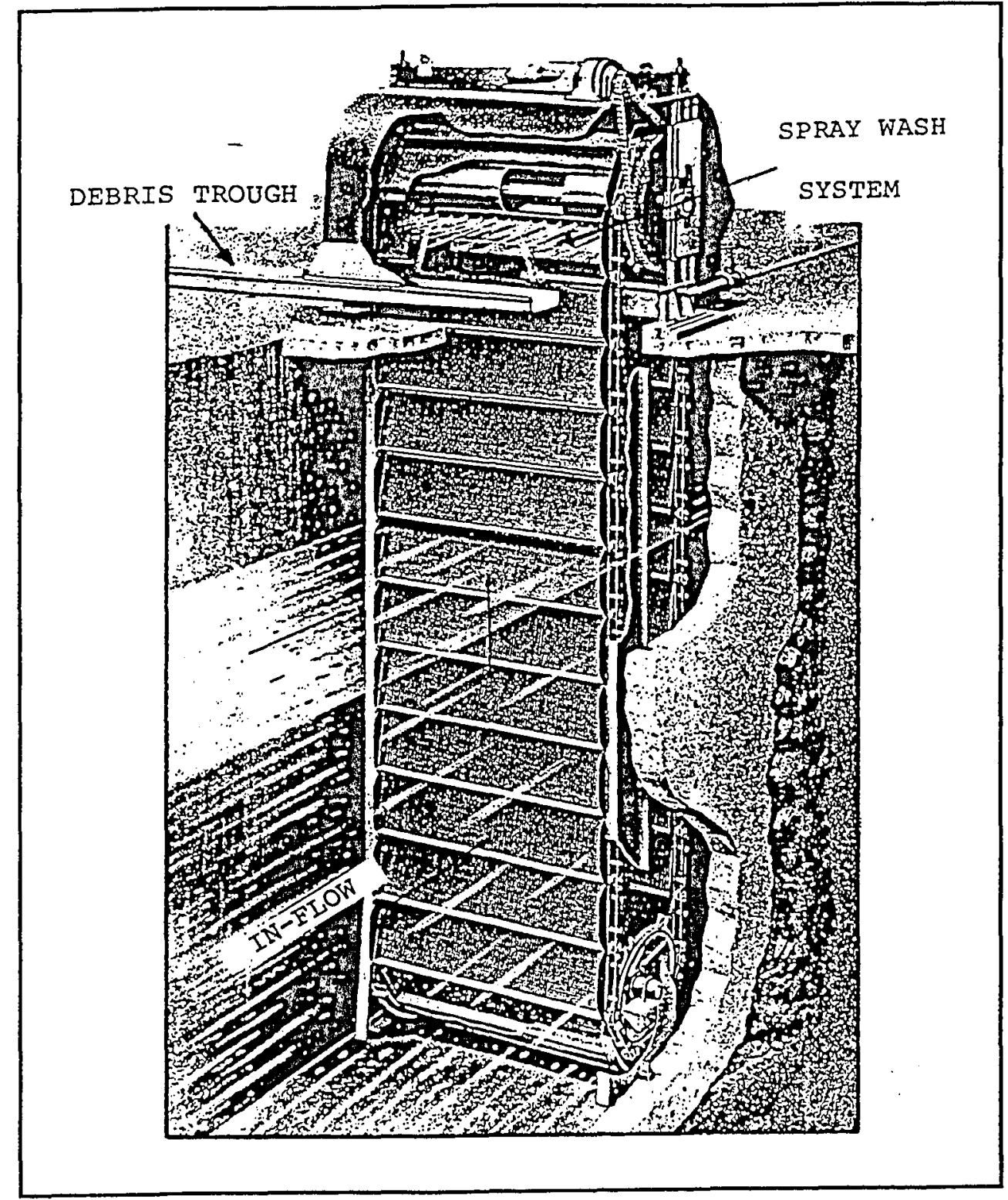

Figure 3.5b : Through-flow travelling screen (from Richards, 1988) 


\section{CONCLUSIONS AND RECOMMENDATIONS}

\subsection{Conclusions}

A summary of best practice design and maintenance procedures for debris management at run of river structures, obtained from interviews, site visits and evaluation of all available literature, is presented here according to each type of structure that has been discussed within the body of this report.

\subsubsection{In-Channel Debris Retention Devices}

These are can be very effective for combating debris transport from high yield source areas to important structures downstream. The "treibholzfang" device that has been utilised in Southern Germany is a very effective means of near-source debris control, if properly maintained, and the use of this technology should be considered where debris transport causes acute problems at in-channel structures in the USA. The downstream pointing "V" device has been shown through model studies to be the most effective design for retaining debris and creating a minimum backwater effect. The only drawback with such devices is their high initial construction cost outlay ( $\$ 1.5$ million) and the fact that they require a maintenance program to remove the collected debris on a regular basis.

\subsubsection{Flow Diversion Tunnels}

If large debris is to be passed through diversion tunnels then it is important that it is aligned parallel to the main flow direction. This may be achieved by using debris aligning piles, as used in the Campo Vallemaggia diversion tunnel, although care must be taken to avoid the possibility of debris straddling piles which could result in a catastrophic debris release into the tunnel during flood conditions. The alternative solution is to create the optimum flow approach conditions and patterns to reduce the potential for clogging the tunnel entrance. To achieve this solution it is worth considering the results obtained by Martin (1989):

- Transition sections from natural channel to entrance channel should be curved to prevent flow separation and eddying;

- The approach configuration shown in figure 2.3a was highly effective in preventing blockage, because the radius allowed for debris to pivot into the tunnel; 
- Configurations shown in figures $2.3 \mathrm{a}$ and $2.3 \mathrm{~b}$ were the most hydraulically efficient for passing debris;

- Blunt edges and flat surfaces at or below the water surface tended to cause turbulence and to gather debris.

There is, however, no substitute for carrying out scale physical model tests when considering new tunnel approaches, using different approach and entrance designs and various, estimates of debris loadings. It is important to remember when carrying out such tests that there are scaling problems between model and prototype as simulated debris is likely to have different roughness, buoyancy and elastic properties to those encountered at full scale.

\subsubsection{Lock and Dam Structures}

Run of River Lock and Dam structures tend to have unique design and operating characteristics which make it difficult to develop a generalised set of recommendations for floating debris management. A customized approach is therefore normally taken at each structure. Procedures common to most structures, however, include the flushing of debris through the lock chamber or over the spillway, the use of booms and mule barges to divert debris to the desired area for conveyance, and the removal of non-essential parts of the structure that might collect debris when flood flows are expected.

The findings of a USACE study (see Martin, 1989) concluded that the amount of debris accumulating around intakes depends on the orientation and location of the locks, and the clearance between the invert and river bottom. Model studies, using simulated debris loads should therefore be considered an essential practice before the construction of new lock and dam facilities in order to obtain optimum flow approach conditions for debris passage or collection.

\subsubsection{Spillways}

Debris can be prevented from passing through spillways by using floating or fixed booms. These are not fail-safe measures, however as some material may get through this first line of defence in stormy conditions or when there are very heavy debris loadings. If debris is to be passed through spillways Brushin et al. (1982) suggest that the following catchment factors should be carefully considered : 
- Catchment hydrological and meteorological conditions;

- Potential for extreme flood events;

- Potential for mobilisation from high yield sediment and debris sources and upstream slope stability in forested areas.

Once potential debris loading have been predicted the engineer should bare in mind the following recommendations (synthesised from Godtland and Tesakar, 1994, and Hartung and Knauss, 1976) to ensure safe debris passage:

- Pillar distance of bridge structures on top of spillway should be at least $80 \%$ of the length of the arriving trees;

- Vertical free opening between the crest and superstructure should be at least $15 \%$ of the tree length;

- Downstream height of sills should not exceed $1 / 3$ of the tree length if a superstructure is present;

- Consider increasing the hydraulic capacity of spillways from the standard $1000 \mathrm{yr}$. flood to $5000 \mathrm{yr}$. flood and have enclosed tunnel diameters of 5 meters minimum;

- Clogging can best be avoided in closed conduits if there are smooth walls, no contractions or obstructions and no sharp bends.

- Intake discharge into spillway tunnels should be concentrated in one opening and the invert made as steep as possible to produce a fast flow that cannot be resisted by debris;

- Care must be taken to ensure that the design hydraulic capacity through the structure can be met even in the event of spillway gates becoming blocked. Drum, sector and flap gates are preferable to lift gates;

- Trashracks should never be used at spillways because clogging could potentially compromise the spillway design flood capacity.

\subsubsection{Power Plant Intakes}

Shallow and deep seated hydro power intakes can be protected from debris by various floating or fixed retaining devices located in the dam upstream the intake structure. Structures that have be used include floating booms, baffle walls, net and, in free flowing rivers, diversion dikes. The cost of such measures will vary with the size of intake to be protected and the potential debris loadings. Boom-type retaining devices are considered to be the first line of defence (Jansen et al., 1988) but 
trash racks are also required at most outlet structures. The following factors should be considered in trashrack design:

- The differential head across the rack and impact forces (see equation 3.4);

- Bar spacing: bars should be spaced so that the clear openings are not greater than the smallest opening in the conduit or turbine. As a rough guideline, for Kaplan turbines the clear spacing between bars should be no more than 1/30 the diameter of the runner, while for Impulse turbines the spacing should not be greater than 1/5 of the jet diameter at maximum needle opening (Zowski, 1960);

- Head loss at the rack (see equations 3.1, 3.2 and 3.3): bars should be as thin as possible for hydraulic efficiency (flat end bars are normally adequate) but not less than $9.5 \mathrm{~mm}$ at shallow intakes and $12 \mathrm{~mm}$ for deeply submerged intakes. Semicircular trashrack seats (in planform) have been found to be the most efficient shape in terms of head loss reduction (Johnson, 1988). Head loss can be reduced at low pressure intake by inclining the trash rack between 15 and 45 degrees from the vertical;

- Vibration response: trashrack vibration can be subdivided into four areas; natural frequency of vertical and horizontal bars (see equation 3.6); excitation frequency; resonance; fatigue. The vonKarmon effect can be alleviated by placing lateral stabilizers made from butyl rubber between bars and bracing;

- Trash rack maintenance and operation: fully submerged racks have less maintenance requirements than semi-submerged racks which must be easy to remove to facilitate repainting. Air bubblers may be necessary to clear racks of ice if the dam is susceptible to freezing. Adverse vortex generation at intakes should be tested for using scale models. The potential for vortex development can be predicted using equation 3.5. Vortex problems can be overcome by using structural measures such as injector shafts (see section 1.7).

\subsubsection{Raking Devices}

Unguided rakes have the advantage of being able to pass over obstructions without becoming jammed and they are also, generally, less costly than guided rakes. However, they are not suited to deep intake structures where bars do not extend above the inlet structure and, if there are strong transverse currents, unguided rakes may become dislodged or overturned. Guided rakes can operate 
on vertical racks, are not affected by transverse currents and can operate on intakes where the trash rack does not extent to the unloading deck. Disadvantages are that the rake guides may become blocked by debris and, under severe debris conditions, may therefore need considerable maintenance work. Because of the operating limitations of mechanical rakes it may be preferable to use more simple types of rake which can be operated by a gantry crane mounted on the dam operating deck. Other debris removal systems available include collection boats, travelling screens (generally for fine debris at thermal power plant intakes), air bubblers and conveyors (refer to Perham, 1987).

\subsubsection{Debris Disposal}

Once collected debris must be disposed of in some fashion. The options available are: burning; burial; if low grade, use as firewood or chipped wood for horticultural purposes; if high grade, use for structural purposes. The latter two options are preferable as they may create some financial return for the operator, while burial is costly and burning is somewhat environmentally unsound, especially if the wood has become contaminated in the river by toxins, hydrocarbons, heavy metals, etc.

\subsection{Recommendations}

Debris build-up is a continual problem at locks, dams, bridges and water intakes and even causes disruption of water based recreation activities. As a consequence debris control systems, which are often site specific, have been developed that incorporate various collection, removal and disposal elements. These systems are, inevitably, costly to construct and maintain. However, order to develop a cost-effective debris control system at a new structure it would be beneficial to have some understanding of the debris dynamics within the relevant catchment area, upstream of that structure. For example McFadden and Stallion (1976) undertook a study for the Alaska District Corps of Engineers to determine the amount, source, and content of debris on the river, and the magnitude of water levels which could cause a substantial debris movement. Also, of particular interest were the average size of the debris pieces and their potential for jamming or damaging the outlet structure of the Chena River Flood Control Dam which was being constructed at the time. These basin-wide studies helped them make more informed recommendations for counteracting log jamming in the dam gates. A system of debris-aligning pilings was advised with the spacing based upon maximum debris dimensions encountered on the river, and a back-up hoist with clam-shell bucket to remove 
logs that might manoeuvre into a jamming position. A cable boom system was rejected on the grounds that it was not as easy to clean as the gates themselves and presented a hazard to navigation. However, the number of projects that use watershed studies in this way are limited, and this is to the detriment of many structures. Martin (1989) concludes that, "while research studies have been undertaken to asses structural alternatives (to debris control) such as booms and "debris" basins (Perham, 1987) further research is needed in debris transport, particularly, quantifying the volume as it relates to distribution and time". In this regard it is recommended that more watershedwide debris related studies are required to build up regional "Debris Budgets", in the same fashion as the calculation of channel sediment budgets. This would involve stream reconnaissance (Thorne, 1993) to identify the location of major debris input zones and the flow/geotechnical input mechanisms, responsible for controlling the volume and timing of debris input; documentation of the composition and average dimensions of the debris load; monitoring and subsequent prediction of the return period of discharge events that can mobilize large quantities of debris; and estimation of debris storage potential, in jams, bars, and in the channel and at any structures upstream of the structure in question. This information can be used to support estimates of the maximum potential volume of debris likely to arrive at the structure in question for a given discharge event. Seasonal estimates of debris yields could then be used to produce an annual "debris hydrograph". In the regions of the US visited by the third author severe debris accumulation problems occasionally occur in reservoirs and in lock and dam operations. However the third author summarized that, "Little interest or incentive was perceived in elevating the state-of-the-art at the district level. Field personnel are open to new suggestions and/or procedures for managing debris, however, there will be resistance to implementation if there is an impact to their limited maintenance resources. It is evident that each district perceives debris management from a different perspective. Debris management received considerable attention in the south-central U. S., particularly where ice is not considered a major concern. However, debris management is a secondary concern compared to ice in the north and eastern U. S." Although the managers of individual structures cannot perhaps see the benefit of or afford measures suggested, run-of-river structures threatened by debris build-up would almost certainly benefit from debris monitoring studies and management strategies that were co-ordinated and funded at the District level. 
Watershed-wide debris studies and the synthesis of the information obtained would assist Districts in developing a predictive capability for floating debris dynamics which, in turn, would allow the development of informed, pre-emptive debris control systems rather simply reacting to debris problems on an ad-hoc, site by site basis. The use of spatial analysis tool such as Geographical Information Systems (GIS) would undoubtedly facilitate the development of watershed debris monitoring and budgeting models.

In small watersheds it may be more cost effective to control debris at source by clearing trash and downed timber from the river floodplain, and through multipurpose channel stabilisation schemes (such as the Demonstration Erosion Control (DEC) project) which would help to reduce excessive debris input into the channel network through bank erosion or channel instability. However, it must be recognised that in-channel Large Woody Debris (LWD) is a beneficial and integral, geomorphological and ecological component of the river system (see Wallerstein \& Thorne, 1994 and 1995). Debris starvation of low order streams could very well have undesirable negative environmental impacts and so the key to debris management must therefore be to moderate the debris budget and control debris output from high yield reaches upstream which feed debris into large rivers containing major structures. This can be achieved by holding debris back at natural debris jams and also by the creation of artificial jams, in the form of retention structures such as that developed and used in southern Germany (see section 1.2). 


\section{REFERENCES}

Abt S. R., Brisbane T. E., Frick D. M. \& McKnight C. A., 1992, "Trash rack blockage in supercritical flow", Journal of Hydraulic Engineering, ASCE, vol. 118, no. 12, pp. 1692-1696

Bisaz E., Taubmann K-C. \& Fischer P., 1976, "Improvement in transport of floating debris", Water Power \& Dam Construction, November

Bruschin J., Bauer S., Delley P. \& Trucco G., 1982, “The overtopping of the Palagnedra dam”, Water Power \& Dam Construction, January

Fripp J. B., Sutton E., Smith L. \& Bhamidipaty S., 1996, "Drift Management at Bluestone Lake", unpublished report, Corps of Engineers, Huntington District, West Virginia

Godtland K. \& Tesaker E., 1994, "Clogging of spillways by trash", 18th congress of ICOLD, Durban, Q68, R36

Grubinger H. \& Vischer D., 1983, “Die Vorgange in einem Geschiebeablagerungsplatz, abstract: The processes in debris detention basins for torrent control", Eidgenossischen Technischen Hochschule, Zurich

Hartung F. \& Knauss J., 1976, “Considerations for spillways exposed to dangerous clogging conditions" 12th congress of ICOLD, Mexico, Q47, R2

ICOLD, 1987, "Spillways for Dams, section 4.5 Protection against floating debris", Bulletin 58, $C I G B$, chapter 4

Jansen R. B., Scherich E. T. \& Regan R. P., 1988, "Advanced dam engineering for design, construction and rehabilitation", Van Nostrand Reinhold, chapter 22

Johnson P. L., 1988, "Hydro-power intake design consideration", Journal of Hydraulic Engineering, ASCE, vol. 114, no. 6, pp. 651-661

Knauss J., 1985, “Von der oberen zur unteren isar”, internal report from the Hydraulics Laboratory of the Technical University of Munich, Obernach, Germany, chapters 2 and 4

Martin S. K., 1989, “Clover Fork Tunnel Diversion Project, Harlan, Kentucky : Hydraulic Model Investigation", Department of the Army, Corps of Engineers, Waterways Experiment Station, Vicksburg, Mississippi, Technical report HL-89-18 
McFadden T. \& Stallion M. (1976), "Debris of the Chena River", US Army Cold Regions Research and Engineering Laboratory, Hanover, NH

Osborn J. F., 1968, "Rectangular-bar trashrack and baffle headloss", Journal of the Power Division, Proceedings of the ASCE, vol. 94, no. PO2, pp. 111-123

Perham R. E. (1987), "Floating debris control: a literature review", Repair, Evaluation, Maintenance and Rehabilitation Research Program, Tech. Report REMR-HY-3, Dept. of the Army, US Army Cold Regions Research and Engineering Lab., New Hampshire, Civil Works Research Unit 32320

Perham R. E. (1988), "Elements of floating debris control systems" Repair, Evaluation, Maintenance and Rehabilitation Research Program, Tech. Report REMR-HY-3, Dept. of the Army, US Army Cold Regions Research and Engineering Lab., New Hampshire, Civil Works Research Unit 32320

Richards R. T., 1988, "Alternative Water Screening for Thermal Power Plants", Journal of Hydraulic Engineering, ASCE, vol. 114, no. 6, pp. 578-597

Sell L. E., 1971, "Hydroelectric Power Plant Trashrack Design", Journal of the Power Division, ASCE, vol. 97, PO1, January

Syamalarao B. C., 1989, "A review of trashrack failures and related investigations", Water \& Dam Construction, January, pp. 28-36

Vischer D. \& Trucco G., 1985, "The remodelling of the spillway of Palagnedra", 15th congress of ICOLD, Lousanne 1985, Q 59, R8

Wallerstein N. \& Thorne C. R., 1994, "Impact of in-channel organic debris on fluvial process and channel morphology, Yazoo Basin, Mississippi", University of Nottingham, Department of Geography, working paper no. 29

Wallerstein N. \& Thorne C. R., 1995, "Impacts of Woody Debris on Fluvial Processes and Channel Morphology in stable and Unstable Streams", US Army Research Development \& standardization Group-UK, London, project no. R\&D 7258-EN-09

Zowski T., 1960, “Trashracks and raking equipment", Water Power, September and October 


\section{References from Syamalarao (1989). See Figure 3.4}

1) von Bugm H. \& Jericha H., 1968, "Fragen der Dimensionterung und Ausbildung der Rechenanlagen vor den Turbineneimlaufen von Flusskraftwerken", Osterreichische Ingemeurzeuschritten, vol. 11, nos. 3 and 4

2) Fortrey J. W. \& Tiry R. F., 1972, "Flow-induced Transverse Vibrations of Trashrack Bars", Civil Engineering, ASCE, May

3) Liess C., 1984, "Wldeck 11 - Auslaufrechen - Ursache der Schwingungsprobleme und Beurteilung des Neuentwurfs", Report No. 14936, JM Voith GmbH, Heidenheim, FRG, April

4) Neilson F. M. \& Pickett E. B., 1979, "Corps of Engineers Experiences with Flow-induced Vibrations", LAHR IUTAM Symposium-Practical Experiences with Flow-induced Vibrations. Eds. E. Naudascher and D. Rockwell, September

5) Schalageter G., 1985, "Erfahrungen am Maschinenhauseinlaufrechen des Rheinkrafts AlbbruckDogern", Wasser, Energie, Luft, vol. 77, no. 10

6) Schol G. A. \& March P. A., 1982, "Model Testing of Trashracks at Hiwassee Dam", Proceedings, ASCE Hydraulics Divisions Conference on Applying Research to Hydraulic Practice. Jackson, Mississippi, Ed. P. E. Smith, August

7) Vanbellingen R., Lejeune A., Marchal J., Poels M. \& Salhoul M., 1982, "Vibration of screen at La Platte Taille Hydro Storage Power Station in Belgium", BHRA Fluid Engineering Conference on Flow-induced Vibrations in Fluid Engineering, Reading, UK, September 


\section{APPENDIX A \\ US CONTACTS}

Mr. Jon Fripp

Hydrology \& Hydraulics Branch

U.S. Army Corps of Engineers

CEORH-ED-HH

502 Eighth Street

Huntington, WV 25701-3070

Mr. L. C. Corken

U.S. Army Corps of Engineers

Monroe Navigation Field Office

3505 South Grand

Monroe, LA 71202-5273

(Office Director)

Mr. Billy Arthur

U.S. Army Corps of Engineers

St. Louis District

ATTN: ED-H

1222 Spruce Street

St. Louis, MO 63103-2833

Mr. Gene P. Allsmiller

Chief, Lock and Dam Section

U.S. Army Corps of Engineers

Loisville District

CEORL-OR-W

P.O. Box 59

Loisville, KY 40201-0059

Mr. Rick Morgan

Chief, Navigation Division

U.S. Army Corps of Engineers

Louisville, $\mathrm{KY}$

CEORL-OR-WN

P.O. Box 59

Louisville, KY 40201-0059

Mr. Jay hawkins

Chief, Navigation Section

U.S. Army Corps of Engineers

2100 Bridgeway Blvd.

Sausalito, CA 94965-1753

Mr. Robert van der Borg

Mechanical Engineer - Operations

U.S. Army Corps of Engineers

Portland, OR
Mr. Ray Shumaker

Columbia L\&D Lockmaster

U.S. Army Corps of Engineers

Monroe Navigation Field Office

3505 South Grand

Monroe, 1A 71202-5273

(Ouachita River)

Mr. Doug Prudnomme

Jonesville L\&D Lockmaster

U.S. Army Corps of Engineers

Monroe Navigation Field Office

3505 South Grand

Monroe, LA 71202-5273

(Black River)

Mr. Fred Pittman

J. H. Overton L\&D Lockmaster

U.S. Army Corps of Engineers

Monroe Navigation Field Office

3505 South Grand

Monroe, LA 71202-5273

(Red River)

Mr. Sutten epps

Planning Division

U.S. Army Corps of Engineers

502 Eighth Street

Huntington, WV 25701-3070

Mr. John H. Azeveda

chief, Operationss Branch

U.S. Army Corps of Engineers

333 Market Street

San Francisco, CA 94105-1905

Mr. Joe McCormick

Inland Master

U.S. Army Corps of Engineers

2100 Bridgeway Blvd.

Sausalito, CA 94965-1753

Mr. Andy Debrize

Structure Crew Foreman

Bonneville Dam 


\section{EUROPEAN CONTACTS}

Prof J. Knauss

Oskar V. Millar Institute,

Technical University of Munich,

Obernach,

Garmisch - Pastenkirchen,

Bavaria,

Germany

Tel : 00498921050

Fax : 00498858788

\section{J. J. van der Zwaard}

Director

Rivers, Navigation and Structures Division,

Delft Hydraulics,

PO Box 152,

Emmeloord,

$8300 \mathrm{AD}$,

The Netherlands

Tel : 3152742922

Fax : 3152743573
Mr A. Chervet,

Head of River Engineering Dept.,

Laboratory of Hydraulics,

Swiss Federal Institute of Tech., Versuchsanstalt fur Wasserbau, Zentrum,

8092 Zurich,

Switzerland

Fax : 004116321192 


\section{APPENDIX B}

\section{BLUESTONE LAKE - DRIFT WORK}

1 January 1982 thru 6 December 1993

\begin{tabular}{|l|l|l|l|}
\hline 1982 & DAYS WORKED & ACRES* & NOTES \\
\hline \hline 7-8 January & 2 & EST 2 & \\
\hline 8-11 February & 4 & EST 6 & \\
\hline 11 March - 7 April & 17 & EST 25 & \\
\hline 15-24 June & 6 & EST 8 & \\
\hline 16 July & 1 & $* *$ & \\
\hline
\end{tabular}

\begin{tabular}{||l|l|l|l|}
\hline 1983 & DAYS WORKED & ACRES* & NOTES \\
\hline \hline 19-24 February & 6 & EST 10 & \\
\hline 13 May - 20 June & 15 & EST 20 & \\
\hline 23 July & 1 & $* *$ & \\
\hline $27-29$ September & 3 & EST 4 & \\
\hline 26 October & 1 & $* *$ & \\
\hline
\end{tabular}

\begin{tabular}{|l|l|l|l|}
\hline 1984 & DAYS WORKED & ACRES* & NOTES \\
\hline 18 February - 2 April & 21 & EST 30 & $\begin{array}{l}\text { Sea Crane installed on barge } \\
\text { 2 March. First used on 5 March } \\
1984 .\end{array}$ \\
\hline 14-17 May & 4 & EST 12 & \\
\hline 5-9 November & 5 & $\begin{array}{l}\text { Lowered pool to 1400.50 } \\
\text { (SF 511). Drift removed from } \\
\text { trash racks 3 feet below surface to } \\
\text { 1397.00. }\end{array}$ \\
\hline
\end{tabular}




\begin{tabular}{||l|l|l|l|}
\hline 1985 & DAYS WORKED & ACRES* & NOTES \\
\hline \hline 28 February - 5 March & 6 & EST 20 & \\
\hline 21 March - & 1 & $* *$ & \\
\hline 23 April & 1 & $* *$ & \\
\hline 20 August & 1 & EST 2 & \\
\hline $17-18$ October & 2 & EST 5 & \\
\hline $11-14$ November & 3 & EST 10 & \\
\hline 27 November & 1 & $* *$ & \\
\hline 17 December & 1 & EST 2 & \\
\hline
\end{tabular}

\begin{tabular}{||l|l|l|l|}
\hline 1986 & DAYS WORKED & ACRES* & NOTES \\
\hline \hline 3-6 January & 2 & EST 4 & \\
\hline 18-20 March & 3 & 5 & \\
\hline 23 June & 1 & EST 2 & \\
\hline 24-29 October & 2 & EST 5 & \\
\hline
\end{tabular}

\begin{tabular}{||l|l|l|l|}
\hline \hline 1987 & DAYS WORKED & ACRES* & NOTES \\
\hline \hline 14 January & 1 & EST 2 & \\
\hline 17 March - 2 April & 9 & EST 35 & \\
\hline 4-7 May & 4, Double Shift & 40 & \\
\hline 21 May & 1 & $* *$ & \\
\hline
\end{tabular}

1988 No reference to drift work in project records. 


\begin{tabular}{||l|l|l|l|}
\hline 1989 & DAYS WORKED & ACRES* & NOTES \\
\hline \hline 23-24 May & 2 & EST 5 & \\
\hline 18-20 July - & 3 & EST 8 & \\
\hline 18-21 September & 3 & EST 8 & \\
\hline 24 September & 0 & 20 & $\begin{array}{l}\text { Drift accumulated after Hurricane } \\
\text { Hugo. Decision made to do test } \\
\text { removal by crane. }\end{array}$ \\
\hline 3 October & 0 & 3 additional & \\
\hline
\end{tabular}

\begin{tabular}{|l|l|l|l|}
\hline 1990 & DAYS WORKED & ACRES* & NOTES \\
\hline \hline 3-7 January & 0 & 14 additional & \\
\hline $6-7$ & 2 & $\begin{array}{l}\text { 1/4 acre removed } \\
\text { (252 tons) }\end{array}$ & $\begin{array}{l}\text { Test removal with } 90 \text { ton } \\
\text { mobile crane. Water } \\
\text { restriction at 30\% due to } \\
\text { compacted drift. }\end{array}$ \\
\hline 12 March - 3 April & 12 & & \\
\hline
\end{tabular}

1991 No drift worked or accumulated.

\begin{tabular}{||l|l|l|l|}
\hline 1992 & DAYS WORKED & ACRES* & NOTES \\
\hline \hline 3-4 February & 2 & 1 & \\
\hline 2-4 March & 3 & 5 & \\
\hline 27 April - 6 May & 8 & 25 & \\
\hline 11-18 June & 6, Double Shift & 32 & \\
\hline
\end{tabular}




\begin{tabular}{|l|l|l|l|}
\hline 1993 & DAYS WORKED & ACRES* & NOTES \\
\hline \hline 5-12 March & & & $\begin{array}{l}\text { 137.5 man hours used to pick trash } \\
\text { from 7 acres of drift. Approx. 15\% } \\
\text { of trash removed amounting to 6 to 7 } \\
\text { pickup loads. }\end{array}$ \\
\hline 16-18 March & 3 & 7 & \\
\hline 13-20 April & 8, Double Shift & 46 & $\begin{array}{l}106.5 \text { man hours used to pick all } \\
\text { trash from 1 acre of drift. Trash } \\
\text { removed 16 vehicle tires, 1 tractor } \\
\text { tire and approx. 13 cu. yds. } \\
\text { (1.03 ton) of other trash. }\end{array}$ \\
\hline $\begin{array}{l}\text { 5-6 December } \\
\text { Drift accumulated }\end{array}$ & Not passed & 1 & \\
\hline
\end{tabular}

\begin{tabular}{|l|l|l|l|}
\hline 1994 & DAYS WORKED & ACRES* & NOTES \\
\hline \hline 29-31 January & Not Passed & 1 & \\
\hline 12-13 February & Not Passed & 3 & $\begin{array}{l}\text { 169 man hours used to pick trash from } \\
\text { acres of drift. Trash removed: } \\
21 \text { vehicle tires, 2 propane tanks and } \\
\text { approx. 16 cu. yds. (1.92 ton) of other } \\
\text { trash. }\end{array}$ \\
\hline 15-16 March & & $\begin{array}{l}\text { Drift Exercise and Flow Study with } \\
\text { Painted Drift }\end{array}$ \\
\hline 30-31 March & Not Passed & 5 & \\
\hline $\begin{array}{l}\text { 8-31 August } \\
\text { 18-19 August }\end{array}$ & & $11 / 2$ & Removed during contract. \\
\hline $\begin{array}{l}* \text { Reference to acres of drift is after a few days compaction has occurred. Acreages were } \\
\text { calculated unless EST is indicated. Any acreage listed as EST is based on project personnel } \\
\text { knowledge of time required for drift removal. } \\
\text { ** Most references to 1 day of work are likely cleanup of additional material which floated } \\
\text { from the bank after initial removal. }\end{array}$ \\
\hline
\end{tabular}




\begin{tabular}{|l|l|l|l|}
\hline 1995 & DAYS WORKED & ACRES* & NOTES \\
\hline \hline 15-17 January & & 32 & \\
\hline 18-20 January & & & $\begin{array}{l}\text { 143 man hours used on barge and jon } \\
\text { boat to remove approx. 1 ton of bagged } \\
\text { material; 24 tires, 4 barrels \& 2 vehicle } \\
\text { gas tanks. Corps and contract } \\
\text { personnel used. Cannot tell where } \\
\text { trash was removed. }\end{array}$ \\
\hline $\begin{array}{l}\text { * Reference to acres of drift is after a few days compaction has occurred. Acreages were } \\
\text { calculated unless EST is indicated. Any acreage listed as EST is based on project personnel } \\
\text { knowledge of time required for drift removal. } \\
\text { ** Most references to 1 day of work are likely cleanup of additional material which floated } \\
\text { from the bank after initial removal. }\end{array}$ \\
\hline
\end{tabular}




\section{APPENDIX C}

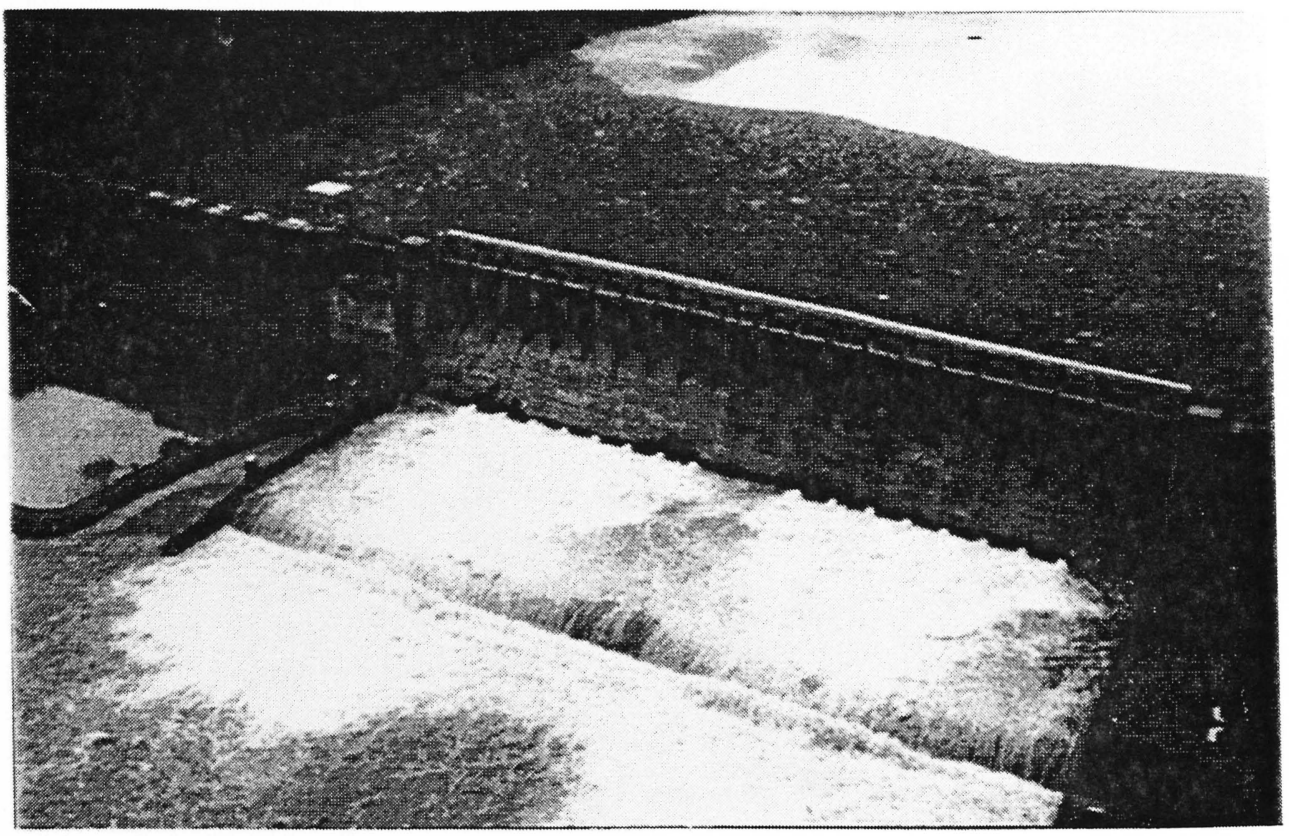

Bluestone Dam, March 1993, Flood Event

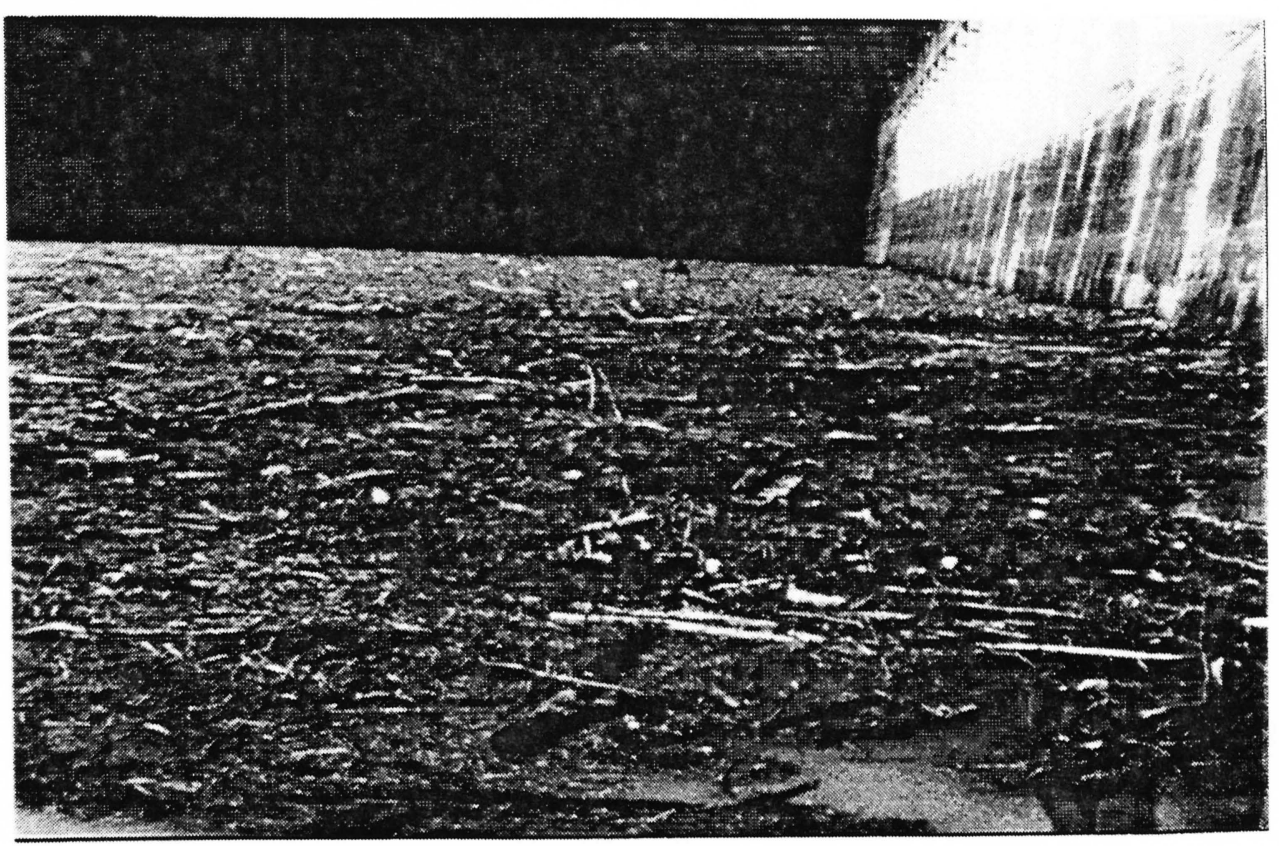

Bluestone Dam, January 1995, Flood Event 


\section{APPENDIX D}

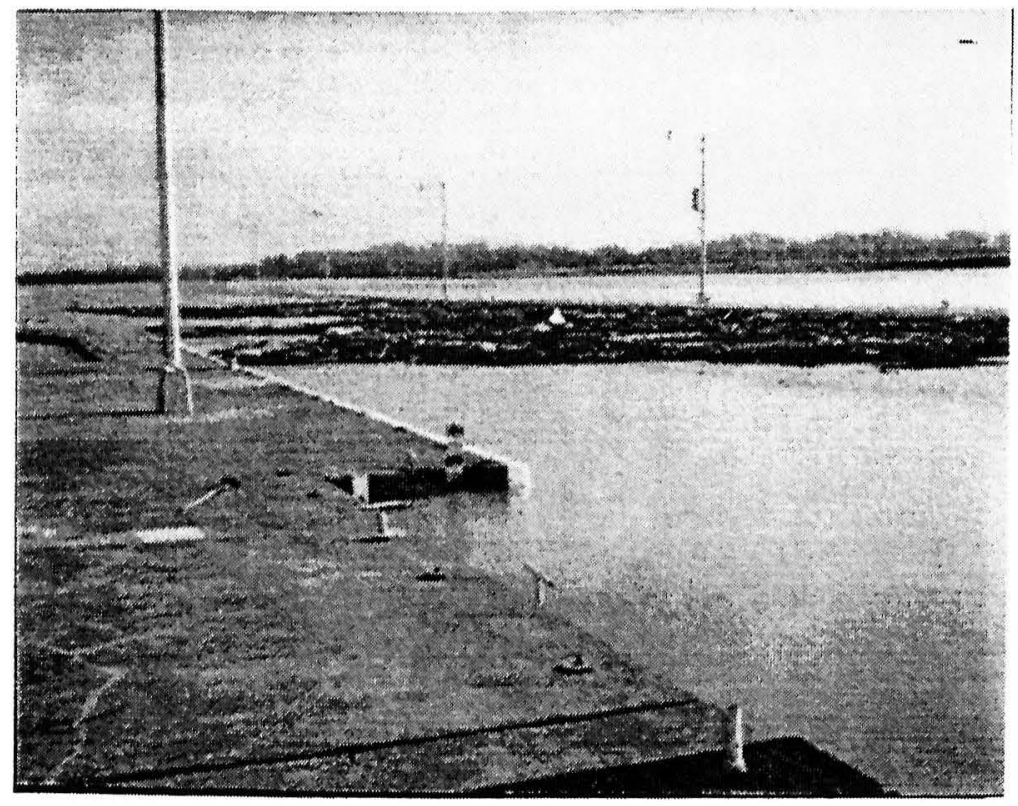

Black River, March 1995

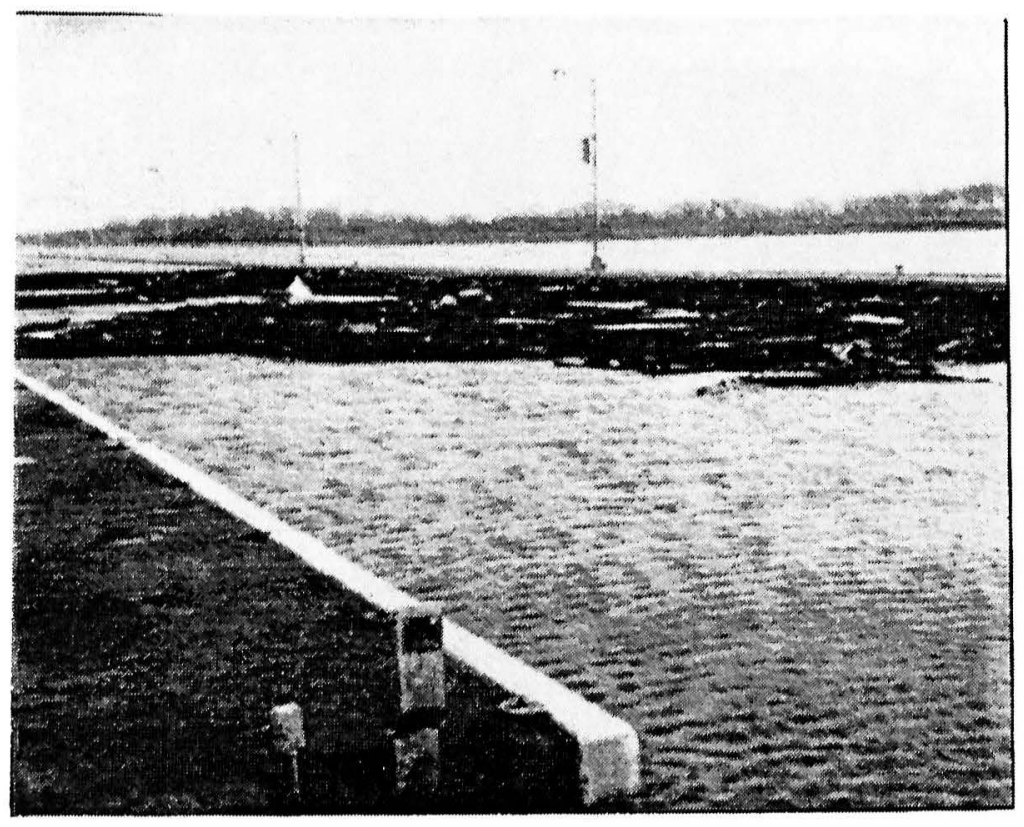

Black River, March 1995 


\section{APPENDIX E}

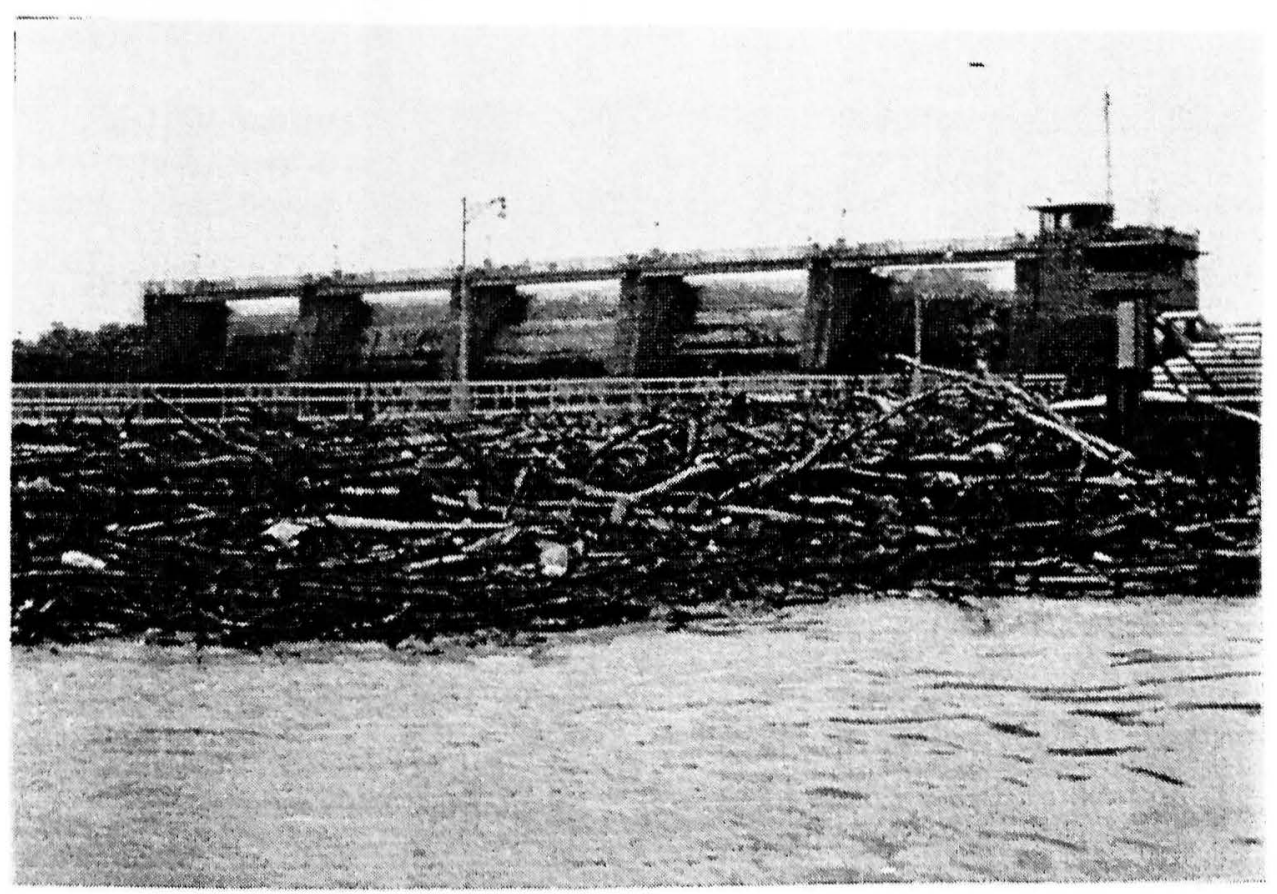

Typical log jam, Lock and Dam Operation

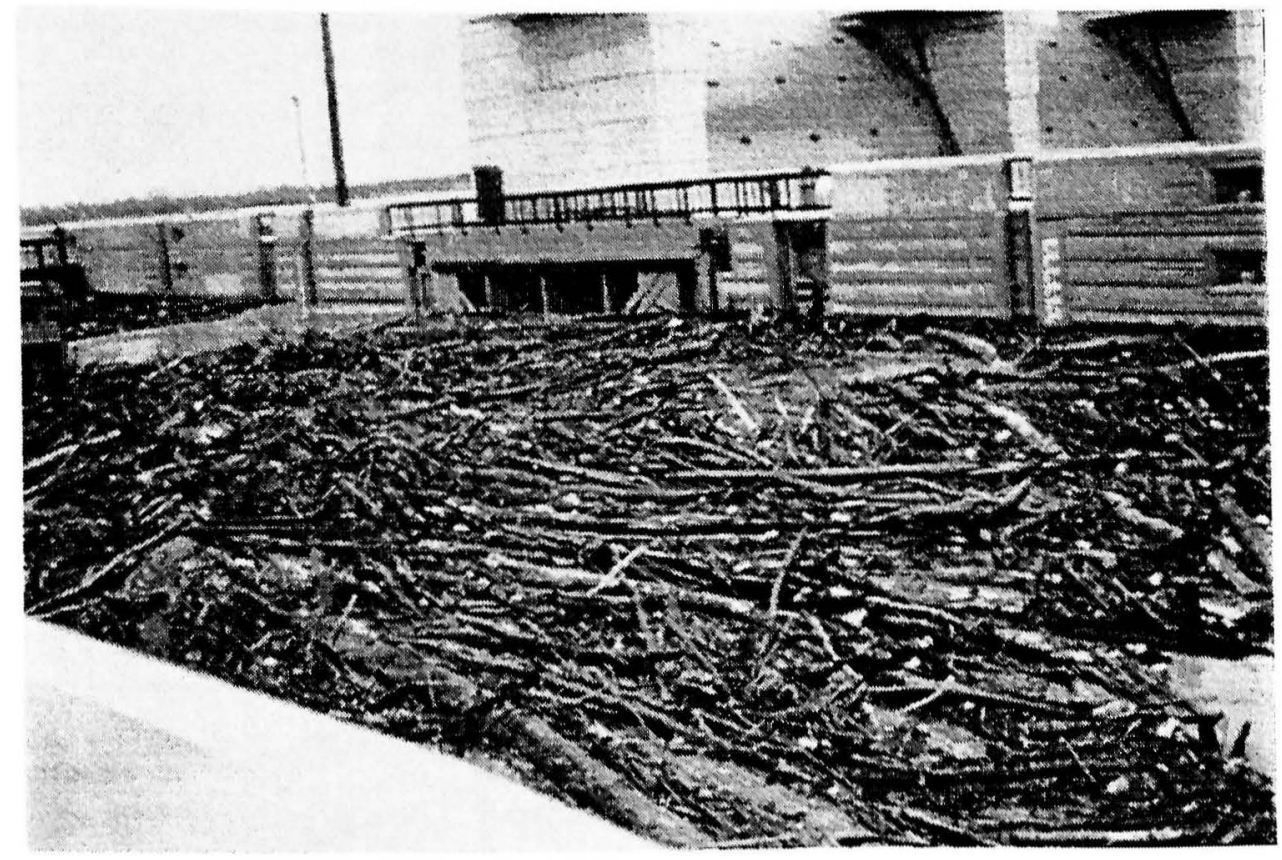

Typical log jam, Lock and Dam Operation 


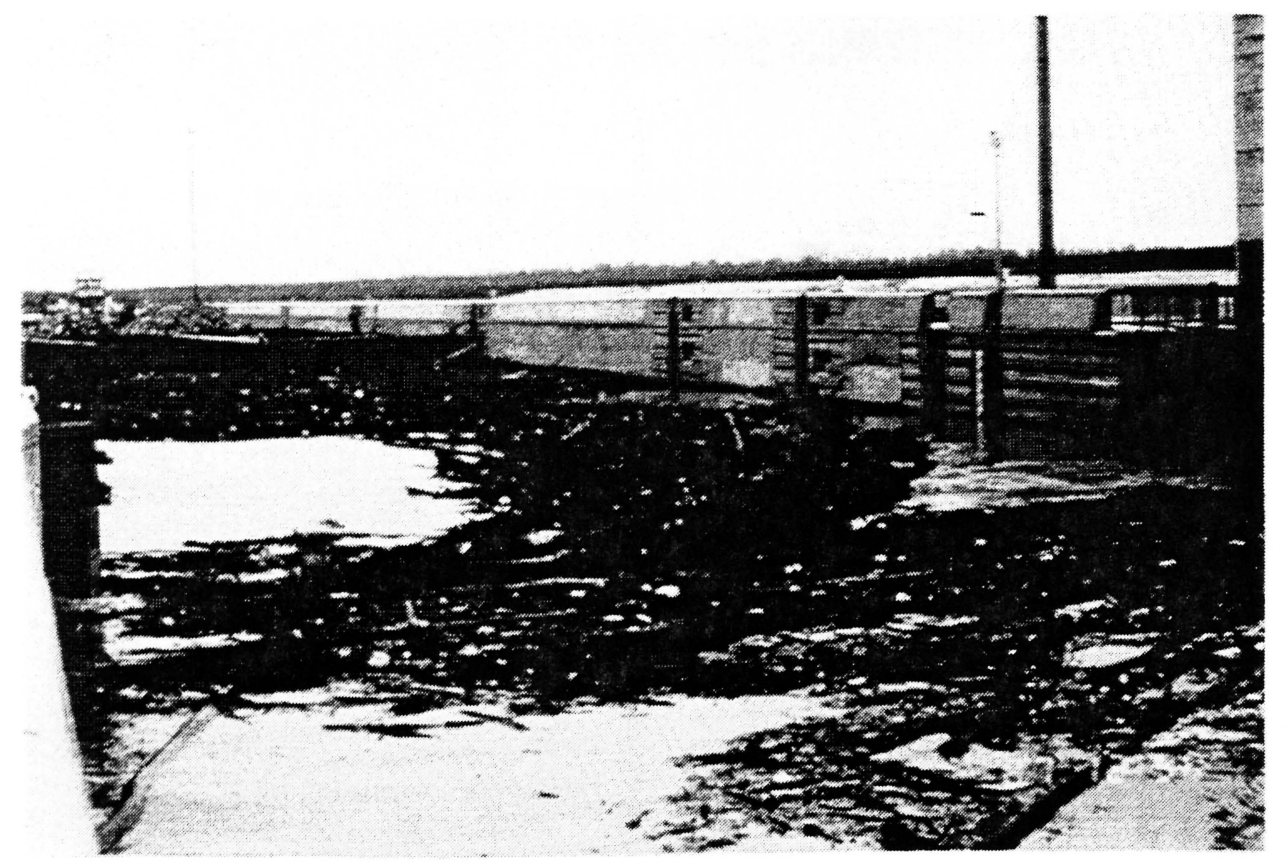

Typical log jam, Lock and Dam Operation

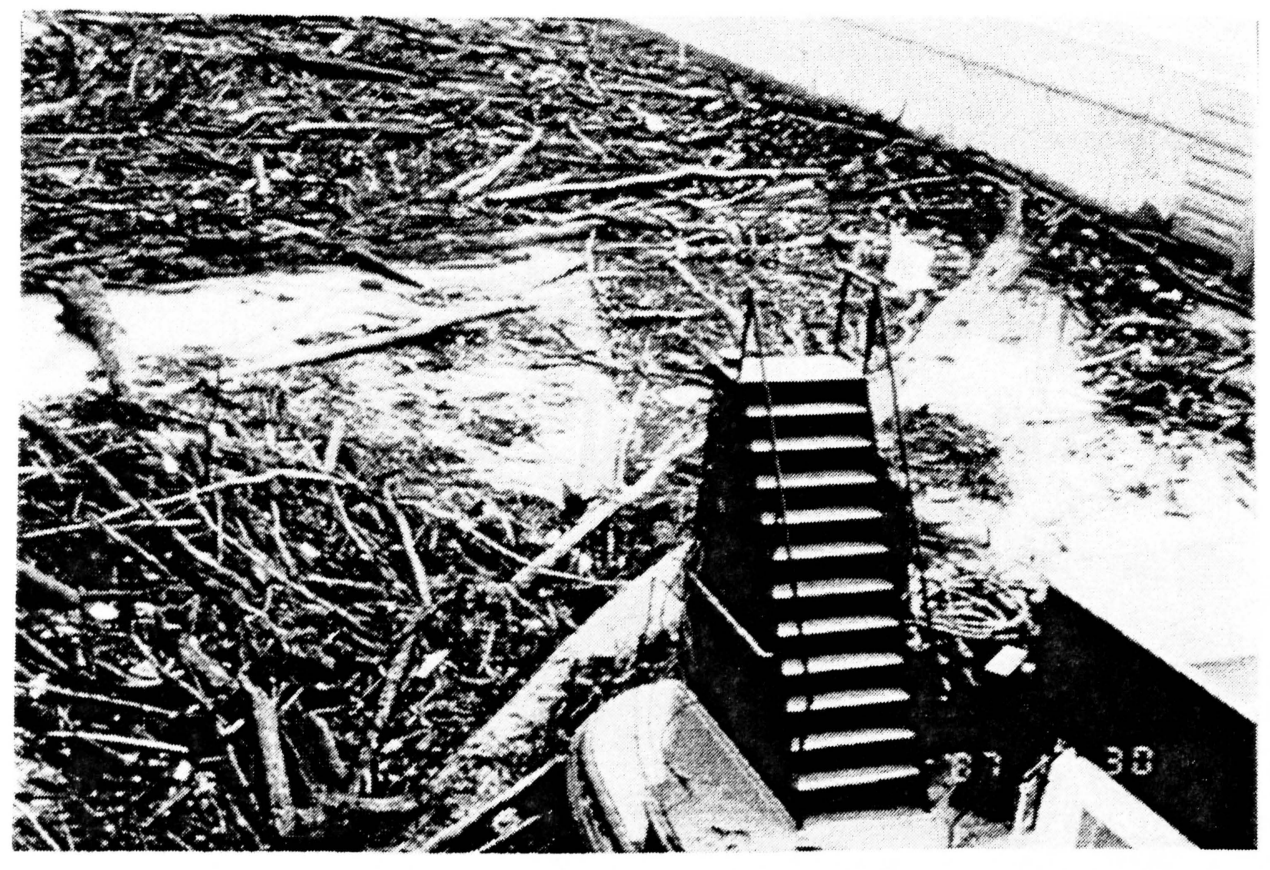

Typical log jam, Lock and Dam Operation 


\section{APPENDIX F}

\section{BENEFITS}

The 1200-foot long lock chamber of the Markland Locks enables tows to pass in one operation instead of having to break up and lock through in smaller sections.

The Markland Locks and Dam has replaced five outmoded locks and dams with one modern structure, thus reducing travel time because only one lockage is required instead of five.

Faster lockage through the new structure due to floating mooring bitts and eight-minute filling or emptying of the lock chambers.

Reduction of annual operation and maintenance costs because one lock and dam replaced five existing structures.

Reduction of annual channel maintenance dredging formerly required in the old low lift pools.

The deeper, wider and more stable pool formed by the Markland Locks and Dam permits more efficient operation of towboats and enhances the efficiency of terminal operations in the area.

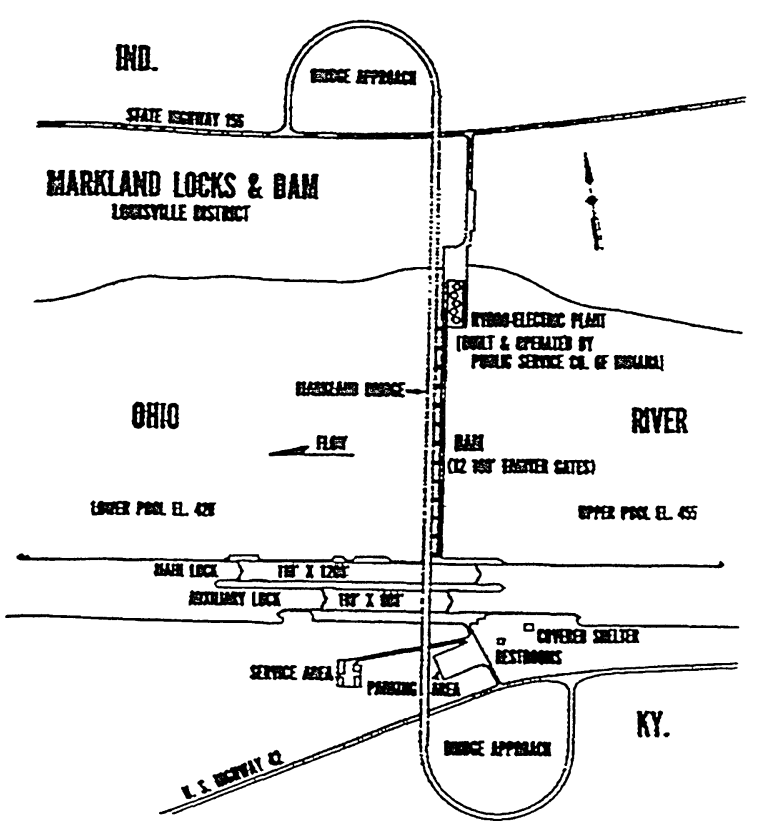

\section{Markland Locks \& Dam}
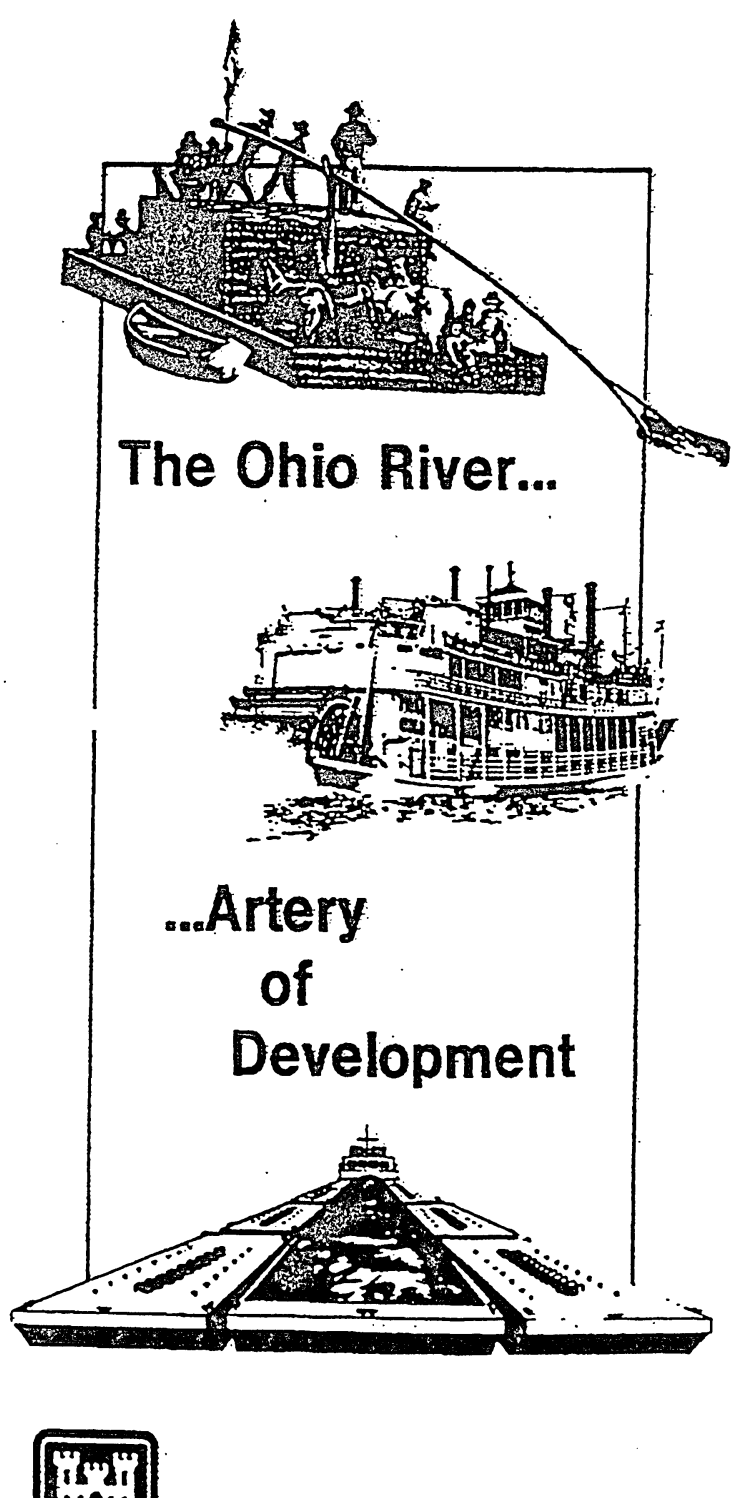

focis

US Army Corps

of Engineers

Louisville District 


\section{LOCATION}

The Markland Locks and Dam is located on the Ohio River at mile 531.5 below Pittsburgh, Pennsylvania. It is $26-1 / 2$ miles upstream from Madison, Indiana and 3-1/2 miles downstream from Warsaw, Kentucky. The navigation locks are located on the left bank or Kentucky side of the river. The upper pool above the dam extends upstream for a distance of 95.3 miles to the Meldahl Locks and Dam at mile 436.0 and for a short distance up three navigable tributaries the Miami, Licking, and Little Miami Rivers.

\section{STATISTICAL INFORMATION}

\section{DAM}

Type $\ldots \ldots \ldots \ldots \ldots \ldots \ldots$. Tainter gate Length ................... 1,395 feet Upper pool elevation

(above sea level) ............. 455.0 feet

Lower pool elevation

(above sea level) ..............4 420.0 feet

Number of gates $\ldots \ldots \ldots \ldots \ldots \ldots \ldots \ldots . \ldots \ldots$

Height of gates ................. 42 feet

Width of gates .................. 100 feet

Clearance of gates above

maximum high water when

fully raised 5 feet

\section{LOCKS}

Number $\ldots \ldots \ldots \ldots \ldots \ldots \ldots \ldots \ldots \ldots 2$

Location ................. Along left bank

Lift ......................... 35 feet

Size of main lock

chamber (in feet) . . . . . . . . . . . $110 \times 1,200$

Size of auxiliary lock

chamber (in feet) ............... $110 \times 600$

WATER SAFETY ....

\section{THE DIFFERENCE BETWEEN}

\section{HYDROELECTRIC POWER PLANT}

Under license granted by the Federal Power Commission, the Public Service Company of Indiana constructed and operates a run of river hydroelectric power plant at Markland Dam. Capacity of the plant is $81,000 \mathrm{kva}$. Operation of the plant is fully compatible with other purposes of the Markland project.

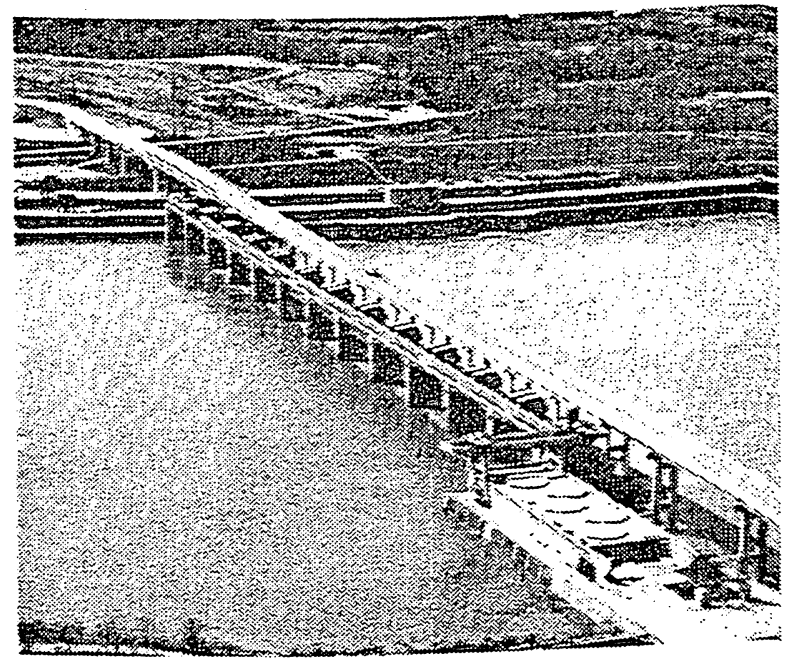
AUTHORITY

The replacement plan for Ohio River Locks and Dam No. 35, 36, 36, 38, and 39 by the Markland Locks and Dam was reviewed by the Board of Engineers for Rivers and Harbors and was approved by the Secretary of the Army on 11 March 1953, all in accordance with the River \& Harbor Act approved 3 March 1909.

Construction of the Markland Locks commenced in March 1956 and was completed in April 1959 at which time construction of the new modern high lift dam began. As work progressed on the dam, the old outmoded upstream Locks and Dam 35, 36, 37, 38, and 39 were demolished and the pool progressively raised until maximum pool stage was reached. The dam was finished in the summer of 1963 and the entire facility was placed in operation at this time.

\section{LIFE AND DEATH!!!}




\section{APPENDIX G}

CEORL-ED-HD

AUGUST 1995

\section{MEMORANDUM FOR RECORD}

\section{SUBJECT: DEBRIS ACCUMULATION AT OHIO RIVER LOCK INTAKES}

The undersigned conducted a study to estimate the quantity of debris accumulation at the culvert intake manifolds at Ohio River Locks. Past dive reports were collected in order to determine the quantity of debris accumulating around the intakes as well as the problems it causes. Also, there was correspondence with the Lock Masters at the facilities investigated to get a feel for the problems they have had with debris. The Ohio River studies include: Markland L\&D, McAlpine L\&D, Cannelton L\&D, Newburgh L\&D, and Uniontown L\&D. The following is a summary of the findings.

\section{MCALPINE LOCKS AND DAM}

McAlpine Locks and Dam are located on the Ohio River near Louisville, Kentucky, 606.8 miles below Pittsburgh, Pennsylvania. The locks are located in a bypass canal on the left overbank forming Shippingport Island on the riverward side. The structures, designed to maintain a minimum upper pool during low flows extending about 75 miles upstream to Markland Locks and Dam, include a 1,200-ft lock located a the lower end of a 1.75-mile-long canal along the left bank, one auxiliary lock between the main lock and left bank that is out of service, and on 600-ft auxiliary lock landward that is used during emergencies.

For this study, only the intakes for the operational 1200-ft lock were examined. There are six intake openings in the South Wall (Middle Wall) and eight intake opening in the North Wall (River Wall). Each intake opening is covered by screens made of $2^{\prime \prime} \times 1 / 2^{\prime \prime}$ vertical bars.

The only records of past dive inspections of intakes were provided by Tom Berry, McAlpine Lockmaster. These included reports form 27 August 1981, 18 November 1982, 13 June 1986, and 15 July 1993.

Both the North and South Wall intakes were inspected on the $25^{\text {th }} \& 26^{\text {th }}$ of August, 1981. The divers reported that the screens on the north wall were in good condition, however, they reported that drift was a problem and was about $1 / 4$ of the way up from the bottom on most openings. The intakes on the north wall are located in a pit about $18^{\prime}$ deep below bedrock. This is an unusual configuration required because of the geology of the Falls of the Ohio. Therefore, there was approximately $110 \mathrm{CY}$ of debris accumulated in the pit. As for the south wall intakes, 3 of the 6 openings were in good condition and the others had bent and worn screens. This manifold is also in a pit about 14' below bedrock. The divers suggested that these openings be reworked. 
The intakes on both walls were inspected again in November of 1982. All intake screens were in the same condition as the previous year. However, it was reported that the drift was now about half the way up from the bottom on most openings on the north wall. Therefore, there was approximately $190 \mathrm{CY}$ of debris in the pit.

The intake openings were inspected in June of 1986 and most of the screens on the south wall needed reworking. On the north wall there were several large logs/trees stuck in the openings and most of the screens were in need of reworking.

The last inspection was completed in July of 1993. All of the screens on both walls were in poor condition with most of the openings $1 / 2$ full of debris and a few openings completely full of debris.

Although the dive reports show that there is some drift entering the intake openings, the amount is minimized because of the location of the locks in the canal. It is expected that much of the drift and debris bypasses the canal and is carried downstream. Also, mud flats have formed on the Kentucky shore at the entrance to the canal, showing a tendency for sediment to drop out before it reaches the lock. As can be seen in Figures A and B these mud flats are catching some of the debris as it comes downstream before it enters the canal.

\section{CANNELTON LOCKS AND DAM}

Cannelton Locks and Dam are located on the Ohio River approximately 720.7 river miles below Pittsburgh, Pennsylvania, and about 3 river miles upstream from Cannelton, Indiana. The structures, designed to maintain a minimum upper pool during low flows extending upstream about 114 river miles to McAlpine L\&D, consist of one 1200 -ft main lock chamber and $600-\mathrm{ft}$ auxiliary lock located on the left bank (Indiana side) of the river. There are eight intake opening per each of the three lock walls.

Several dive reports between 1982 and 1993 were provided by Jay Davis, Cannelton Lock Master. The findings from each dive inspection were consistent from year to year. The land wall and middle wall intakes stayed approximately a third to a half filled with large logs sticking out of most of the openings. The screens were in bad shape in all of the inspection reports. However, not much drift was found on the river wall. There is approximately 17' of clearance between the bottom of the intakes on the river wall and the river bottom allowing debris to drop to the river bottom when the lock is not filling.

\section{MARKLAND LOCKS AND DAM}

The Markland Locks and Dam is located on the Ohio River at mile 531.5 below Pittsburgh, Pennsylvania. The navigation locks are located on the left bank (Kentucky side) of the river. The lock structures include one 1200-ft lock chamber and one 600-ft lock chamber. There are eight intake openings per each of the three lock walls. 
On July 20, 1995 a site visit was made to Markland L\&D to observe the dewatered 600-ft lock chamber. A significant amount of debris was present in the chamber. An excessive amount of debris has been a trend at Markland L\&D. The lock chamber is flushed prior to dewatering, therefore some of the debris was washed out, still leaving an excessive amount. See Figures $C$ and D. Although not all of this debris entered the chamber through the intake openings, it does demonstrate the amount of debris that can be expected at Markland in the future.

In October of 1993 the screens on the intake openings on the Middle Wall were replaced with newly designed removable intake screens. The new design consists of one large screen that covers all of the intake openings. It can be interchanged to allow repairs to be made on land. On August 7, 1995 a dive inspection was performed to monitor the performance of these new intake screens. Since the screens were installed in 1993, approximately 10' of drift has accumulated across the intake openings.

\section{NEWBURGH LOCKS AND DAM}

The Newburgh Locks and Dam is located on the Ohio River near Newburgh, Indiana, at mile 776.1 below Pittsburgh, Pennsylvania. The navigation locks are located on the right bank (Indiana side) of the river. The upper pool maintained above the dam extends upstream for a distance of 55.4 miles to the Cannelton Locks and Dam. The lock structures consist of one 1200-ft lock and one 600 -ft lock. There are eight intakes per each of the three lock walls.

Dive inspection reports concerning the intakes could not be located for Newburgh locks. According to Bob Vanwinkle, Lockmaster at Newburgh L\&D, the intake screens on the landwall and middle wall were replaced in 1991. In order to change the screens they had to clam out about 4' of debris and sedimentation to get to the openings. Although debris is partially blocking the openings on the intakes, Mr. Vanwinkle noted that there was not noticeable problem with the filling time of the locks.

\section{UNIONTOWN}

The Uniontown Locks and Dam is located on the Ohio River about 3-1/2 miles downstream from Uniontown, Kentucky, at mile 846.0 below Pittsburgh, Pennsylvania. The navigation locks are located on the right bank or Indiana side of the river. The upper pool maintained above the dam extends upstream 68.3 miles to the Newburgh Locks and Dam. There are eight intakes per each of the three lock walls. On the middle wall, 4 intakes are located on the $1200-\mathrm{ft}$ side of the wall and the other 4 on the $600-\mathrm{ft}$ side of the wall.

According to Gary Daws, Lockmaster at Uniontown L\&D, Uniontown does not get as much debris as other locks because of the bends in the river upstream of the locks. Much of the debris coming downstream builds up in these bends in the river, therefore never reaching the locks. Also, there is no noticeable problems with filling time. 
A dive inspection was performed on the intake screens on the land, middle, and river wall in August of 1994. Several screen bars needed replacing on all of the intakes. On the land wall, it was noted int eh dive report that it would be necessary to clam shell around the intakes to remove heavy drift and mud in bottom quarter of the intakes. There was some mud and drift in the middle wall intake openings, but the divers had about 4' of clearance from the bottom and did not need these intakes clammed out. The river wall intakes were in similar condition to the middle wall intakes with some clearance below the intakes. They did not require any digging out to replace screens.

\section{CONCLUSIONS}

The amount of debris accumulation around intakes can depend on the orientation and location of the locks as well as the amount of clearance between the inverts and the river bottom. Table 1 shows the invert elevations and river bottom elevations for the locks investigated in this study.

Cannelton Locks and Markland Locks tend to have a significant amount debris because of the location of the locks in the outside of mild bends in the river. These locks were designed to allow barge traffic to have easy access to the lock chamber by allowing them to stay on their flow path. Unfortunately, this also allows drift and debris floating downstream to enter the lock approach.

In the past, Uniontown, Newburgh and McAlpine have not had a significant problem with debris. There are two significant bends in the river just upstream of Uniontown L\&D at which some of the drift being carried downstream accumulates near the bank, never reaching the locks. Newburgh L\&D does not have a straight approach for the barges, therefore the debris does not either. And as discussed earlier, McAlpine Locks are located at the end of a long canal. Much of the debris bypasses the canal and is carried downstream.

In the past, there has been no scheduled maintenance on the intakes, as far as removing debris from around them. The trend has been that only on occasion when the screens need repairing and the divers cannot get to them are the intakes clammed out. However, the acting Lockmaster at Markland L\&D has requested that the intakes be clammed out every two years. This may be necessary at Markland and Cannelton, but the other locks would probably require less. From the findings of this research, possibly every five years would suffice.

Based on rough estimates, the proposed McAlpine Lock intake can expect to attract about half of the $160 \mathrm{CY}$ of material now accumulating at the intakes of the existing 1200-ft lock every year. Any under-the-sill intake design at Markland or Cannelton could be expected to attract about $200 \mathrm{CY}$ per year. The trough to be provided for debris accumulation at McAlpine would hold about $345 \mathrm{CY}$ below the invert of the intake.

Jane E. Howell

Civil Engineer 


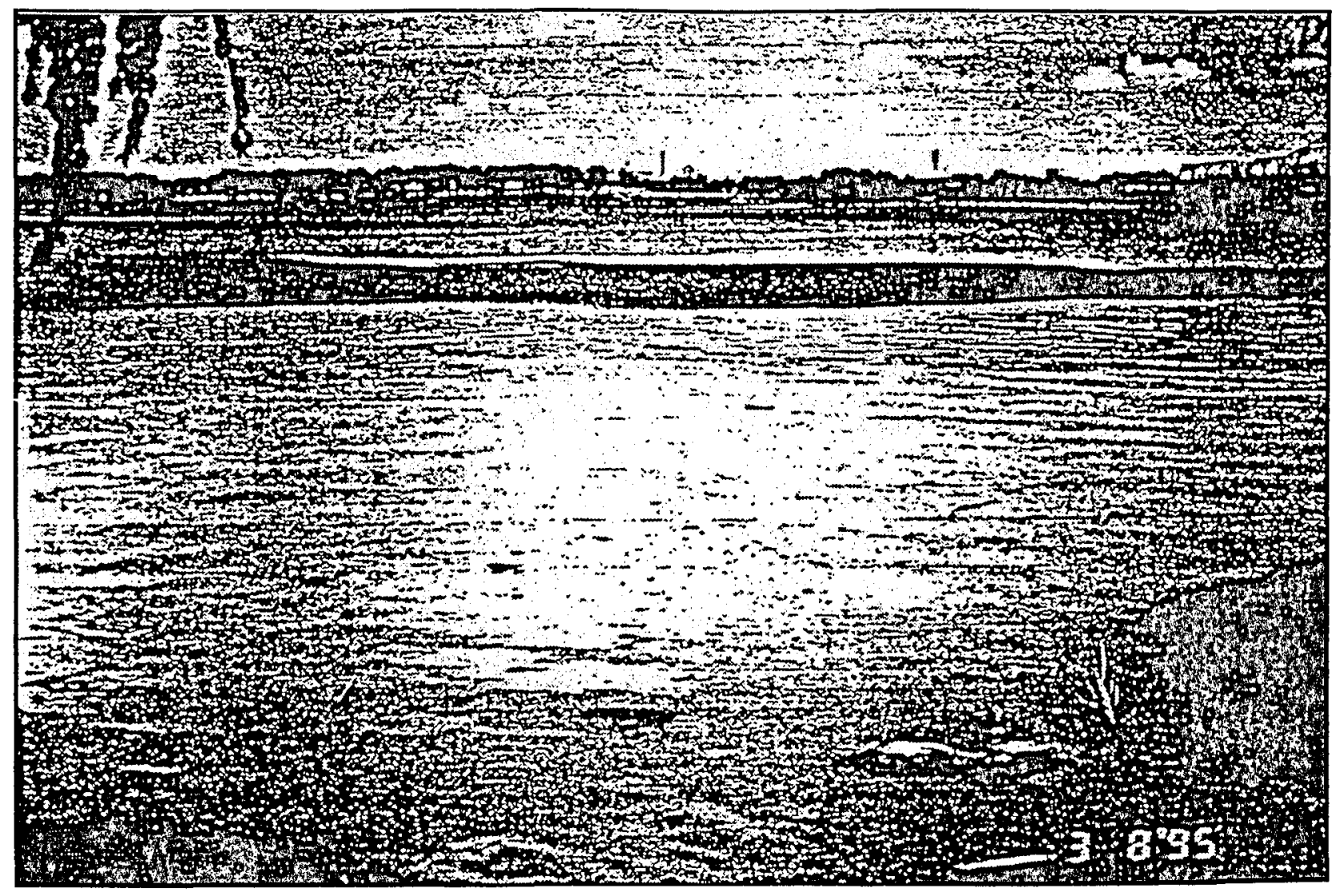

FIGURE A - MUD FLATS UPSTREAM OF MCALPINE L\&D (looking toward Indiana shore) 


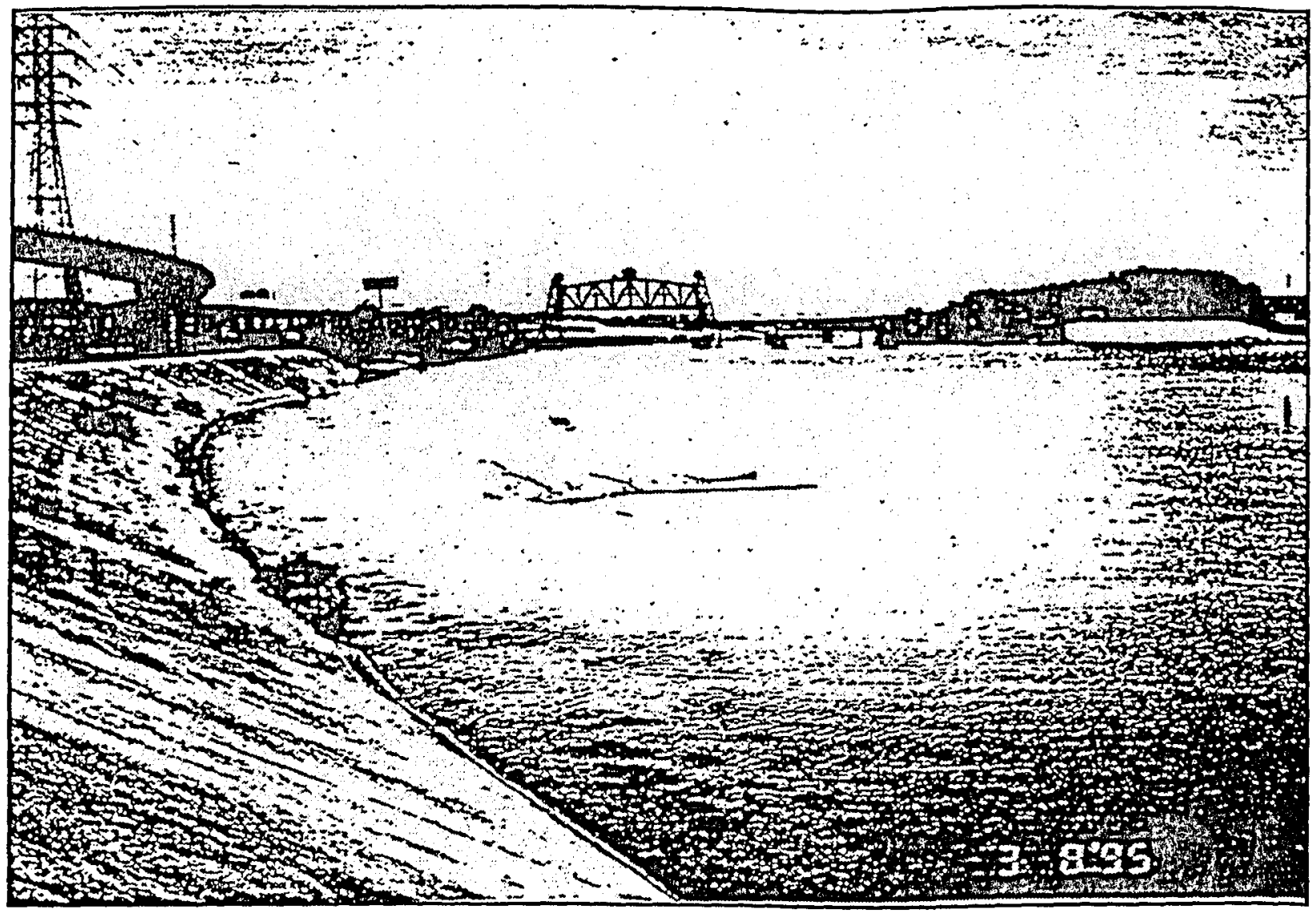

FIGURE B - MUD FLAT UPSTREAM OF MCALPINE WITH DEBRIS ACCUMULATION (looking downstream toward canal) 


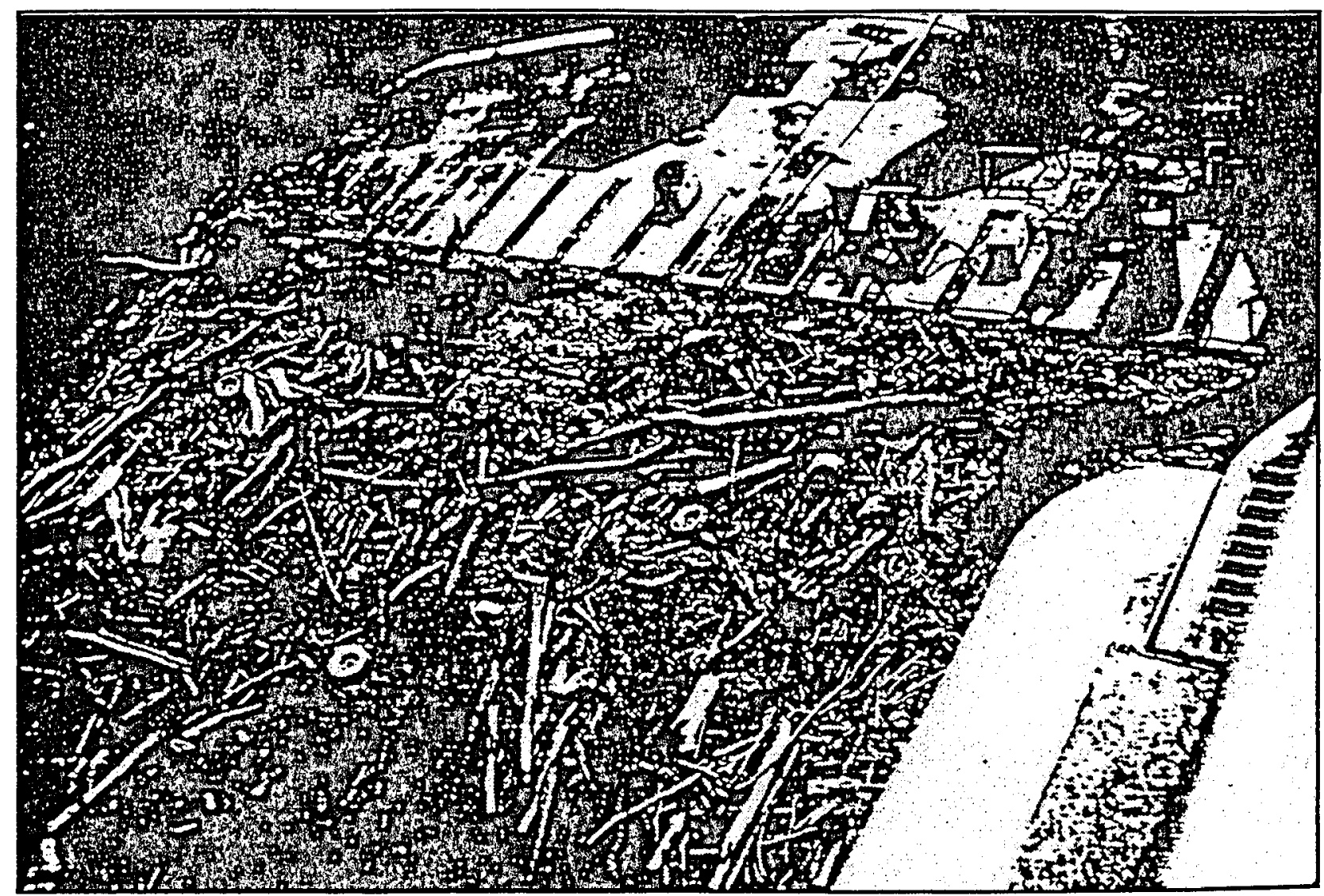

FIGURE C - DEBRIS ACCUMULATION - MARKLAND 600-FT LOCK CHAMBER (looking down into the lock) 


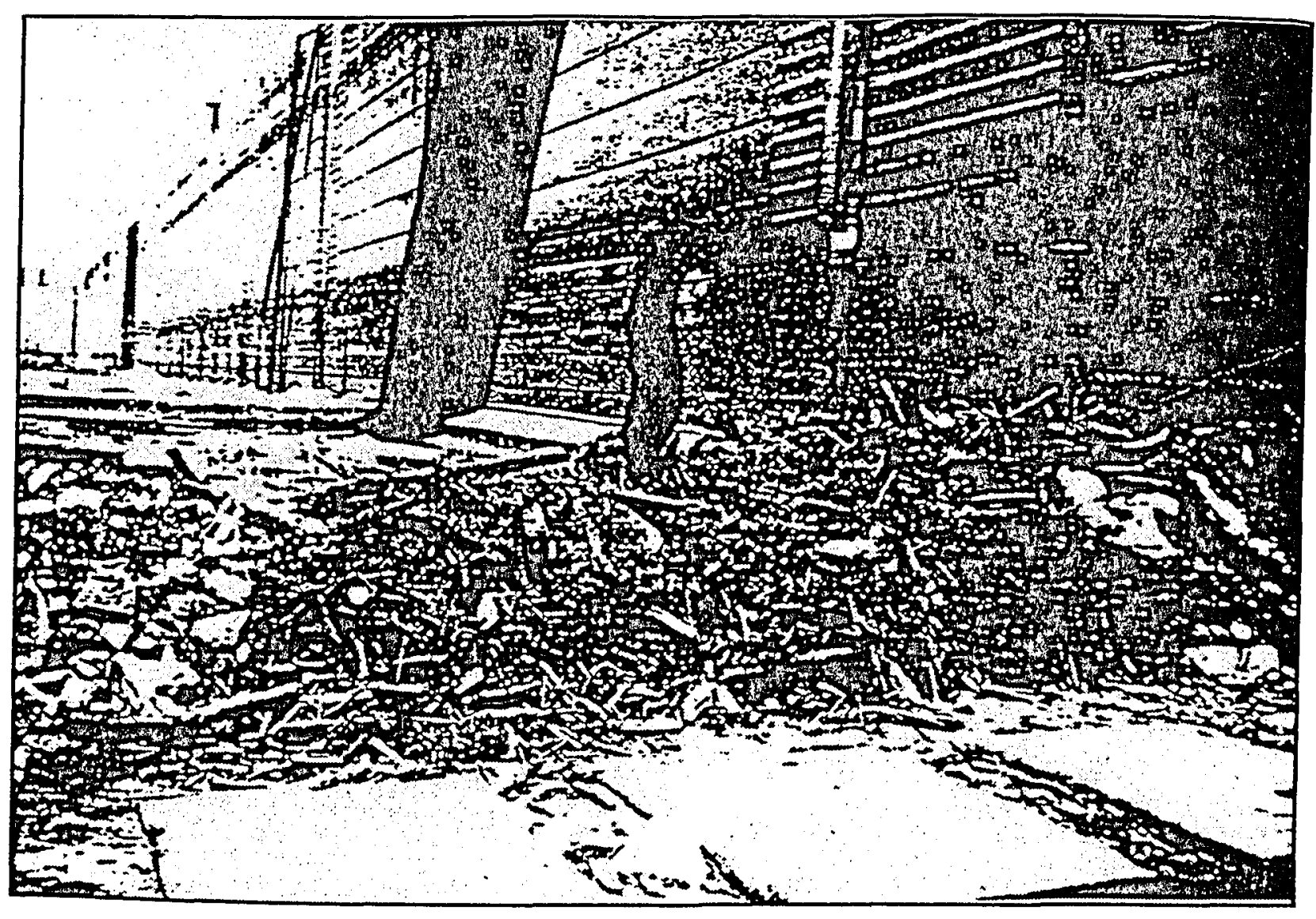

\footnotetext{
FIGURE D - DEBRIS ACCUMULATION - MARKLAND 600-FT LOCK CHAMBER (view from down in the lock chamber)
} 


\begin{tabular}{|c|c|c|c|c|c|c|c|c|}
\hline \multicolumn{9}{|c|}{ CANNELTON LOCKS AND DAM } \\
\hline Loestion of & & LUS Wall WTRLE WRI & & & & BVEA BOTाUM & & \\
\hline 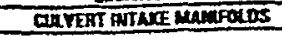 & & 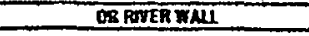 & & DNERT BEVATKOH & & gention & & Deringers \\
\hline 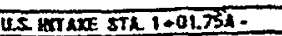 & & 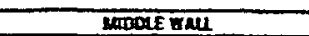 & & 390 & & 308 & & $\bar{\pi}$ \\
\hline \multicolumn{9}{|l|}{ DS DATAKE STA $0.26 .25 \mathrm{~A}$} \\
\hline & & & & & & & & \\
\hline ULS INTARE STR $0+B A$ SOA. & & Iuwoll & & 349 & & 368 & & 3 \\
\hline \multicolumn{9}{|l|}{ DS BraKCSTl $0050 \mathrm{~A}$} \\
\hline & & & & & - & & & \\
\hline 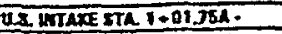 & & Frotwal & & 3 & & 325 & & $\overline{26}$ \\
\hline \multicolumn{9}{|l|}{ 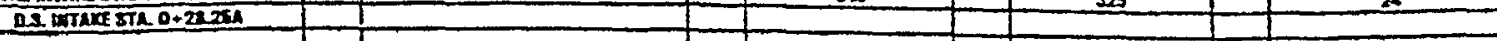 } \\
\hline & & & & & - & & & \\
\hline 列 & & & & & - & & & \\
\hline \multicolumn{9}{|c|}{ MARKLAND LOCKS AND DAM } \\
\hline & & & & & 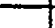 & & & \\
\hline Lochtion of & & LND WAL LODORE WLL & & & $m$ & EMYRERTITOA & & Deptit panow \\
\hline 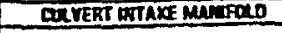 & & OR ARTER WHLI & & INVET REVATIOH & & 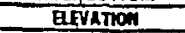 & & GrTaKes \\
\hline 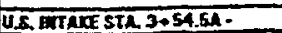 & & Moote wall & & $\$ 21$ & - & ata & & $\bar{T}$ \\
\hline \multirow{2}{*}{\multicolumn{9}{|c|}{ D. DITARESTh 2.75.5A }} \\
\hline & & & & & & & & \\
\hline AL. WTAR STh $3+25.5 \mathrm{~A}$ - & & Loperkis & & 483 & E & aid & & $T$ \\
\hline \multicolumn{9}{|l|}{ D.S. pITACa STA 2+20.5A } \\
\hline 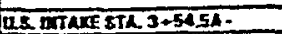 & & 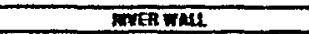 & & 421 & - & 100 & & $T$ \\
\hline \multicolumn{9}{|l|}{ DS.prrace sth 2+75.Sh } \\
\hline & & & & & - & & & \\
\hline & & & & & - & & & \\
\hline \multicolumn{9}{|c|}{ MCALPINE LOCKS AND DAM } \\
\hline & & & & & & & & \\
\hline thentio of & & Wo wall hoory w/L & & & & MIER DOTIOO & & EFTHBRDE \\
\hline 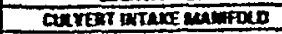 & & OR kiren will & & Dratarirm & & Gevation & & 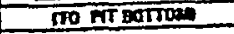 \\
\hline 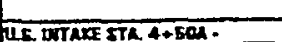 & & 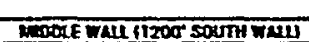 & & $3 x$ & 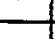 & mat & - & $\mathbf{F}$ \\
\hline \multicolumn{9}{|l|}{ DS GRAKESTh $s+\cos$} \\
\hline & & & & & & & & \\
\hline \multirow{2}{*}{\multicolumn{9}{|c|}{ 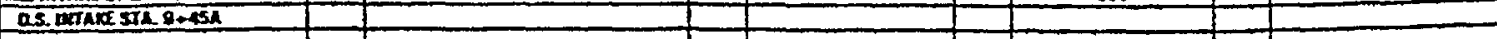 }} \\
\hline & & & & & & & & \\
\hline & & & & & $\mathrm{m}$ & & & \\
\hline \multirow{2}{*}{\multicolumn{9}{|c|}{ NEWBURGH LOCKS AND DAM }} \\
\hline & & & & & & & & \\
\hline 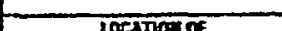 & & The & & & & & & \\
\hline 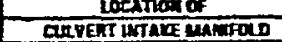 & & 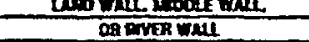 & & TVERT AFMATOM & 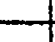 & Grentorton & - & 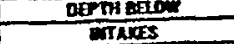 \\
\hline & & & & & & & & \\
\hline 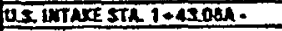 & & HODEREL & & 3055 & 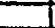 & 3203 & & $\underline{z}$ \\
\hline \multicolumn{9}{|l|}{ 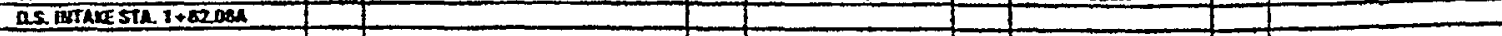 } \\
\hline US. DTALE STh 2-09A. & & tax wall & & $\sqrt{525}$ & - & $\sqrt{255}$ & & 5 \\
\hline as Grace $5 T h 2+\operatorname{man}$ & & & & & & & & \\
\hline 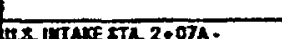 & & & & & & & & $\boldsymbol{x}$ \\
\hline 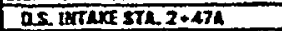 & & Sunthen & & 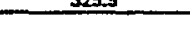 & -1 & 3235 & & - \\
\hline & & & & & & & & \\
\hline & & & & & - & & & \\
\hline UNIONTRMN I OCKS & n & nam & & & & & & \\
\hline 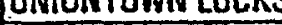 & WWU & UMIM & & & & & & \\
\hline Lochinem of & & 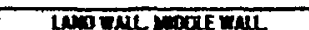 & & & & 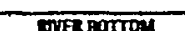 & & DEPTH DAOA \\
\hline 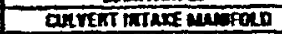 & & gosver waul & & mertarimon & & BEVATION & & mirates \\
\hline & & & & & & & & \\
\hline 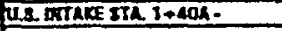 & & Noopt w whll & & 39.5 & & 306 & & 1.5 \\
\hline DS. INTAKESTh 10.RQRSA & & & & & & & & \\
\hline as ortace sTh $2+004$ - & & Dovo wau & & 307.3 & & 300 & & 1.5 \\
\hline $0 \leq$ GIRAESTL $2+934$ & & & & & & & & \\
\hline & & & & & & & & \\
\hline 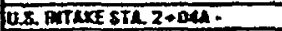 & & mrex whel & & 307.5 & ${ }^{2}$ & 300 & & 1.5 \\
\hline OS INTACE STL $2+91 \mathrm{~A}$ & & & & & & & & \\
\hline & & & & & & & & \\
\hline & & & & & & & & \\
\hline
\end{tabular}




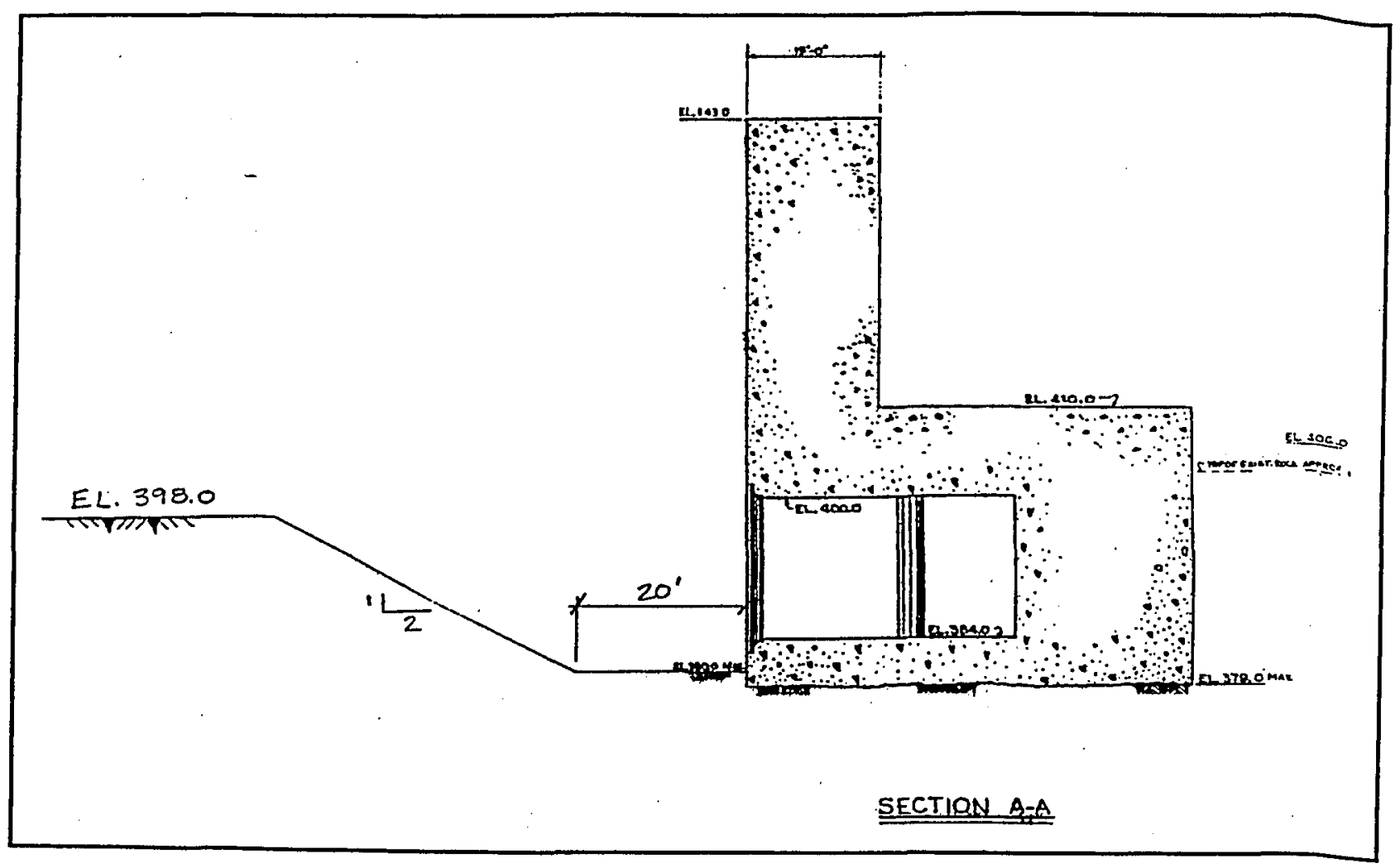




\section{APPENDIX $\mathrm{H}$}

\section{COLUMBIA RIVER POWER COMPLEX}

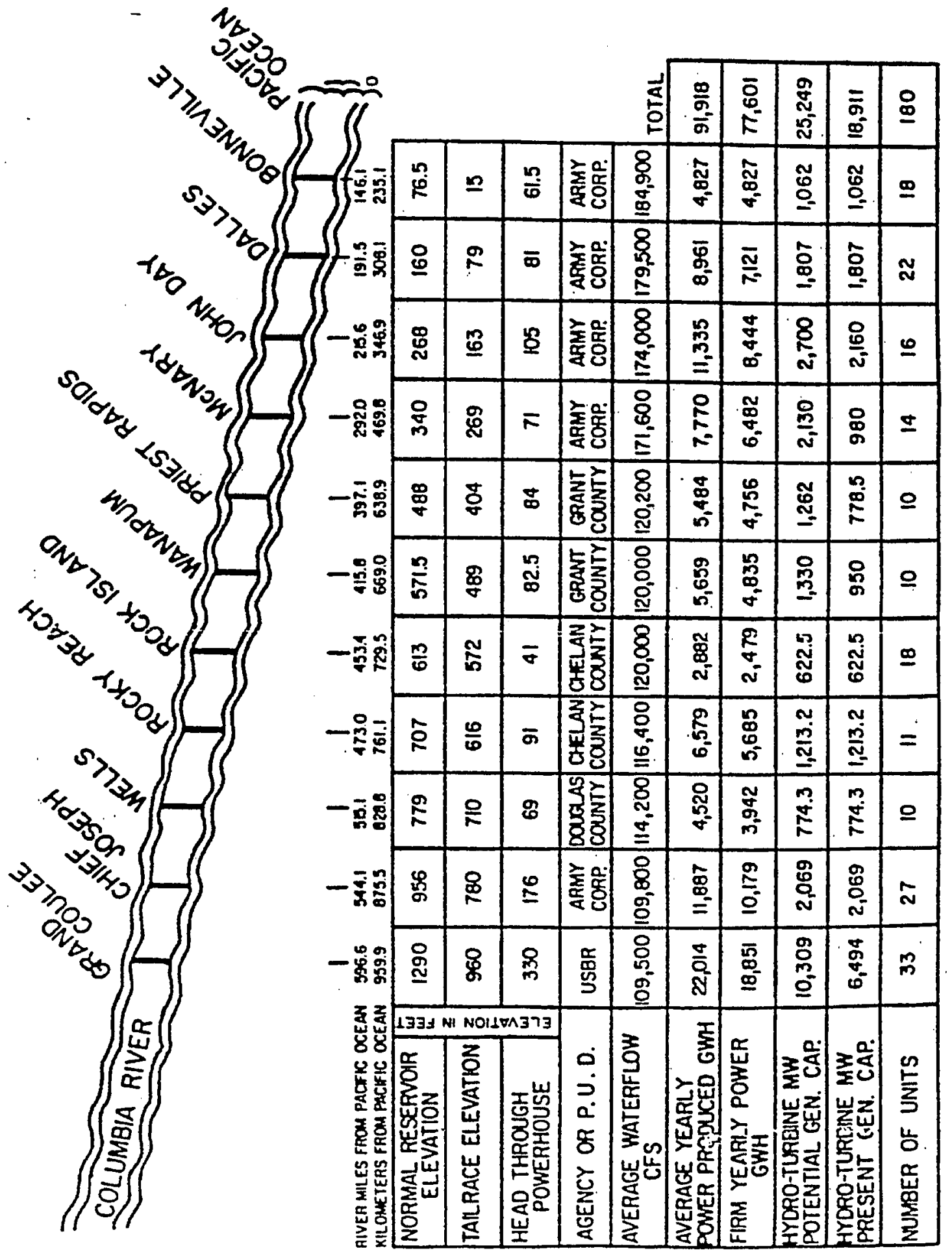




\section{APPENDIX I}

\section{SAN FRANCISCO BAY AREA OF OPERATION}

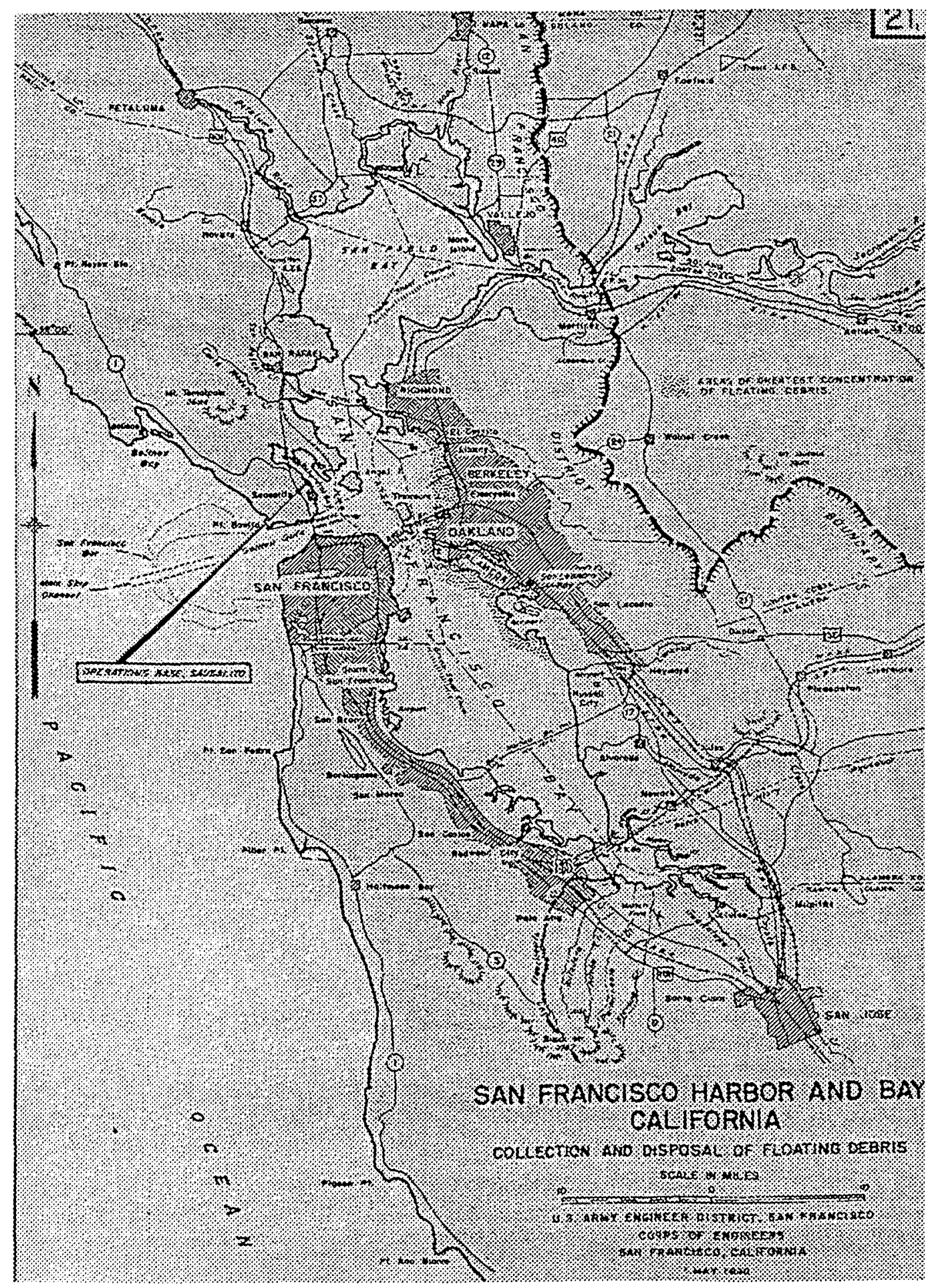




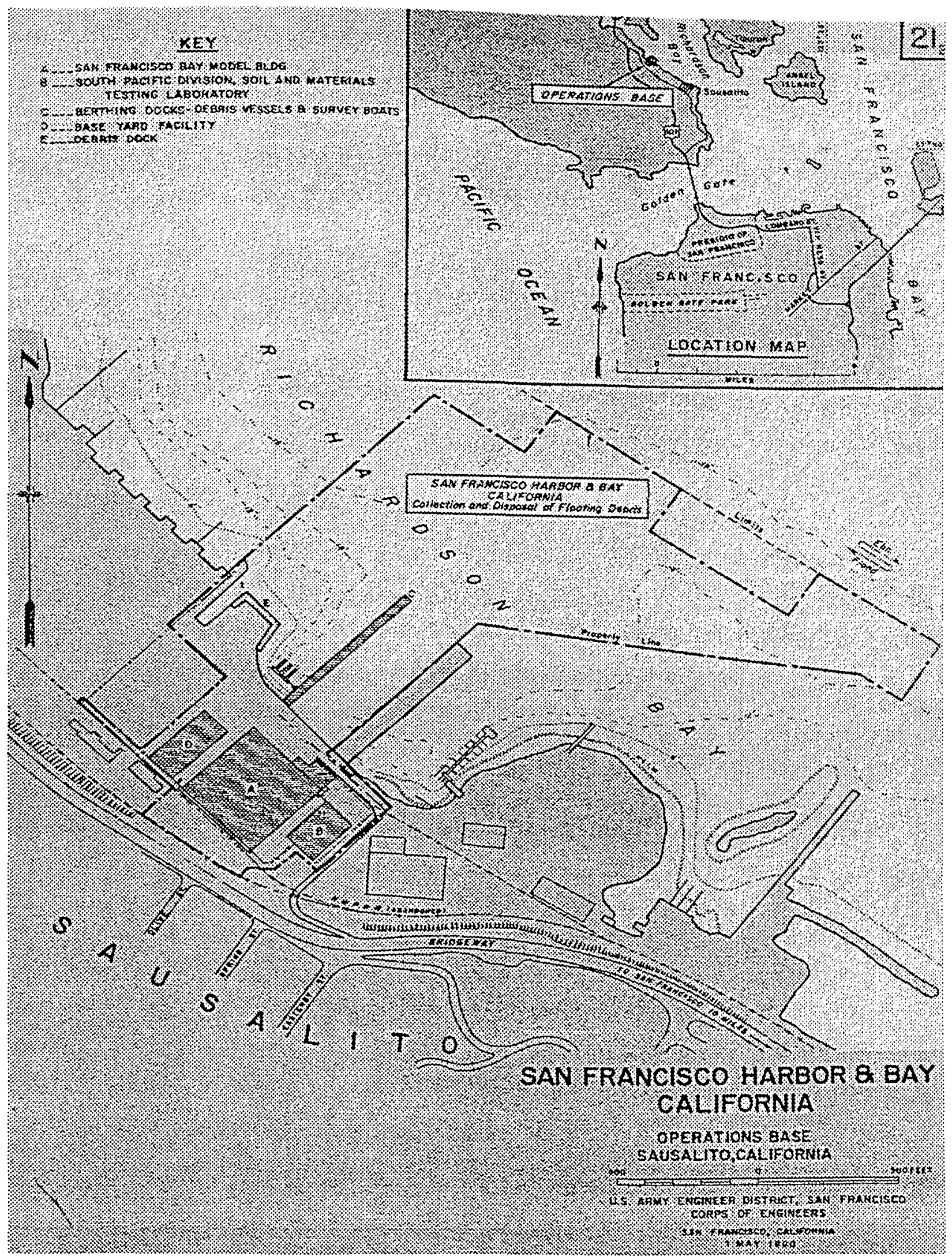




\section{APPENDIX J}

\section{DEBRIS BOAT TECHNICAL DESCRIPTION}

\subsection{PRINCIPAL DIMENSIONS OF "RACCOON"}

HULL IS A NAVY YSD Converted by CESPN

LENGTH OVERALL

96'-0"

LENGTH WATERLINE

$95^{\prime}-0^{\prime \prime}$

BEAM MOLDED

$30^{\prime}-0^{\prime \prime}$

WIDTH OF WELL FORWARD

$20^{\prime}-0^{\prime \prime}$

HULL DEPTH MOLDED

MAXIMUM OPERATING DRAFT

AFT

FWD

AFT

FWD

MAXIMUM OPERATING DRAFT

"NORMAL"

DRAFT

$5^{\prime}-6 "$

"NORMAL"

DRAFT

3'-0"

MAIN ENGINES

CAT D 353

SHAFT HORSEPOWER @ RPM.

TRANSMISSION:

TWIN DISC MG 530 M OMEGA

REDUCTION RATIO

3.13 TO 1

FULL LOAD SPEED RPM

PROPELLER DIAMETER

60 INCHES

PROP. TIP SPEED @ 1300 ENG RPM FEET/ MINUTE

6524

OPERATING AREA:

SAN FRANCISCO BAY

USUAL WIND CONDITIONS

CALM TO 30 KTS.

USUAL SEA CONDITIONS

CALM TO 4 FOOT WAVES.

REFER TO THE PROJECT DEFINITION MEMO (SECTION 13) FOR ADDITIONAL DETAILS 


\subsection{OPERATING LIMITS OF EXISTING VESSEL}

Operation above 1200 RPM even in calm seas results is heavy propeller induced vibration in the whole pilothouse structure.

Operation in 4 foot swells at speed above 5-6 knots results in heavy slamming due to impacts of the shallow draft flat bottom hull, and flat bottom sections through the catamaran bows.

Operation with the Debris net raised clear of the water reduces the hull resistance, but increases the height of the pressure swell trapped between the catamaran bows. The combination of 3-4 foot waves and this pressure wave "hum" puts lots of water on deck at the aft end of the wall.

The platform stability is presently limited by the 30 foot beam; added beam would increase stability and also increase pounding of the shallow wide flat bottom hull form.

\subsection{OBSERVATIONS DURING OPERATIONS}

The net design and construction and the nature of the Debris collected is not going to change.

AT LOW SPEEDS 0 TO 5 KTS. - No limits to operation. Some slamming if operating in 3-4 foot seas.

AT MEDIUM SPEEDS 5 TO 8 KTS. - Flow of water through the Debris and Debris basket becomes turbulent and aerated. The $5 "$ pipe basket spreaders with chain link and wire mesh fabric plus the pipe support frame and trapped debris combines to produce maximum turbulence and aeration. The forward velocity drives this aerated turbulent water under the hull between the catamaran bows, which act as end plates; and the wide flat bottom hull funnels the bad flow straight aft to the propeller tunnels.

The vessel was re-powered to replace overage engines, and to increase the maneuvering power and speed. The original tunnel was designed for 40 inch diameter propellers. The new propeller diameter is 60 inches, of which 18 inches extends below the baseline. The tunnels were not modified. MDC has no record of changes in the tunnel area, and the bottom structure appears to be unchanged from the as-built condition. 
AT HIGH SPEED 8 TO 10 KTS. - In calm water less than 3 foot waves, Propeller induced vibration causes the pilothouse to shake so much that the operators are afraid of risking structural damage. The Propeller tip speed at 1300 Engine RPM is 6524 feet per minute. The propeller load/ engine condition is such that 1300 RPM is the highest possible RPM.

In 3 to 4 foot waves, the operators must pull back the throttles to reduce propeller induced vibration, and to reduce hull slamming forward when the 3 foot draft flat bottom encounters 4 foot waves, and to control waves breaking on deck. The water level in the well rises as the hull speed increases and the pressure wave combines with the wave action, which puts nearly every wave top on the deck.

The Maximum transit speed is achieved with a draft forward of 2'-6" to $3^{\prime} 0^{\prime \prime}$ with the Debris Net hoisted clear of the water.

If the vessel is ballasted forward to increase the bow draft to $3^{\prime}-6^{\prime \prime}$ to $4^{\prime} 0^{\prime \prime}$, the pressure wave increases in height and the number of waves and volume of water coming aboard increases. The slamming forward is reduced but the wave forces on the bows and the propeller vibration aft also increases.

\subsection{DESIRED RESULTS FROM NEW DESIGN/NEW VESSEL}

\section{CREATE A NEW VESSEL DESIGN WITH MINIMUM EFFECT OF:}

- Aeration of water flow to the propellers.

- Pounding (Slamming) of shallow flat bottom.

- Reducing the amount of water breaking on the deck. 


\section{APPENDIX K \\ PHOTOGRAPHS}

\section{San Francisco District}

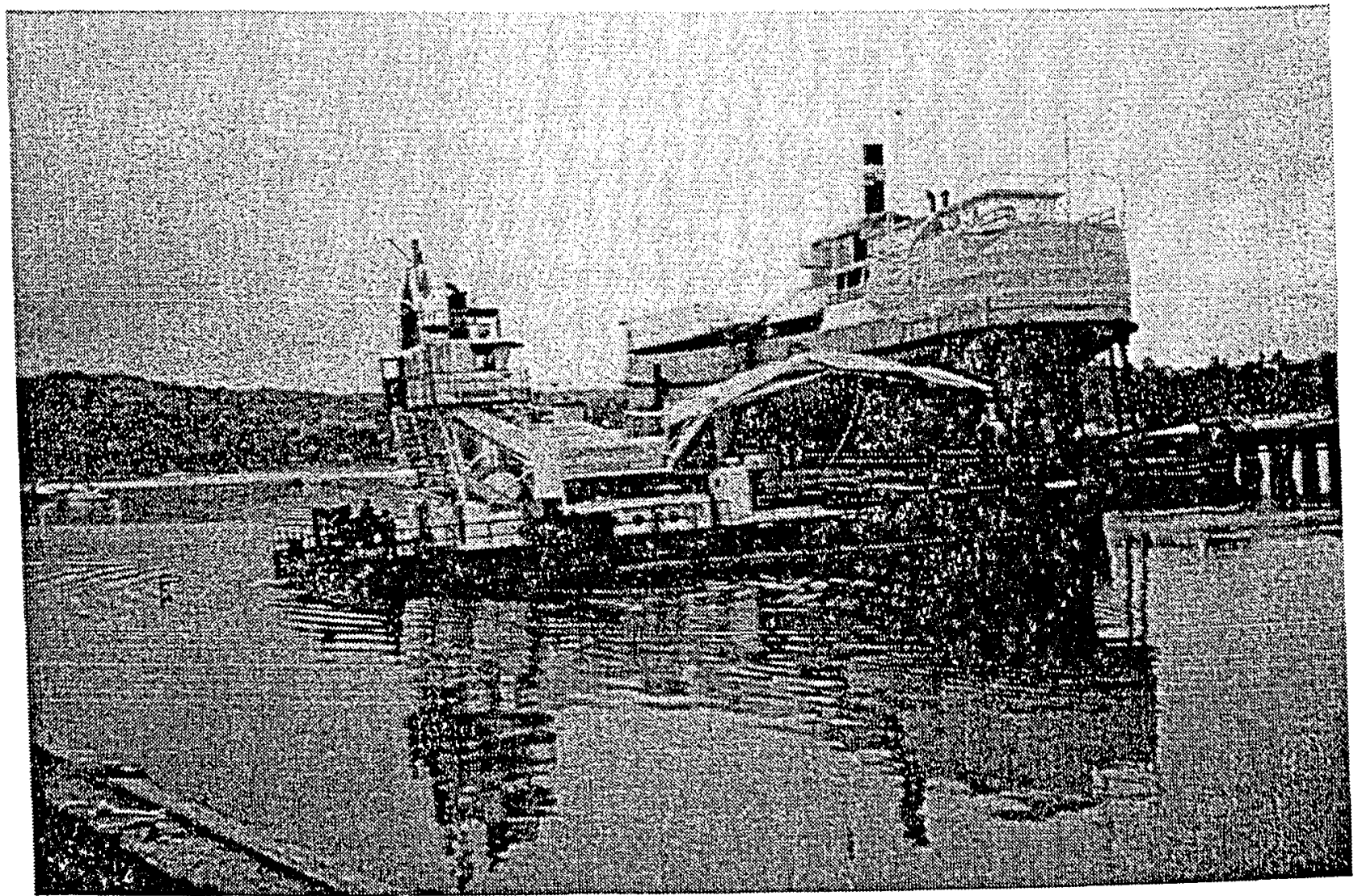

Raccoon Debris Management Vessel 


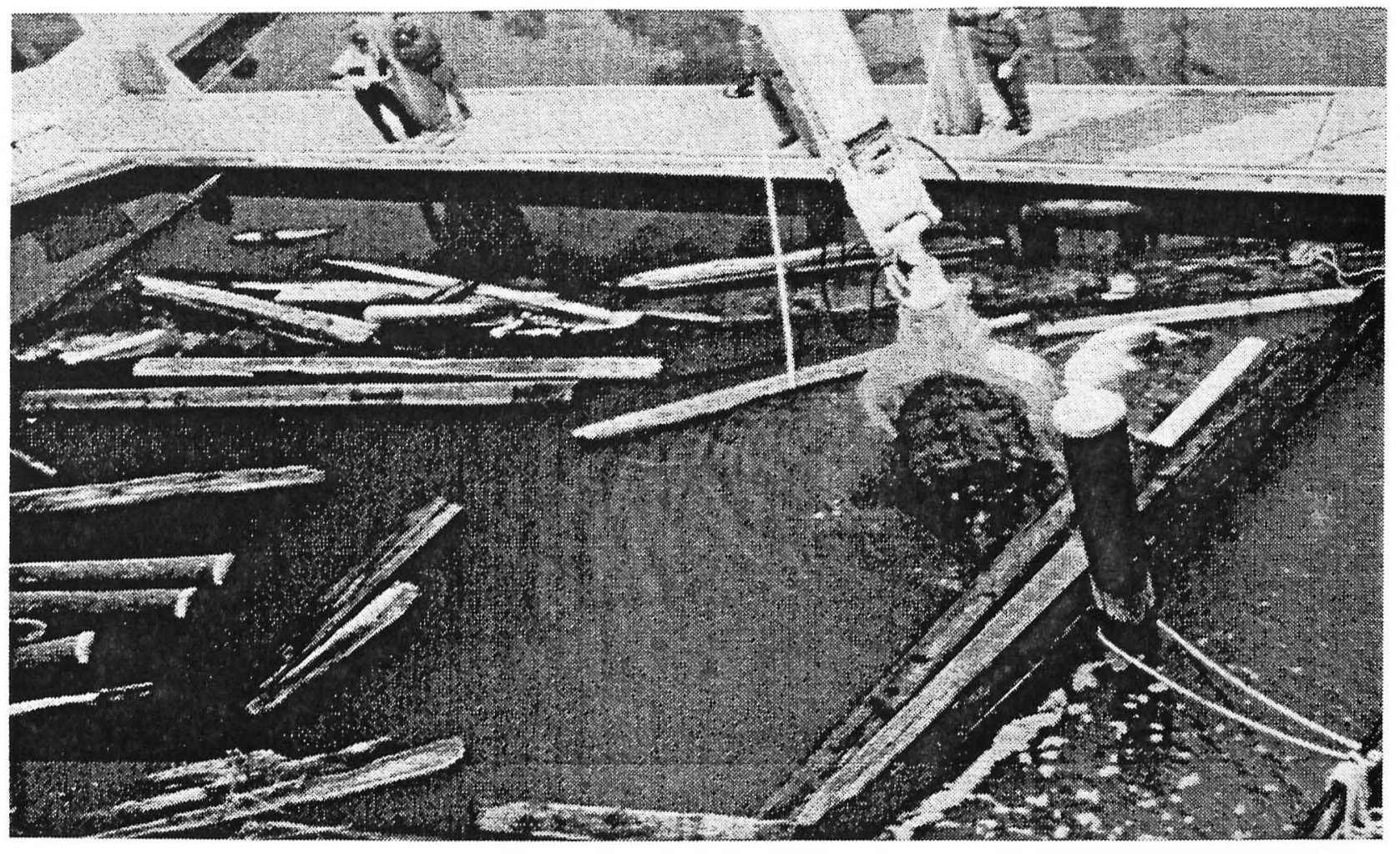

\section{Raccoon Crane and Grapple Removing Debris}




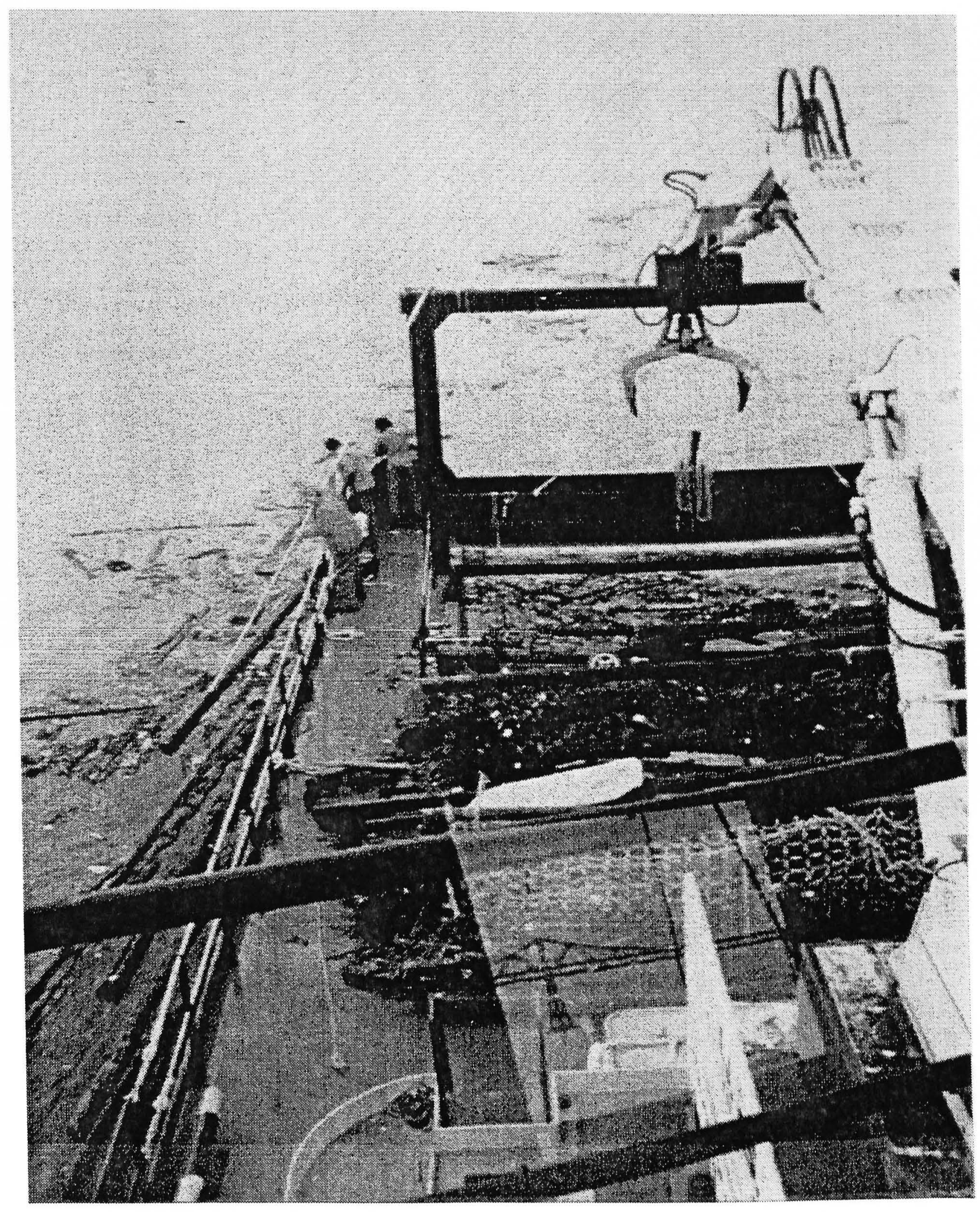

Raccoon Nets Filled with Debris 


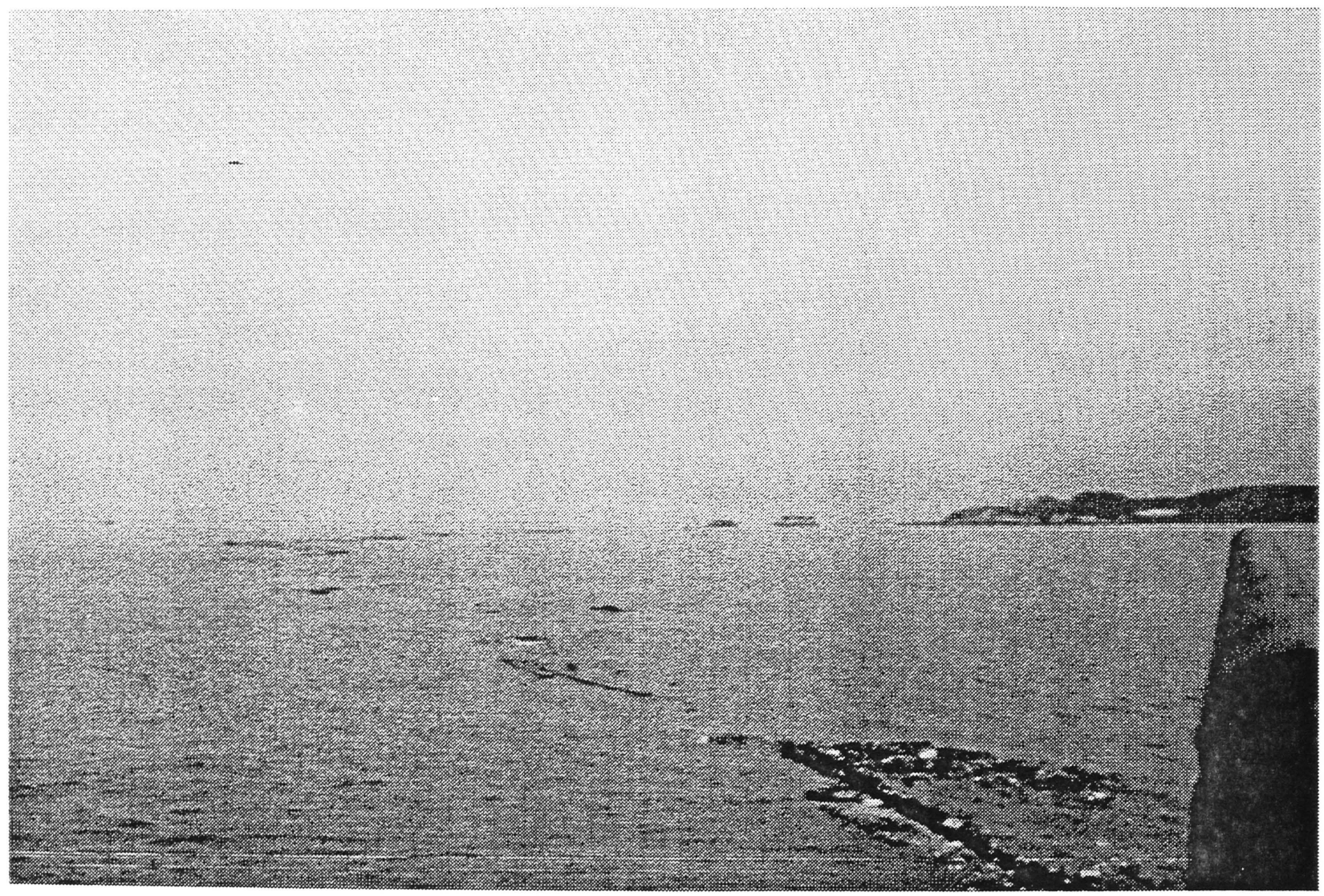

Debris Riff in Shipping Lane of San Francisco Bay 
$\underline{\text { Portland District }}$

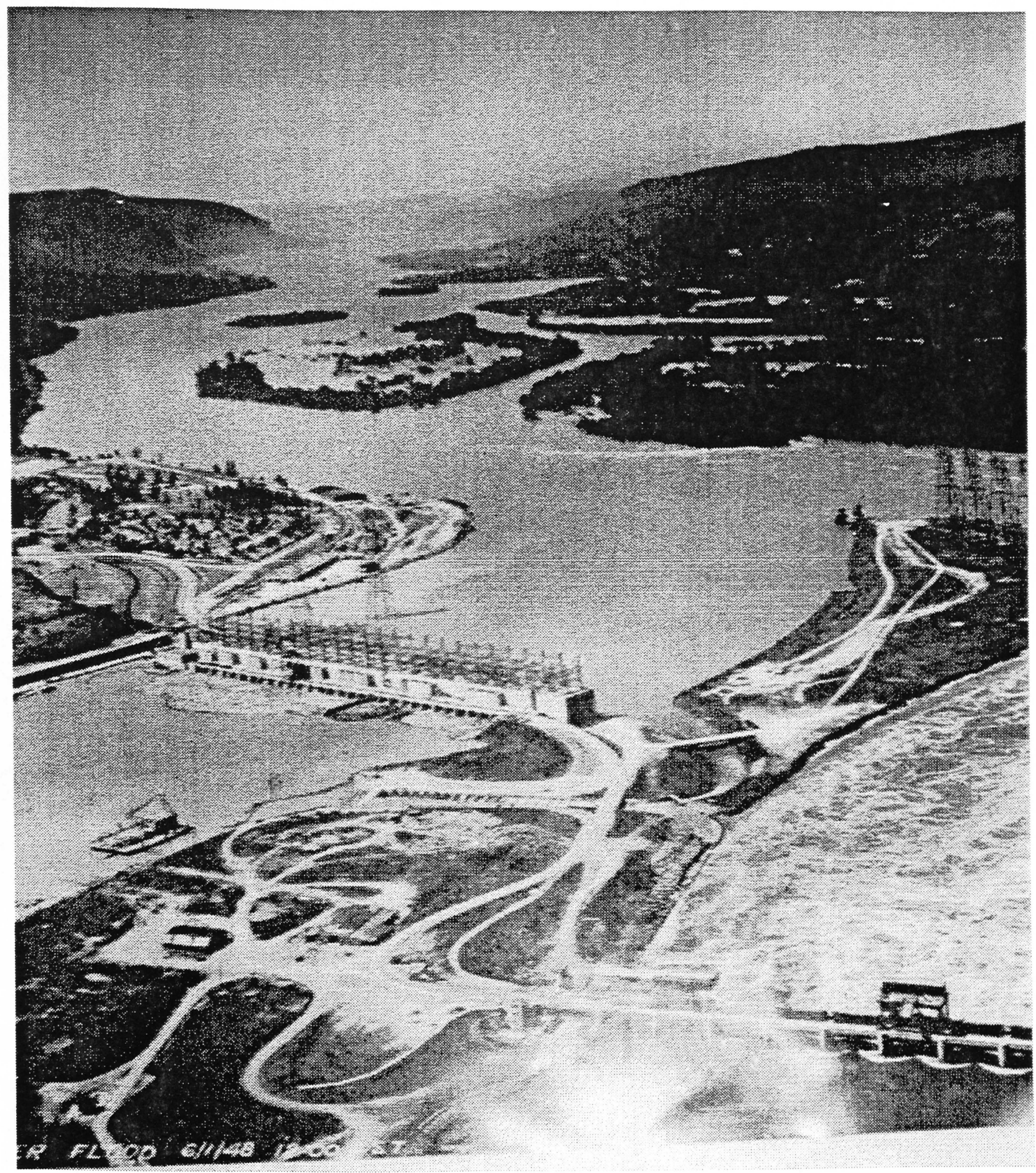

Bonneville Powerhouse No. 1 with debris jam in 1948 


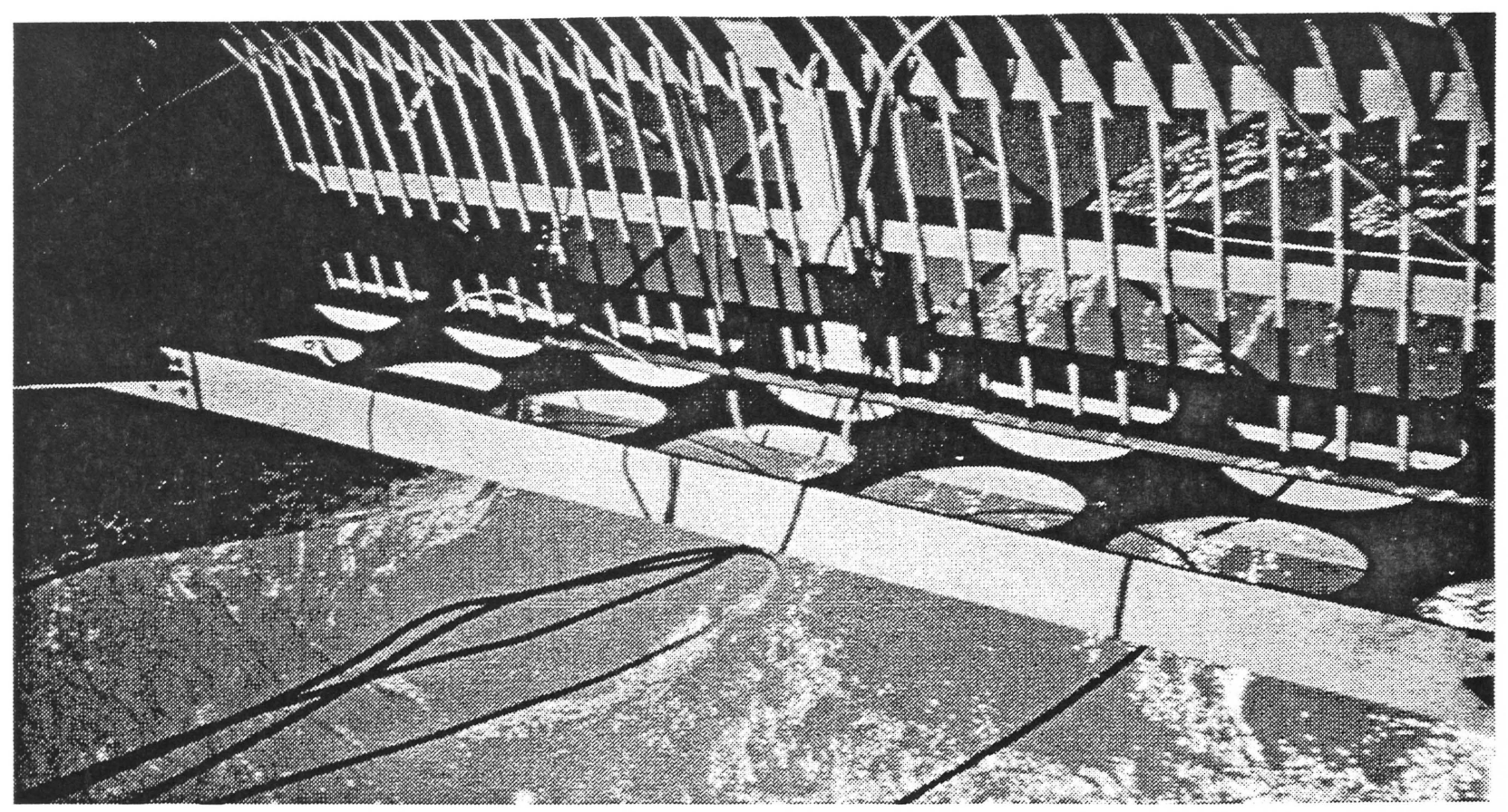

Debris Grates at Powerhouse No. 1 Intake adjacent to Sluiceway, Bonneville Dam

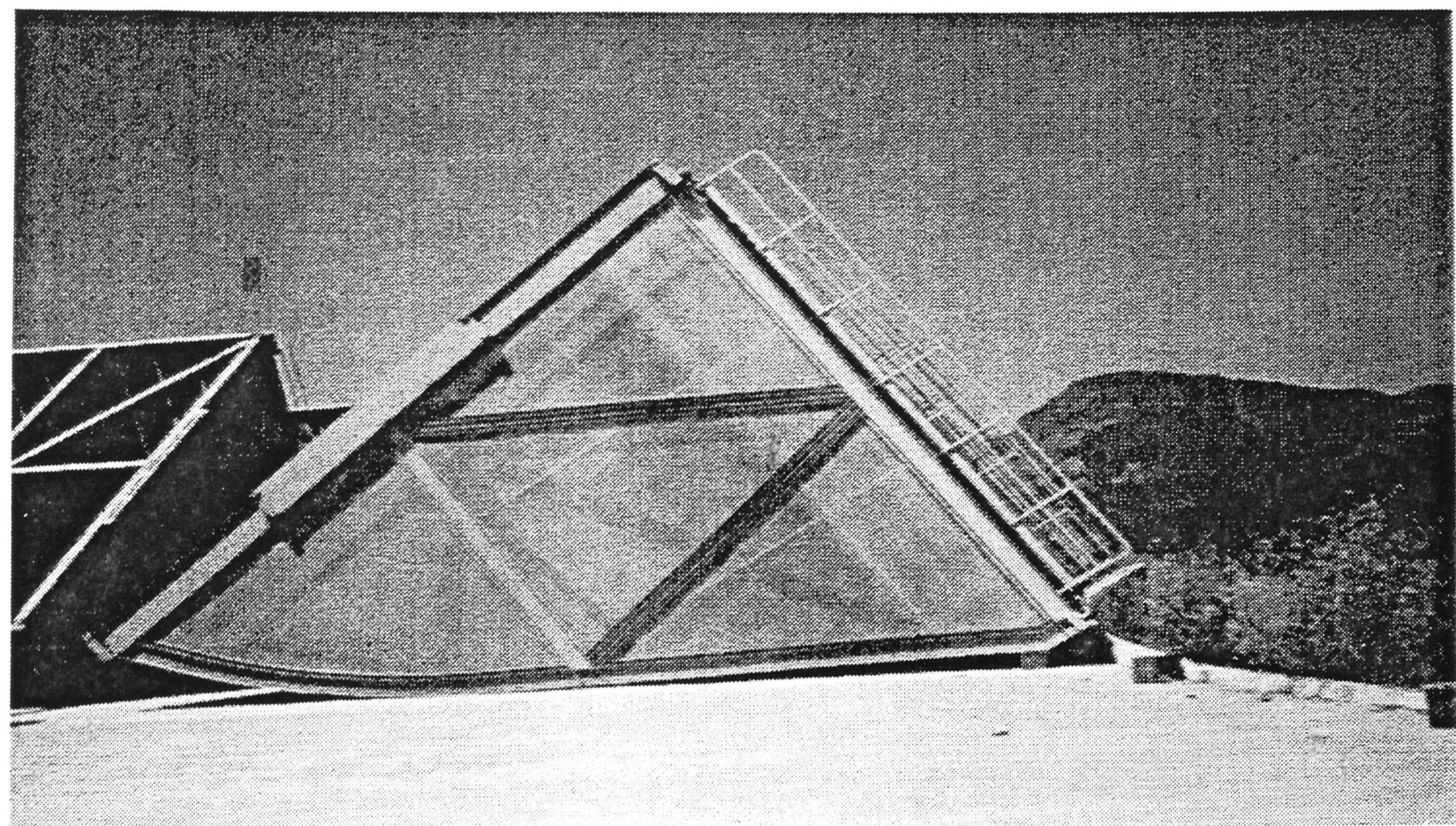

Intake Screens for Powerhouse No. 2, Bonneville Dam 


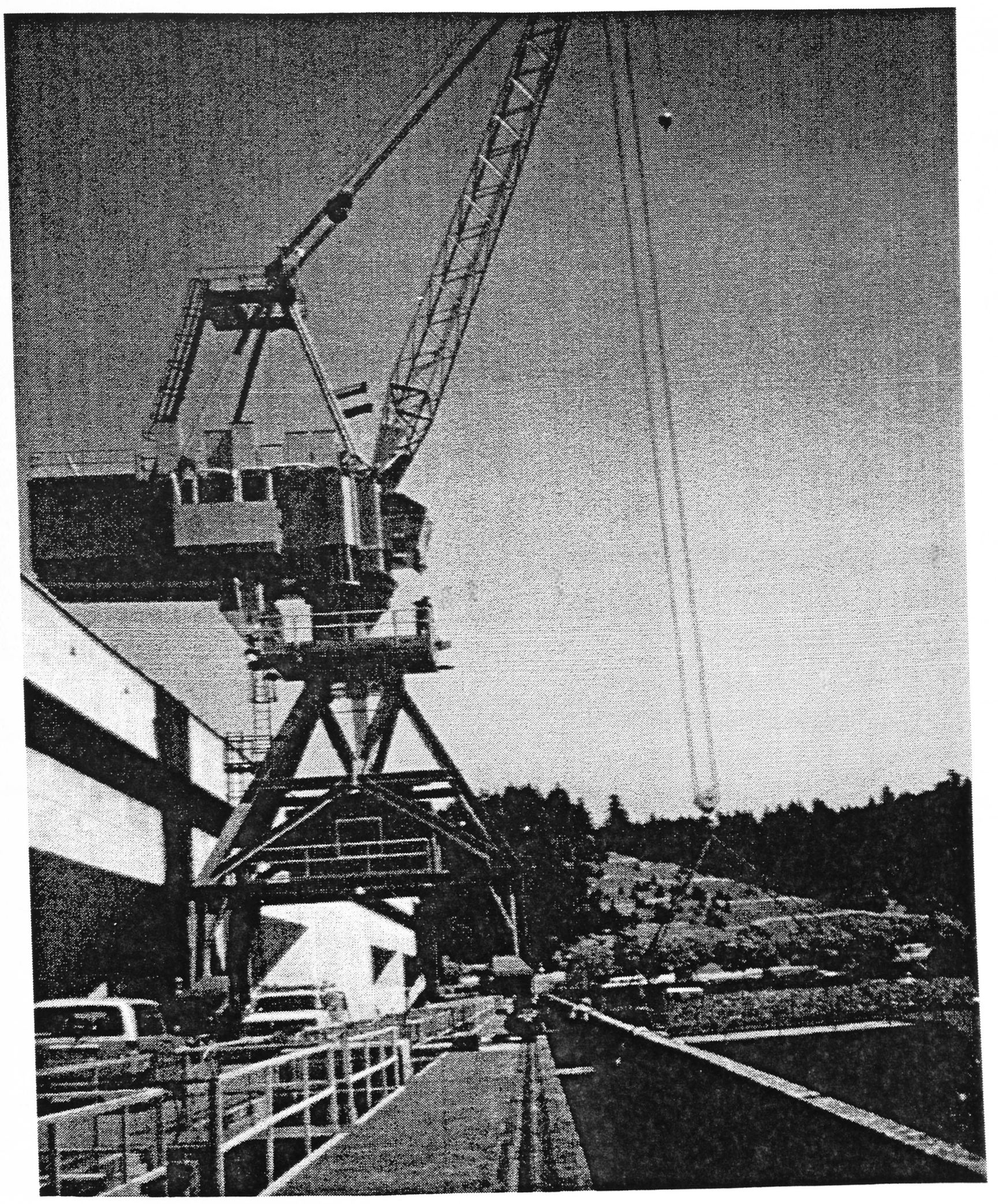

Gantry crane used to place intake screens at powerhouse No. 2, Bonneville Dam 


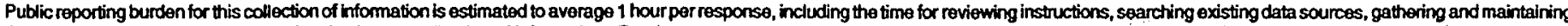

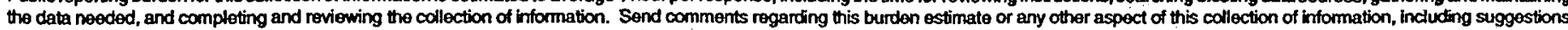

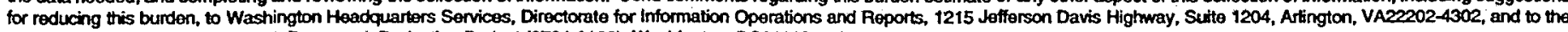
Office of Management and Budget, Paperwork Reduction Project (0704-0188), Washington, DC20503.

\begin{tabular}{|l|l}
\hline 1.AGENCY USE ONLY (Leave blank) & 2.REPORT DATE
\end{tabular}

December 1997

3.REPORT TYPE AND DATES COVERED

Final report

\section{TITLE AND SUBTTITE}

Debris Control at Hydraulic Structures in Selected Areas of the United States and Europe

6.AUTHOR(S)

N. Wallerstein, C. R. Thome, S. R. Abt

\section{PERFORMING ORGANIZATION NAME(S) AND ADDRESS(ES)}

Department of Geography, University of Nottingham, Nottingham, England

Engineering Research Center, Colorado State University, Ft. Collins, CO

8.PERFORMING ORGANIZATION REPORT NUMBER

\section{SPONSORINGMONITORING AGENCY NAME(S) AND ADDRESS(ES)}

U.S. Army Research Development and Standardization Group-UK, London, England; U.S. Army Engineer Waterways Experiment Station 3909 Halls Ferry Road, Vicksburg, MS 39180-6199
5.FUNDING NUMBERS

\section{SUPPLEMENTARY NOTES}

Available from National Technical Information Service, 5285 Port Royal Road, Springfield, VA 22161.

12a.DISTRIBUTIONAVAILABIUTY STATEMENT

Approved for public release; distribution is unlimited.
12b.DISTRIBUTION CODE

\section{ABSTRACT (Maximum 200 words)}

Floating debris obstruction is a problem at many run-of-river structures including navigation locks, hydro-electric and thermal-electric power plants and dam spillways. Previous research suggests a sound understanding of debris sources would id with developing more cost effective debris control methods. This report reviews current debris management technologies e.aployed at various run-of-river structures in Europe and the United States of America. The information reported has been ontained through field visits and from discussions with engineers and plant operators. Relevant published research work on debris control mechanisms, including trash rack design problems, raking equipment, and spillway design is also reviewed. European research centers visited were Delft Hydraulics in the Netherlands, the Hydraulics Laboratory at the Technical University of Munich, Germany, and the Institute of Hydraulics, Hydrology and Glaciology at the Technical University of Zurich, Switzerland. The U.S. field visits were carried out in the Huntington, Vicksburg, St. Louis, Portland, and San Francisco Corps of Engineer Districts. The control technologies are summarized, and state-of-the-art design procedures and best practice management recommendations for debris control are outlined for each class of structure that may experience debris-related problems.

\begin{tabular}{|c|c|c|}
\hline \multicolumn{3}{|l|}{ 14.SUBJECT TERMS } \\
\hline Debris & Lock and Dams & Retention \\
\hline Diversion & Power plant & Spillways \\
\hline High Head Dams & Reservoirs & Trash Racks \\
\hline $\begin{array}{l}\text { 17.SECURITY CLASSIFICATION } \\
\text { OF REPORT }\end{array}$ & $\begin{array}{l}\text { 18.SECURITY CLASSIFICATION } \\
\text { OF THIS PAGE }\end{array}$ & $\begin{array}{l}\text { 19.SECURITY CLASSIFICATION } \\
\text { OF ABSTRACT }\end{array}$ \\
\hline UNCLASSIFIED & UNCLASSIFIED & \\
\hline
\end{tabular}

